\title{
Potential of the predatory pentatomid Eocanthecona furcellata (Wolff) as a biocontrol agent on American bollworm in cotton in Myanmar
}

\author{
Doctoral Dissertation \\ to obtain the Ph. D. degree \\ in the Faculty of Agricultural Sciences, \\ Georg-August University Göttingen, Germany \\ Presented by \\ Khin Thein Nyunt \\ born in Mawlamyine, Myanmar
}

Göttingen, April 2008 
D7

1. Name of referee:

Prof. Dr.Stefan Vidal

2. Name of co-referee:

Prof. Dr. Hans Michael Poehling

Date of dissertation: $3^{\text {rd }}$ April 2008 
This thesis is dedicated to my mother Daw Tin May, sisters $\mathcal{T}$ in $\mathcal{T}$ in $\mathcal{N}$ yunt, Kfin May Nyunt \& fer fusband Alan $\mathcal{P o}_{0}$ 


\section{Acknowledgements}

My profound thanks and indebtedness are due to Prof. Dr. Stafen Vidal, my "Doktorvater", whohas given this word its real meaning, through his guidance, encouragement, inspiration and positive criticism over the entire work.

I would like to thank Prof. Dr. Hans Michael Poehling for kindly using his valuable time as co-referent for this dissertation and, Prof. Dr. Teja Tscharntke and PD Dr. Martin Worbes for his interest to be an external examiner.

Grateful thanks are also express to Dr. Bernd Ulber, Dr. Dereje Dugassa-Gobena and Dr. Joachim Möser for their helpful and constructive suggestions, critical comments and assistance during this study. I also like to thank Mrs. Dorothea Mennerich, Mrs. Angelika Metje who provided the basic material for my research: American bollworm, Diamondback moth, cotton, chickpea, wild cabbage, corn and tomato plants. My sincere thanks go to Dr. Dereje Dugassa-Gobena for reviewing the manuscript and his advices.

I wish also to accord a special debt of gratitude to all my colleagues in the Entomology Section, Department of Crop Science, for the unforgettable friendly research environment they have created and the cooperative spirits they have shown at each step of the research and writing of the thesis.

My thanks are extended to Daw Nu Nu Yi and Daw Nyo Nyo from Myanma Agricultral Service, Daw May Than Yee and colleagues from Shwe Daung Cotton Research Farm, Daw Nywe Nywe Yin from Department of Agricultural Research for collecting and providing of Eocanthecona furcellata eggs used to initiate the stock culture for the present research.

This research could have never been done without the generous financial support from Gottlied Daimler und Karl Benz foundation.

Finally, special thanks and gratitude are due to my mother Daw Tin May, my elder sister Khin May Nyunt and her husband Alan Po, my younger sister Tin Tin Nyunt, in addition to their endless support and encouragement during my study. 
CONTENTS

GENERAL INTRODUCTION

CHAPTER 1

PREY PREFERENCE AND PREDATION EFFICACY OF Eocanthecona furcellata WOLFF (HEMIPTERA: PENTATOMIDAE) ON Helicoverpa armigera HÜBNER LARVAE FROM DIFFERENT HOST PLANTS

ABSTRACT

INTRODUCTION

MATERIAL AND METHODS

RESULT

DISSCUSION

REFERENCE

CHAPTER 2

PREY CONSUMPTION AND FITNESS OF Eocanthecona furcellata WOLFF (HEMIPTERA: PENTATOMIDAE) ON DIAMONDBACK MOTH LARVAE AT DIFFERENT TEMPERATURE REGIMES AND PREY DENSITY

ABSTRACT

INTRODUCTION

MATERIAL AND METHODS

RESULT

DISSCUSION

REFERENCE

CHAPTER 3

PREY SEARCHING AND FEEDING BEHAVIOR OF Eocanthecona furcellata WOLFF (HEMIPTERA: PENTATOMIDAE ON DIFFERENT PREY ITEMS, HOST PLANT SPECIES AND PLANT STATUS

ABSTRACT

INTRODUCTION 
$\begin{array}{ll}\text { MATERIAL AND METHODS } & 57\end{array}$

$\begin{array}{ll}\text { RESULT } & 60\end{array}$

$\begin{array}{ll}\text { DISSCUSION } & 69\end{array}$

$\begin{array}{ll}\text { REFERENCE } & 70\end{array}$

$\begin{array}{ll}\text { GENERAL DISCUSSION } & 76\end{array}$

$\begin{array}{lc}\text { CONCLUSION } & 83\end{array}$

$\begin{array}{lc}\text { REFERENCES } & 84\end{array}$

$\begin{array}{lr}\text { SUMMARY } & 97\end{array}$

The following posters in the appendix are part of this thesis:

1. Potential for Biocontrol of Diamondback moth in Myanmar by using a predatory bug

2. Predatory potential of the Pentatomid stink bug Eocanthecona furcellata at different temperature regimes

3. Predatory efficacy of Eocanthecona furcellata on Helicoverpa armigera larvae reared on different host plants 


\section{GENERAL INTRODUCTION}

Myanmar is one of the developing countries, where economy is mainly based on the agriculture. Cotton is one of the main crops for foreign exchange earning and self-sufficiency in Myanmar. In 1952, cotton project was planned and the new technology was introduced by the Government to improve the quality and quantity of cotton production in Myanmar. Early since then native cultivars, short staple cotton (Gossypium arboreum) Mahlaing 3 and Mahlaing 5 were grown for commercial cultivation (Myintzu, 1974). In 1953-1954, the Agricultural and Rural Department Corporation introduced medium staple cotton (Gossypium hirsutum) cultivars (MCSE, 1999). In 1980-81 seasons, Myanmar was ranked at No. 36 of the world cotton producers (Frisbie, 1983). Accordingly, cotton area, productivity and production significantly progressed during past forty years but Myanmar's current yield levels are admittedly low, which constitute only one third of world average (Pye Tin, 2003).

Local varieties of cotton (G. arboreum) are grown for their low susceptibility to pests and pesticides had to be applied rarely. However, medium staple cotton ( $G$. hirsutum) is prone to infestation of sucking pests in the early stages and of bollworm from the initiation stage of squares up to maturing of cotton bolls (MCSE, 1999). According to the report of Myanma Cotton and Sericulture Enterprise (MCSE) in 1999, American bollworm is recorded as a major cotton pest of economic importance.

American bollworm (Helicoverpa armigera Hübner) which is found in all agricultural regions of Myanmar, is the most severe pest of cotton, chickpea, maize, sorghum, pigeon pea, potato, tomato, tobacco respectively (Morris and Waterhouse, 2001). Although chemical insecticides were widely applied to control this pest, reduction in the yield of seed cotton was as high as 90 percent in some cases (Myat Htwe and Mya Maung, 1992). Misuse or overuse of insecticides may results in the reduction or even eradication of predators and parasitoids in the cotton fields. Although the damage could kept low by the use of insecticides, it may Emergent impacts of multiple predators on prey unknot economically feasible for cotton growers. On 
other hand, environmental pollution may become a great problem in the long run. To overcome these problems, it is desirable to use biological control whenever feasible. Based on previous study (Khin, 2001) several effective predators can be found in the agroecosystem of Myanmar. Among them, the predatory bug Eocanthecona furcellata Wolff (Hemiptera: Pentatomidae) could be regarded as a potential larval predator for the whole cotton growing season.

The predatory bug Eocanthecona furcellata Wolff (Hemiptera: Pentatomidae) is found especially in cotton, chickpea and vegetable fields and has been found preying on larvae of leaf worm, spotted bollworm and American bollworm in Myanmar (Gillham, 1980; Nu Nu Yi and Win Kyi, 2000, and Khin, 2001). E. furcellata has been also reported from Southeast Asia, Japan, India, and Taiwan, and has been preying on Lepidopteran, Coleopteran and Heteropteran insects (Ahmad, 1996; Chu, 1975; Chang, 2002; Jakhmola, 1983; Prasad et. al., 1983). This predator is regarded to be a generalist, however, data on his efficacy or on prey preferences are scattered. Thus an evaluation of this predator under laboratory conditions is regarded necessary to understand its potential use as a biological control agent under field conditions.

The present work aimed, therefore, to observe the ecology and biology of Eocanthecona furcellata by:

1. Prey preferences and predation efficacy of Eocanthecona furcellata on Helicoverpa armigera Hübner larvae from different host plants

1) The effect of host plants on the oviposition preference of $H$. armigera

2) The effect of host plants on the performance of $H$. armigera larvae

3) Predation efficiency of E. furcellata on Helicoverpa armigera (Hübner) reared on different host plants (Cabbage, Cotton, Chickpea, Tomato plant) and on artificial diet 
4) Prey selection of EO on wrapped American Bollworm Helicoverpa armigera (ABW) reared on different host plants (Cabbage, Cotton and Chickpea)

2. Prey consumption and fitness of Eocanthecona furcellata Wolff (Hemiptera: Pentatomidae) on Diamondback moth larvae at different temperature regimes and prey density

1) Evaluating the effect of three constant temperatures $\left(25^{\circ} \mathrm{C}, 30^{\circ} \mathrm{C}\right.$ and $\left.35^{\circ} \mathrm{C}\right)$ and eight prey densities (1,2,3,4,5,6,8,and 10 Diamondback moth larvae) on the development, prey consumption and predation of $E$. furcellata

2) Effect of high temperatures $\left(15^{\circ} \mathrm{C}, 20^{\circ} \mathrm{C} 37^{\circ} \mathrm{C}\right.$ and $\left.40^{\circ} \mathrm{C}\right)$ on the development, mortality and prey consumption of the predatory bug Eocanthecona furcellata

3. Prey searching and feeding behavior of Eocanthecona furcellata Wolff (Hemiptera: Pentatomidae on different prey items, host plant species and plant status

1) Effect of different preys (American bollworm and Diamondback moth)

2) Effect of different host plants (cotton and wild cabbage)

3) Effect of different conditions (normal plant, wounded plant, and insect infected plant)

4) Observing of host choice behavior of Eocanthecona furcellata (EO) towards American bollworm (ABW) and Diamondback moth (DBM) larvae in Y-olfactometer 


\title{
CHAPTER 1
}

\section{Prey preference and predation efficacy of Eocanthecona furcellata Wolff (Hemiptera: Pentatomidae) on Helicoverpa armigera Hübner larvae from different host plants}

\begin{abstract}
American bollworm (Helicoverpa armigera Hübner) is one of the most severe pests of economic important crops and even using chemical control, up to 90 percent yield loss was found in seed cotton in Myanmar.

The predatory pentatomid bug Eocanthecona furcellata (Wolff) is regarded a potential biological control agent against lepidopteran pests in Southeast Asia. However, no studies are available on the predation efficacy of Eocanthecona furcellata on Helicoverpa armigera larvae feeding on different host plants. This information is regarded important with regard to releasing $E$. furcellata as a biocontrol agent for control of $H$. armigera in Myanmar.
\end{abstract}

Therefore, we investigated (1) the effect of host plants on the oviposition preference of $H$. armigera; (2) the effect of host plants on the performance of $H$. armigera larvae; (3) prey selection and predation of $E$. furcellata on the polyphygous pest American bollworm reared on cotton, chickpea, tomato, wild cabbage plant, and artificial diet; and (4) Prey reference of Eocanthecona furcellata on wrapped American Bollworm Helicoverpa armigera reared on different host plants (cabbage, cotton and chickpea).

H. armigera preferred to lay eggs on chickpea plants as compared to tomato, cotton and wild cabbage plants. Predation efficacy of E. furcellata was tested with American Bollworm from four different host plants (cabbage, cotton, chickpea and tomato). Significantly more E. furcellata (30-60 \%) directly approached towards cotton plants and preyed on $H$. armigera larvae. When $H$. armigera larvae and their 
faeces were wrapped with Para film ' $M$ ', the prey selecting efficacy was reduced up to $20-40 \%$.

Base on these data we suggest that it is possible to release the predatory bug Eocanthecona furcellata in cotton fields as a biocontrol agent for controlling Helicoverpa armigera in Myanmar; the impact of the surrounding vegetation on releasing the predator in the fields is discussed.

Keywords: American bollworm, Biological control, Eocanthecona furcellata, Diamondback Moth, Host plants, Myanmar, Predation efficacy

\section{INTRODUCTION}

In Myanmar, American bollworm is the most severe pest of economically important crops including cotton, chickpea, pigeon pea, pea and beans; the pest is found in all agricultural regions of Myanmar (Morris and Waterhouse, 2001). The American bollworm (Helicoverpa armigera Hübner) is known as a widespread polyphagous pest, with high mobility and fecundity (Hardwick, 1965; Fitt, 1989 and King, 1994). The larvae feed on a wide range of food, fiber, oil and fodder crops, as well as on many horticultural and ornamental plants (Pearson, 1958, Zalucki et.al., 1986 and Fitt, 1989). Reed and Pawar (1982) reported Helicoverpa armigera damaging 60 cultivated plant species and 67 other plant species.

Survival of the larvae is dependent on appropriate host selection by females (Fitt \& Boyan, 1991 and Fitt, 1991) because host plants may account for the high variation in offspring performance (Jallow \& Zalucki, 2003). Larvae mostly feed on the growing point and reproductive parts of the host plants; therefore the economic loss due to American bollworm is very high on cotton, soybeans, tobacco, chickpea and pigeon pea throughout the world (Hardwick, 1965; King et.al., 1982 and Fitt, 1989). Although chemical insecticides are widely applied to control Helicoverpa armigera, reduction in the yield of seed cotton was as high as 90 percent in some cases in Myanmar (Myat Htwe and Mya Maung, 1992). In India, 18 to 26\% yield losses due to $H$. armigera was reported by Rawat et.al. in 1970. Moreover, 41 to 
$56 \%$ yield losses were found in cotton (Kaushik et.al 1969) and 40 to 50\% yield losses in tomato (Srinivasan 1959). The management of $H$. armigera is difficult and in many crops, including cotton and pigeonpea, relies heavily on the use of insecticides (King 1994; Shanower et al. 1997). Multiple insecticide applications have led to high levels of resistance to major groups of active compounds (Fitt 1989; Armes et al. 1996). To solve this problem, one promising option could be to manage Helicoverpa armigera by releasing natural enemies.

Biological control is recognized as one of the best alternatives to the use of chemical insecticides for controlling insect pests. Pest control with natural enemies has been increasing due to environmental, economical, social and ecological problems with insecticides. Heteropteran predators are important biological control agents on leaf worms (De Clercq et. al., 2003; Lemos et. al., 2003), beet armyworms (De Clercq and Degheele 1994), Colorado potato beetles (Biever, et. al., 1992; Hough-Goldstein et. al., 1996; Tipping, et. al., 1999; Westich and HoughGoldstein, 2001), and southern green stinkbugs, respectively (De Clercq et. al., 2002), on soybean caterpillars (Marston, et. al., 1978).

Naturally occurring predators and parasitoids are regarded important in regulating the numbers of Heliothis in the field (Van den Bosch and Hagen 1966, Lingren et.al. 1968, and Van den Bosch et.al. 1969). The predatory bug Eocanthecona furcellata Wolff (Hemiptera: Pentatomidae) is found especially in cotton, chickpea and vegetable fields and has been found preying on larvae of leaf worm, spotted bollworm and American bollworm in Myanmar (Gillham, 1980; Nu Nu Yi and Win Kyi, 2000, and Khin, 2001). E. furcellata has been also reported from Southeast Asia, Japan, India, and Taiwan, and has been preying on Lepidopteran, Coleopteran and Heteropteran insects (Ahmad, 1996; Chu, 1975; Chang, 2002; Jakhmola, 1983; Prasad et. al., 1983). This predatory bug can be easily reared on larvae of Pieris rapae (Chu, 1975) and frozen preserved larvae of Spodoptera litura (Yasuda and Wakamura, 1992). The host plants of prey affect the predation rate and searching behavior of predatory Hemiptera (Yasuda, 2000 and Perdikis et.al. 2004). However, there is no publication on the predation efficacy of Eocanthecona 
furcellata with regard to $H$. armigera larvae feeding on different host plants. This may be important with regard to the surrounding vegetation for release of $E$. furcellata as a biocontrol agent to control $H$. armigera in Myanmar.

In this study, we investigated (1) the effect of host plants on the oviposition preference of $H$. armigera; (2) the effect of host plants on the performance of $H$. armigera larvae; (3) prey selection and predation of E. furcellata on American bollworm larvae reared on cotton, chickpea, tomato, wild cabbage, and artificial diet; and (4) prey reference of Eocanthecona furcellata on wrapped American Bollworm larvae reared on different host plants (cabbage, cotton and chickpea).

\section{MATERIALS AND METHODS}

\section{Culture of insects}

Eggs and adults of the pentatomid Eocanthecona furcellata (Wolff) (Hemiptera: Pentatomidae) were originally collected on November 2004 from cotton fields in Myanmar. They were released into the rearing cages $(75 \times 55 \times 75 \mathrm{~cm})$ and were kept on Diamondback moth infested wild cabbage plants because of the high egg laying capacity of Diamondback moth adults, maintaining the population density for the experiments at room temperature $\left(22 \pm 1{ }^{\circ} \mathrm{C}\right)$ under laboratory condition at the Entomology Section, Georg-August University, Goettingen, Germany. 10 male and 10 female adults of $E$. furcellata were collected randomly from the rearing cage and maintained individually in Petri-dish and starved 24 hours before the experiment.

American bollworm (Helicoverpa armigera Hübner; Lepidoptera: Noctuidae) eggs were obtained from Bayer A.G., Germany, and second instar larvae were used for the host preference experiment. 100 second instar larvae were reared on cotton plants, wild cabbage plants, chickpea plants and tomato plants for the predation efficacy test. Helicoverpa armigera larvae were also reared on a modified diet according to Shorey and Hala (1965). 
A stock culture of Diamondback moth (Plutella xylostella Linnaeus) larvae has been reared on wild cabbage plant in the rearing cage at room temperature $(22 \pm 1$ $\left.{ }^{\circ} \mathrm{C}\right)$ under laboratory condition.

\section{Culture of plants}

Cotton (Gossypium hirsutum cv. MCU 9), wild cabbage (Brassica orleracea var. viridis), Chickpea (Cicer arietinum L.) and tomato (Solanum lycopersicum variety Suso R2) were grown under controlled greenhouse conditions; plants were grown in $13 \mathrm{~cm}$ diameter pots (Sand: Clay 50: 50) for these experiments. 25 day after emergence of seedlings (25 DAE) plants were used for the oviposition experiment and four to eight weeks old plants were used for the other experiments. Seeds of G. hirsutum cv. MCU 9 were provided from Myanmar; seeds of the other plants originated from Germany.

\section{Oviposition preference of the American Bollworm}

Chickpea, cotton and tomato, and wild cabbage plants were planted at the same date and plants being 25 day old were used in this experiment. Four plant species with four replicate were set at a random position in rearing cages at room temperature $\left(22 \pm 1{ }^{\circ} \mathrm{C}\right)$ and one pair of $H$. armigera were released into these cages. The number of $H$. armigera eggs and their distribution on the plants were recorded daily. The experiment was replicated 4 times.

\section{Performance of American Bollworm larvae on different host plants}

For this experiment 100 American Bollworm larvae were reared on cabbage, chickpea, cotton and tomato in different rearing cages and on the artificial diet at room temperature $\left(22 \pm 1^{\circ} \mathrm{C}\right)$ to study the performance of $H$. armigera till the adult stage.

\section{Predation efficiency of Eocanthecona furcellata on American Bollworm reared on different host plants (cabbage, cotton, chickpea and tomato)}


American Bollworm (Helicoverpa armigera) larvae were reared on cabbage, chickpea, cotton and tomato plants in different rearing cages and on the artificial diet at room temperature $\left(22 \pm 1^{\circ} \mathrm{C}\right)$. Larvae were kept on these plants for 20 days. Thereafter ten males and ten females of adult $E$. furcellata were used in this experiment, which was replicated ten times. All E. furcellata were starved 24 hour before the experiment started. $H$. armigera larvae were fixed with tape and placed in a $15 \times 22 \times 3 \mathrm{~cm}^{3}$ plastic box and ten $E$. furcellata adults were transferred to the center of the arena. The movement of $E$. furcellata was observed and recorded at room temperature.

\section{Prey preference of Eocanthecona furcellata on wrapped American Bollworm larvae reared on different host plants}

This experiment was set up to understand in detail the effect of the prey previously feeding on different host plants on the predation by E. furcellata. American Bollworm larvae were reared on cabbage, chickpea and cotton, in different rearing cages at room temperature $\left(22 \pm 1^{\circ} \mathrm{C}\right)$. The same size of third and fourth instar larvae of $H$. armigera from different host plants were used in this experiment; ten male and female $E$. furcellata adults, were added in ten replications. All E. furcellata were starved 24 hours before the experiment. $H$. armigera larvae and their faeces were wrapped with Para film ' $M$ ' and placed randomly in a $15 \times 22 \times 3$ $\mathrm{cm}^{3}$ plastic box and ten E. furcellata adults were placed in the center of the arena. The movement of $E$. furcellata was observed and recorded at room temperature.

\section{Statistical analyses}

Analysis of variance (ANOVA) was used to determine statistical differences with regard to the development data among the host preference and predation preference tested (SPSS Inc., 2004). Means of treatments were separated by Bonferroni adjustment. 


\section{RESULT}

\section{Oviposition preference of the American Bollworm moth Helicoverpa armigera}

The number of $H$. armigera eggs placed on the 4 crop plants tested was significant different $(\mathrm{df}=3 ; \mathrm{F}=31.079 ; \mathrm{P}=0.000)$. The highest numbers of $H$. armigera eggs was recorded on chickpea plants $(46.8 \pm 11.63)$, followed by tomato, cotton and cabbage plants (Fig. 1). The majority of the $H$. armigera eggs was recorded on the upper side of the leaves of all plant species; however eggs were also found to some extend on the under side of the leaves and on the stems of all plant species.

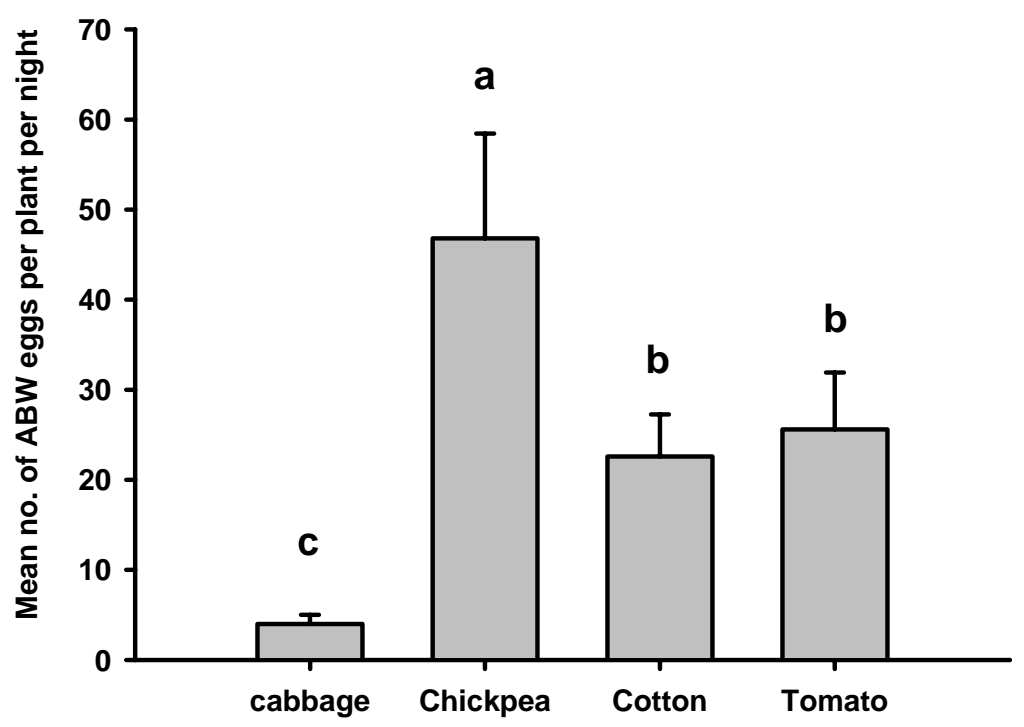

Figure 1: Oviposition preference of the American Bollworm on different host plants. Different letters indicate significant differences at $\mathrm{P}<0.01$ with Bonferroni adjustment following ANOVA.

\section{Performance of the American Bollworm larvae on different host plants}

There were significant differences in larval weights when the larvae of $H$. armigera were reared on different host plants ( $\mathrm{df}=4 ; \mathrm{F}=86.25 ; \mathrm{P}=0.000 ;$ Fig. 2 ). The average weight of the 20-day old larvae reared on wild cabbage plant, chickpea, 
cotton, tomato, and artificial diet were 182.85 ( \pm 23.4), $79.47( \pm 14.24), 147.58$ ( \pm 18.18), 18.34 ( \pm 3.74$)$, and 419.54 ( \pm 16.4$) \mathrm{mg}$, respectively.

The length of $H$. armigera larvae reared on different host plants were significantly different ( $d f=4 ; F=50.08 ; P=0.000) ;(F i g .3)$. The average length of the 20-day old larvae reared on wild cabbage, chickpea, cotton, tomato plants, and artificial diet were 24.53 ( \pm 1.25$), 17.6$ ( \pm 1.51$), 20.93( \pm 1.26), 8.8$ ( \pm 0.91$)$, and $32.87( \pm 1.26)$ $\mathrm{cm}$, respectively.

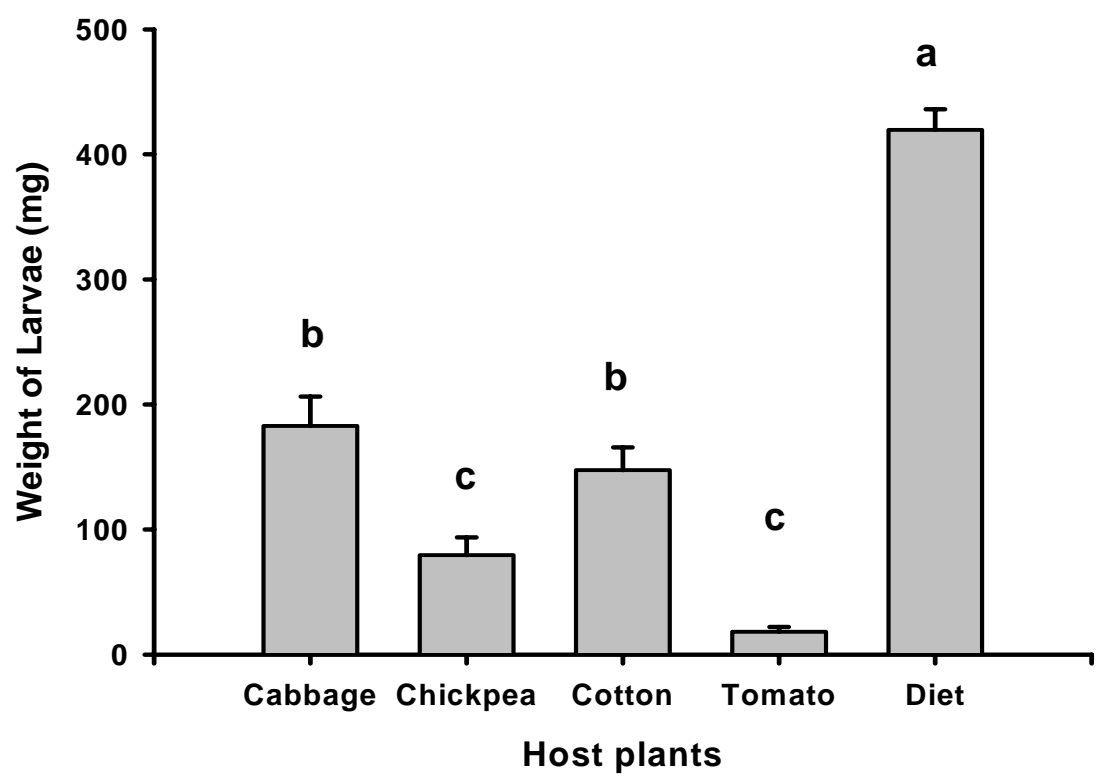

Figure 2: Weight of $H$. armigera larvae reared on different host plants. Different letters indicate significant differences at $\mathrm{P}<0.01$ with Bonferroni adjustment following ANOVA. 


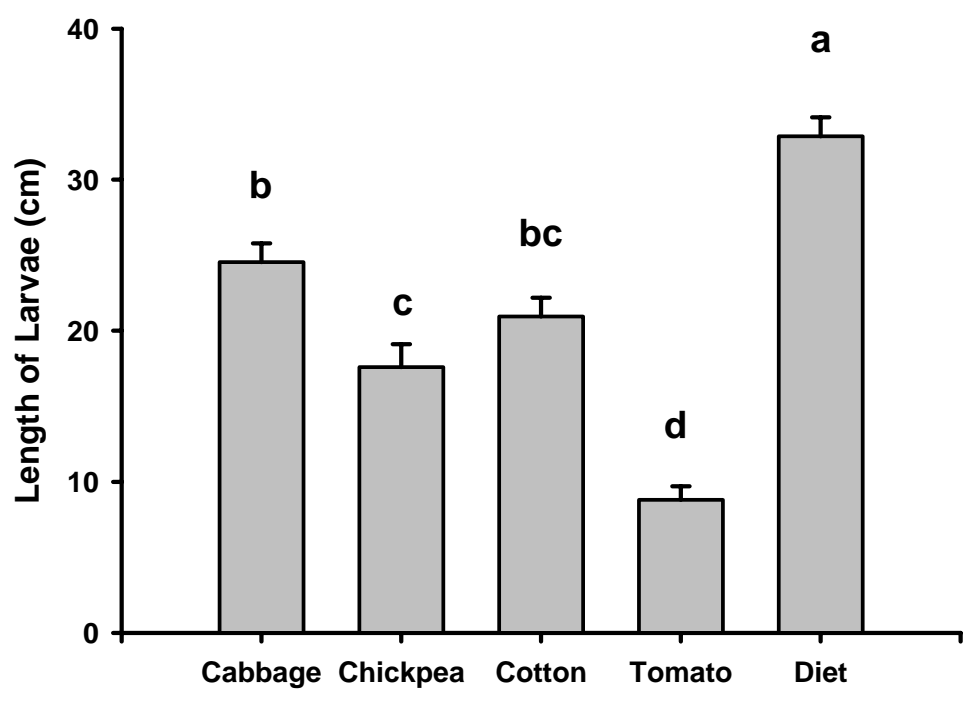

Host Plants

Figure 3: Length of $H$. armigera larvae reared on different host plants. Different letters indicate significant differences at $\mathrm{P}<0.01$ with Bonferroni adjustment following ANOVA.

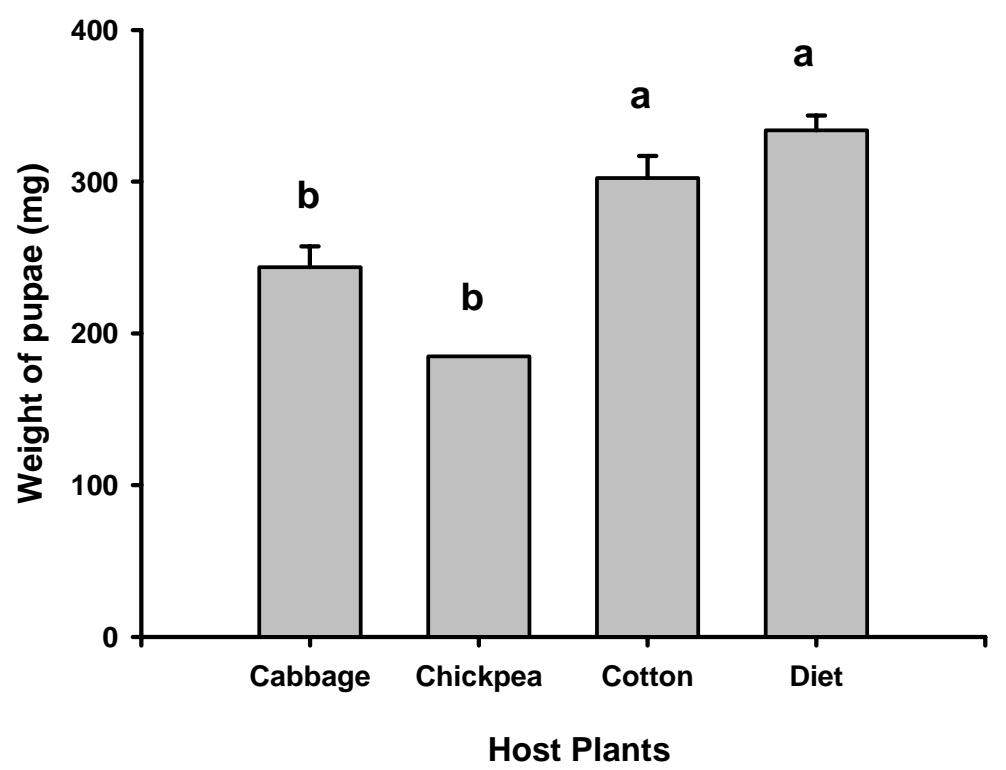

Figure 4: Weight of $H$. armigera larvae reared on different host plants. Different letters indicate significant differences at $\mathrm{P}<0.01$ with Bonferroni adjustment following ANOVA. 
The weight of $H$. armigera pupae was analysed at day 27 . Host plants significantly influenced the weight ( $\mathrm{df}=4 ; \mathrm{F}=21.55 ; \mathrm{P}=0.000 ;$ Fig.4). Weight of pupae was varying depend on the host plants; no pupae was found in tomatoes. The average weight of the pupae reared on wild cabbage plant, chickpea, cotton, and artificial diet were 243.59 ( \pm 13.77$), 184.9$ ( \pm 1.00$), 302.38$ ( \pm 14.54$)$, and $333.88( \pm 9.76)$ mg, respectively.

\section{Predation efficiency of Eocanthecona furcellata on American Bollworm Helicoverpa armigera reared on different host plants (Cabbage, Cotton, Chickpea and Tomato)}

E. furcellata produced their proboscis after placed into the center of the plastic box and approached towards the prey while touching the bottom with the tip of their antennae. Most of E. furcellata (20-60 \%) directly approached towards cotton plants preying on $H$. armigera larvae. After testing the prey with the tip of their antennae, E. furcellata tightened their antennae $\left(180^{\circ} \mathrm{C}\right)$ and used the rostrum to suck hemolymph from the prey, leaving no body fluids behind. E. furcellata shared their prey with other $E$. furcellata and once seven $E$. furcellata were preying on one $H$. armigera larvae at the same time. Although they were also preying on the faeces of $H$. armigera larvae, only one $E$. furcellata selected the $H$. armigera larvae reared on artificial diet. The majority of the $E$. furcellata preffered to suck under side of the bollworm larvae. The predation rates were $19.83( \pm 2.88), 18.33( \pm$ 2.97), 39.17 ( \pm 3.58$), 14.17( \pm 2.88)$, and $3.33( \pm 1.42) \%$ on the $H$. armigera larvae reared on wild cabbage plant, chickpea plant, cotton plant, tomato plant and artificial diet, respectively ( $\mathrm{df}=5 ; \mathrm{F}=16.97 ; \mathrm{P}=0.000) ;(\mathrm{Fig} .5) .9 .17 \%$ of $E$. furcellata did not find the prey or selected no prey in the experiments, which was recorded as no choice. 


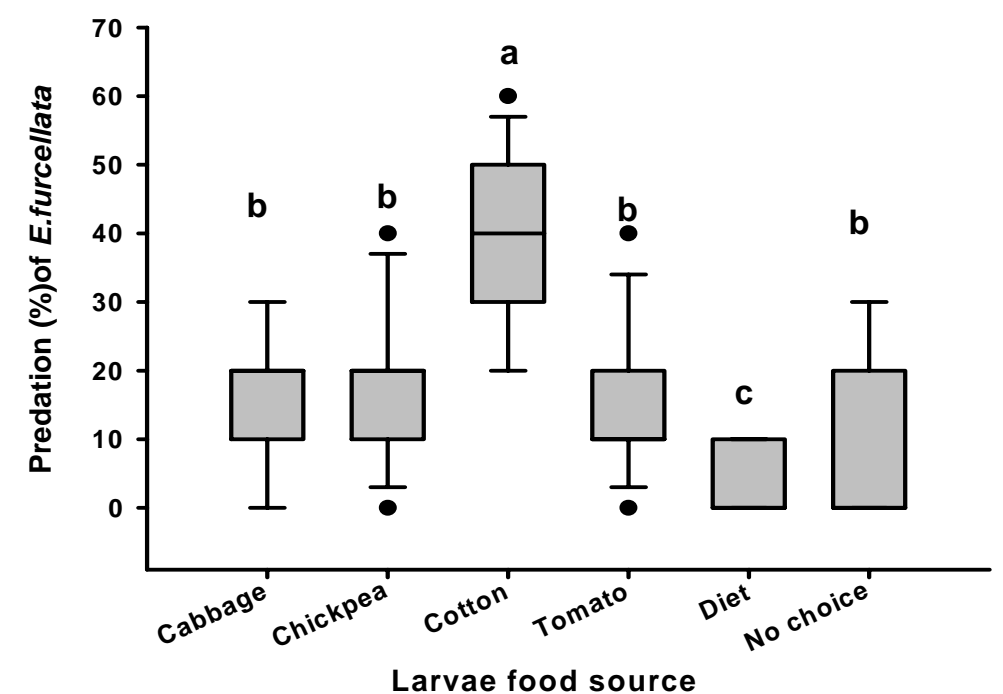

Figure 5: Predation \% of $E$. furcellata (EO) on $H$. armigera larvae reared on different host plants. Different letters indicate significant differences at $P<0.01$ with Bonferroni adjustment following ANOVA.

\section{Prey preference of Eocanthecona furcellata on wrapped American Bollworm Helicoverpa armigera (ABW) reared on different host plants (Cabbage, Cotton and Chickpea)}

When $H$. armigera larvae and their faeces were wrapped with Para film ' $M$ ', predation efficacy was significantly reduced on the larvae reared on cotton plant and cabbage plant ( $\mathrm{df}=6 ; \mathrm{F}=11.75 ; \mathrm{P}=0.000) ;(\mathrm{Fig} .6)$. The predation rates were 14.44 ( \pm 3.77$), 22.22( \pm 4.94)$, and $24.58( \pm 5.80) \%$ on the $H$. armigera larvae reared on wild cabbage plant, chickpea plant and cotton plant, respectively. 38.89 $( \pm 8.07) \%$ of $E$. furcellata were not searching for prey in the experiments and none of $E$. furcellata fed on wrapped faeces of larvae reared on wild cabbage, chickpea and cotton plants. 


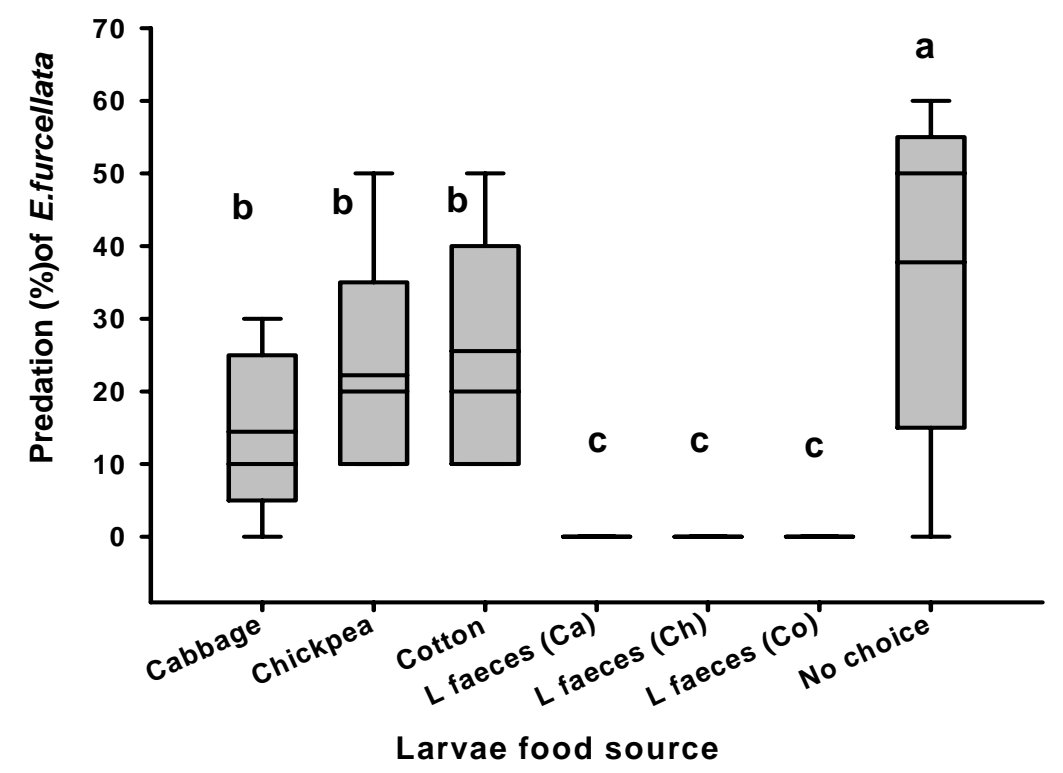

Figure 6: Predation of $E$. furcellata on the wrapped $H$. armigera larvae from different host plants. Different letters indicate significant differences at $P<0.01$ with Bonferroni adjustment after ANOVA.

\section{DISCUSSION}

Host plant species significantly influenced the oviposition of females of $H$. armigera (Fig.1). $44.23 \%$ of the females preferred to lay their eggs on chickpea plants. This host selection behavior of adult females of $H$. armigera is consistent to results reported previously by several authors (Parsons, 1940; Roome, 1975; Wardhaugh et.al., 1980; and Schneider et.al., 1986). They found that the host selection is strongly influenced by the flowering stage of their hosts. Tomato plants and cotton plants have long trichomes and even so $24.2 \%$ and $21.39 \%$ of the eggs were laid on these plants while only $2.84 \%$ wer found on cabbage plants. These results are consistent with Shanower and Romeis (1999), reporting that reproductive structures, trichome exudates and enemy-free space contributed most to the oviposition preferences.

Host plants also affected the performance of $H$. armigera larvae. The weights of the 20-day old larvae ranged from $18.34( \pm 3.74) \mathrm{mg}$ on tomato plants to 419.54 ( \pm 
16.4) mg on artificial diet. Similar result were found by Lui (2004) with body weight of young last instar $H$. armigera larvae ranging from $176.7 \mathrm{mg}$ on cotton to 132.5 mg on cherry tomatoes. Sharmad et al. (2005) also found that larvae of $H$. armigera weighed $<50 \mathrm{mg}$ when reared on Cicer pinnatifidum because the wild relatives of chickpea showing high levels of antibiosis to $H$. armigera. Cotter and Edwards (2006) discuss that plants use a numbers of resistance mechanisms affecting insect feeding, including physical factors such as leaf toughness or trichome density, or chemical factors such as toxic allelochemicals and proteinase inhibitors. Moreover, Tan et. al. (2001) and Subramanian (2006) proved the effect of host plant influence on the genetic variability of $H$. armigera populations.

Adult female of $H$. armigera preferred to lay their eggs on chickpea plants but the performance of the larvae was not better as compared to the larvae developing on cotton and cabbage plants. Several authors already discussed that females do not always oviposit on plant species on which larval performance is best (Thompson, 1988; Courtney \& Kibota, 1990; Jallow et.al., 1999; Jallow et.al., 2001; and Jallow et.al., 2003).

The predation efficacy of $E$. furcellata was tested with American Bollworm from four different host plants (cabbage, cotton, chickpea and tomato plants). The majority of E. furcellata (30-60 \%) directly approached towards cotton plants sucking on $H$. armigera larvae. Most probably, E. furcellata responsed to $(E)$ - phytol, which is produced by larvae when feeding on the chlorophyll in their food plants. E. furcellata prefers to feed on larvae fed with a chlorophyll-rich diet than with a chlorophyll-poor diet (Yasuda, 1997, 1998a, 1998b), My results correspond to these findings that larvae reared on an artificial diet, basically made from bean flour, were inadequately attractive to E. furcellata. Henaut (2000) found that adults of the predatory bug Orius majusculus (Reuter), having no experience of aphid predation as nymphs, did not prey on pea aphids in the experimental arena. Therefore, nutrient content of prey and the standard diet used for rearing $E$. furcellata may affect the efficiency of the predator as a biological control agent. 
When $H$. armigera larvae and their faeces were wrapped with Para film ' $M$ ', selection of prey was significantly reduced up to $20-40 \%$ and the numbers of bugs not feeding or not searching for prey increased. They did not select larvae faeces from different host plant and predation on the larvae fed on cotton plants was reduced by half as compared with the first experiment. Yasuda (1998b) mentioned that about $90 \%$ of the $(E)$ - phytol can be detected in the faeces of $S$. litura. $E$. furcellata fed the faeces of $H$. armigera in the first experiment but after covering with Para film ' $M$ ', none of $E$. furcellata adults was interested in faeces any more. Yasuda (1997 and 2000) proved that E. furcellata located their prey by chemical cues emanating from their prey. Para film ' $\mathrm{M}$ ' seem to prevent the visual and olfactory cues from prey larvae; and their faeces; however, we may speculate the this predatory bug may detect the prey by vibrations caused by feeding. Vibrations produced by prey as when chewing on leaves is be an important cue used by the predatory stinkbug Podisus maculiventris (Say) to locate the prey (Pfannenstiel, 1995).

\section{REFERENCE}

Ahmad M., A. P. Singh, S. Sharma, R. K. Mishra and M. J. Ahmad (1996) Potential estimation of the predatory bug Canthecona furcellata Wolff (Hemiptera: Pentatomidae) against popular defoliator Clostera cupreata (Lepidoptera: Notodontidae). Annals of Forestry 4: 133-138

Armes, N.J., D.R. Jadhav \& K.R. Desouza (1996) A survey of insecticides resistance in Helicoverpa armigera in the Indian subcontinent. Bull. Entomol. Res. 86: 499-514.

Biever, K. D. and R. L. Chauvin (1992) Suppression of the Colorado potato beetle (Coleoptera: Chrysomelidae) with augmentative releases of predaceous stinkbugs (Hemiptera: Pentatomidae). J. Econ. Entomol. 85: 720-726. 
Cotter, S.C. and O.R. Edwards (2006) Quantitative genetics of preference and performance on chickpeas in the noctuid moth, Helicoverpa armigera. Heredity 96: 396-402

Courtney S. P. \& T.T. Kibota (1990) Mother doesn't know best: selection of host by ovipositing insect. In: Insect-Plants Interactions (ed. E.A. Bernays), pp. 161188. CRC press, Boca Raton, USA.

De Clercq, P. \& D. Degheele (1994) Laboratory measurements of predation by Podisus maculiventris and $P$. sagitta (Hemiptera: Pentatomidae) on beet armyworm (Lepidoptera: Noctuidae) J. Econ. Entomol. 87: 76-83

De Clercq, P., K. Wyckhuys, H.N. De Oliveira and J. Klapwijk (2002) Predation by Podisus maculiventris on different life stages of Nezara viridula. Florida Entomologist 85(1): 197-202

De Clercq, P., I. Peeters, G. Vergauwe and O. Thas (2003) Interaction between Podisus maculiventris and Harmonia axyridis, two predators used in augmentative biological control in greenhouse crops. BioControl 48: 39-550

Fitt, G.P. (1989) The ecology of Heliothis species in relation to agroecosystems. Ann. Rev. Entomol. 7: 685-688.

Fitt, G.P. (1991) Host selection in Heliothinae. In:Reprodctive behaviour of insects: Individuals and populations (eds WJ Bailey and J Ridsdill-Smith). pp 127201. Chapman and Hall, Landon, UK.

Fitt, G.P. and G.S. Boyan (1991) Method for studying behavior. In: Helicoverpa research methods and prospects (ed. M.P. Zalucki). pp 122-150. SpringerVerlag, New York, USA.

Gillham, F.E.M. (1980) Introduction to cotton insect pest control in Burma. Seed development project report no. 22. Ministry of Agriculture and Forests, Rangoon, Burma. 77pp. 
Hardwick,D.F. (1965) The corn earworm complex.Memoris of the Entomological Society of Canada 40:247 pp.

Henaut, Y., C. Alauzet, A. Ferran, T. Citation Williams (2000) Effect of nymphal diet on adult predation behavior in Orius majusculus (Heteroptera: Anthocoridae). J-Econ-Entomol. Apr; 93(2): 252-5

Hough-Goldstein, J. and D. McPherson (1996) Comparison of Perillus bioculatus and Podisus maculiventris (Hemiptera: Pentatomidae) as potential control agents of the Colorado potato beetle (Coleoptera: Chrysomelidae). J. Econ. Entomol. 89: 1116-1123.

Jallow, M.F.A., M.P. Zalucki and G.P. Fitt (1999) Role of chemical cues from cotton in mediating host selection and oviposition behavior in Helicoverpa armigera (Hübner) (Lepidoptera: Noctuidae). Australian J. of Entomol. 38:359-366

Jallow, M.F.A., M. Matsumura and Y. Suzuki (2001) Ovipostion preference and reproductive performance of Japanese Helicoverpa armigera (Hübner) (Lepidoptera: Noctuidae). Appl. Entomol.Zool. 36 (4): 419-426

Jallow, M.F.A. and M.P. Zalucki (2003) Relation between ovipostion preference and offspring performance in Australian Helicoverpa armigera (Hübner) (Lepidoptera: Noctuidae). Australian J. of Entomol. 42: 343-348

Kaushik. U.K., V.S. Rathore and N.K. Sood (1969) Incidence of bollworms and losses caused to cotton in Madhya Pradesh. Indian J. Entomol. 31(2): 175177.

Khin Thein Nyunt (2001) Impact of planting dates on the population of cotton pests and natural enemies in Myanmar. M.Sc.agr. thesis at Georg-AugustUniversity, Goettingen, Germany. 99 pp.

King E.G., J.E. Powell, and J.W Smith (1982) Prospects for utilization of parasites and predators for management of Heliothis spp. In proceedings of the 
international workshop on Heliothis management (W. Reed and Kumble eds.). ICRISAT; Patancheru, A. P., India. 103-122 pp

King A.B.S. (1994) Heliothis/Helicoverpa (Lepidoptera: Noctuidae). In Insect Pests of Cotton, Mathews G.A. and Turnstall J.P. (eds.). CAB International. Wallingford, U.K. 39-106 pp.

Lemos, W. P., F. S. Ramalho, J. E. Serrão, and J. C. Zanuncio (2003) Effects of diet on development of Podisus nigrispinus (Dallas) (Het., Pentatomidae), a predator of the cotton leafworm. J. Appl. Ent., 127, 389-395.

Lingren, P.D., R.L. Ridgway, and S.L. Jones (1968) Consumption by several common arthropod predators of eggs and larvae of two Heliothis species that attack cotton. Ann.Entomol. Soci. . America 61: 613-618

Liu, Z., Dianmo Li, Peiyu Gong, and Kunjun Wu (2004) Life Table Studies of the Cotton Bollworm, Helicoverpa armigera (Hübner) (Lepidoptera: Noctuidae), on Different Host Plants. Env. Entomol. 33(6): 1570-1576

Marston, N. L., G. T.Schmidt, K. D. Biever, and W. A. Dickerson, (1978) Reaction of five species of soybean caterpillars to attack by the predator, Podisus maculiventris. Env. Entomol. 7: 53-56.

Morris, H. and D. F. Waterhouse (2001) The distribution and important of arthropod pest and weeds of agriculture in Myanmar. ACIAR Monograph No. 67,73 pp.

Myat Htwe and Mya Maung (1992) National IPM programme of the Union of Myanmar. In Ooi, P.A.C.et. al. (ed) (1992) IPM in the Asia-Pacific Region. Proc. of the Conf. on IPM in the Asia-Pacific Region, 23-27, September 1999, Kuala Lumpur, Malaysia

Nu Nu Yi and Win Kyi (2000) Biological control of cotton bollworm and chickpea pod borer, Helicoverpa armigera y using predator Eocanthecona furcellata 
and parasitoid Campoletis chlorideae. In proceeding of the annual research conference, April 3-5, 2000, Yangon, Myanmar. 58-74 pp.

Persons, F.S. (1940) Investigations on the bollworm, Heliothis armigera, Hübn, Part III. Relationships between oviposition and the flowering curves of foodplants. Bull Entomol. Res. 31:147-177

Pearson, E.O. (1958) The insect pest of cotton in tropical Africa. Comonweath Inst. Entomol. London.335 pp.

Perdikis, D.CH., D.P. Lykouressis, and L.P. Economou (2004) Influence of lightdark phase, host plant, temperature, and their interactions on an insect predator. Env. Entomol. 33(5): 1137-1144

Pfannenstiel, R. S., R. E. Hunt and K. V. Yeargan (1995) Orientation of a Hemipteran predator to vibrations produced by feeding caterpillars. Journal of Insect Behavior 8(1): 1-9

Rawat, R.R., S.S. Jakhmola and U.R. Sahu (1970) Assessment of losses of hybrid sorghum CSH1 to earhead caterpillars, and comparison of insecticidal controls. PANS 16(2):367-369

Reed, W. and C.S. Pawar (1982) Heliothis: A global problem. In proceedings of the international workshop on Heliothis management (W. Reed and Kumble eds.). ICRISAT; Patancheru, A. P., India. 9-14 pp.

Roome, R.E. (1975) Activity of adut Heliothis armigera (Hübner) (Lepidoptera: Noctuidae) with reference to the flowering of sorghum and maize in Bostswana. Bull. Entomol. Res. 65: 523-530

Schneider, J.C., J.H. Benedict, F. Gould, W.R. Meredith, M.F. Schuster, G.R.Zummo (1986) Interaction of Heliothis with its host plants. In : S.J. Johnson, E.G. King, J.R. Bradley (Eds.), Theory and Tactics of Heliothis population management: I - Cultural and Biological control. Southern 
Cooperative Series Bulletin 316, Stillwater: Oklahoma State University, 2-21 pp.

Shanower. T.G., T.G. Kelley \& S.E. Cowgill (1997) Development of effective and aenvironmentally sound strategies to control Helicoverpa armigera in Pigeonpea and Chickpea production systems. In: R.K. Saini (ed), Tropical Entomology 1994. Nairobi, Kenya. ICIPE Science Press, 255-276 pp.

Shanower, T.G. and J. Romeis (1999) Insect pests of pigeonpea and their management. Ann. Rev. Entomol. 44: 77-96

Sharmad, H., G. Pampapathy, S. Lanka, and Ridsdill-Smith, T. (2005) Antibiosis mechanism of resistance to pod borer, Helicoverpa armigera in wild relatives of chickpea Euphytica 142(1-2): 107-117(11)

Shorey, H.H. \& R.L. Hala (1965) Mass rearing of some noctuid species on a simple artificial medium. J. Econ. Entomol. 58: 522-544.

SPSS Inc., (2004) Systat 11 for Windows; SPSS Inc., Chicago, USA.

Srinivasan, P.M. (1959) Control of fruit borer H.armigera (Hb.) on tomato. Indian Journal of Hoticulture 16: 187-188.

Stamp, N. E., T. Erskine, and C. J. Paradise (1991) Effects of rutin-fed caterpillars on an invertebrate predator. Oecologia, 88, 289-295

Tan, S., X. Chen, A. Zhang and D. Li (2001) Isolation and characterization of DNA microsatellite from cotton bollworm (Helicoverpa armigera, Hübner)

Tipping, P. W., Carol A. Holko, Aref A. Abdul-Baki, and Jeffrey R. Aldrich (1999) Evaluating Edovum puttleri Grissell and Podisus maculiventris (Say) for augmentive biological control of Colorado potato beetles in tomatoes. Biological Control, 16 (1), 35-42 
Thompson J. N.(1988) Evolutionary ecology of the relationship between oviposition preference and performance of offspring in phytophagous insects. Entomol. Exp. Appl. 47:3-14

Van den Bosch, R. and K.S. Hagen (1966) Predaceous and parasitic arthropods in California cotton fields. California Agricultural Experiment Station Bulletin 820. University of California, Berkeley, Calif, USA. 32 pp.

Van den Bosch, R., T.F. Leigh, D. Gonzalez and R.E. Stinner (1969) Cage studies on predators of the bollworm in cotton. J. Econ. Entomol. 62: 1486-1489

Wardhaugh, K.G., P. M. Room, L.R. Greenup (1980) The incidence of Heliothis armigera (Hübner) and $H$. punctigera Wallengren (Lepidoptera: Noctuidae) on cotton and other host plants in the Namoi Valley of New South Wales. Bull. Entomol. Res. 70: 113-131

Westich, R. and Judith Hough-Goldstein (2001) Temperature and host plant effects on predatory stink bugs for augmentative biological control. Biological Control, 21 (2): 160-167

Yasuda, T. and S. Wakamura (1992) Rearing of the predatory stink bug Eocanthecona furcellata (Wolff) (Hemiptera: Pentatomidae), on frozen larvae of Spodoptera litura (Fabricius) (Lepidoptera: Noctuidae). Appl. Entomol. Zool., 27:303-305

Yasuda, T. (1997) Chemical cues from the Spodoptera litura larvae elicit preylocating behavior of generalist predatory stink bug Eocanthecona furcellata. Entomol. Exp.Appl.82: 349-354

Yasuda, T. (1998a) Effects of (E)- Phytol of several lepidopteran species in preylocating behavior of generalist predatory stink bug Eocanthecona furcellata (Heteroptera: Pentatomidae). Entomol.Sci. 1:159-164 
Yasuda, T. (1998b) Role of chlorophyll content of prey diets in prey- locating behavior of generalist predatory stink bug Eocanthecona furcellata. Entomol. Exp.Appl.86: 119-124

Yasuda, T. (2000) Role of semiochemicals in prey- locating behavior of a generalist predatory stink bug Eocanthecona furcellata (Heteroptera: Pentatomidae). Jpn. Agri. Res. Q. 34:15-20

Zalucki, M. P., G. Daglish, S. Firempong, and P. Twine (1986) The biology and ecology of Heliothis armigera (Hübner) and $H$. punctigera Wallengern (Lepidoptera: Noctuidae) in Australia: What do we know? Aust. J. Zool. 34: 779- 814 


\section{Chapter 2}

\section{Prey consumption and fitness of Eocanthecona furcellata Wolff (Hemiptera: Pentatomidae) on Diamondback Moth larvae at different temperature regimes and prey density}

\section{ABSTRACT}

The predatory bug (Eocanthecona furcellata (EO), native to Southeast Asia offers potential to be used as a biological control agent against lepidopteran pests. However, in order to establish mass rearing methods, the life history of $E$. furcellata has to be evaluated in detail. Temperature is the most important environmental factor affecting development of insects and prey consumption of the predator.

We investigated the effect of three temperature regimes and prey densitytemperatures on the development, prey consumption and predation rate of the bug using Diamondback Moth larvae (DBM) Plutella xylostella L. (Lepidoptera: Plutellidae) under laboratory conditions. We used $2^{\text {nd }}$ instars of $E$. furcellata nymphs at three constants temperatures and eight different diamondback moth larval densities.

The maximum prey consumption per day and E. furcellata larvae was rather high, exeeding $9.65( \pm 0.29)$ larvae at $30^{\circ} \mathrm{C}$ in the 5 th instar of $E$. furcellata. During the whole lifecycle $\left(2^{\text {nd }}\right.$ instar to adult), E. furcellata consumed a minimum of 13.00 $\left( \pm 1.08\right.$ diamondback moth larvae at $35^{\circ} \mathrm{C}$ to a maximum of $102.25 \pm 2.84$ diamondback moth larvae at $25^{\circ} \mathrm{C}$. The shortest nymphal developmental time (egg to adult) was found at $35^{\circ} \mathrm{C}$ daily offering 10 Diamondback moth larvae as a prey with 14.75 ( \pm 0.25$)$ days, whereas the longest developmental time was 35.25 ( \pm 0.25 ) days at $25^{\circ} \mathrm{C}$ fed with only 1 diamondback moth larva.

For the extreme temperature regime experiment, E. furcellata was reared at constant temperatures $\left(15,20,37\right.$, and $40^{\circ} \mathrm{C}$, respectively) in climatic cabinets at $75 \% \mathrm{RH}$ and 12:12 (L: D) photoperiod. The longest developmental time of EO from egg to adult was recorded at $20^{\circ} \mathrm{C} 116.0( \pm 1.14)$ days, while $E$. furcellata did not develop at $15^{\circ} \mathrm{C}$ and $40^{\circ} \mathrm{C}$. The maximum prey consumption per day per adult $E$. 
furcellata was very high and was on average $23.1( \pm 0.6)$ Diamondback moth larvae at $37^{\circ} \mathrm{C}$. Individuals consumed up to $388.9( \pm 8.2)$ larvae at $37^{\circ} \mathrm{C}$ during the whole developmental time. E. furcellata females deposited on average $14.8( \pm 3.2)$ eggs per batch at $37^{\circ} \mathrm{C}$, but these eggs failed to begin embryonic development. Therefore no viable offspring were recorded at the four tested extreme temperatures. Our data suggest that $E$. furcellata is adapted to climatic conditions prevailing in the tropical regions and may be used for biological control purposed only in areas with mean temperatures above $25^{\circ} \mathrm{C}$.

Keywords: Biological control, Eocanthecona furcellata, Diamondback moth, Myanmar, temperature, prey density

\section{INTRODUCTION}

The Diamondback moth (Plutella xylostella Linnaeus) (Lepidoptera: Plutellidae) (DBM) is a major pest of cabbage and cauliflower and severe infestations are regularly found in the Bago and Mandalay Division, the main vegetable growing area in Myanmar (Morris and Waterhouse, 2001). The diamondback moth is well known as a worldwide pest of cruciferous crops, such as broccoli and cabbage, and is often found on cruciferous weeds (Harcourt, 1957; Talekar \& Shelton, 1993; and Voice \& Chapman, 2000). Several Diamondback moth populations in the major production regions are known to be resistant to several insecticidal compounds, including resistance to Bacillus thuringiensis and insect growth regulators in Hawaii, India, Australia, New Zealand; South-East Asia, Japan, USA and Central America, respectively (Tabashnik et al., 1987; Saxena et al., 1989; Endersby \& Ridland, 1994; Bell and Fenemore, 1990; Sun,1992). In addition, insecticide applications increased the costs of production, have resuced the numbers of non-target arthropod predators, thereby reducing biodiversity, have increased the chances of consumers eating pesticide-contaminated products, and have contaminated soil and water. To avoid these consequences, biological control measures to control Diamondback moth populations are recommended. 
The pentatomid predatory bug Eocanthecona furcellata (Wolff), preying on the larvae of Spodoptera litura and Helicoverpa armigera, was regularly found in cauliflower and cotton fields in Myanmar (Gillham, 1980; Nu Nu Yi and Win Kyi, 2000, and Khin, 2001). E. furcellata has been documented as a predator in Southeast Asia, Japan, India, and Taiwan, repsectively, preying on larvae of Lepidoptera, Coleoptera and Heteroptera (Ahmad, 1996; Chu, 1975; Chang, 2002; Jakhmola, 1983; Prasad et. al., 1983). In Myanmar, E. furcellata has been reared on larvae of Spodoptera litura at room temperature $\left(27-30^{\circ} \mathrm{C}\right)$. Chu (1975) proved that $E$. furcellata can be easily reared on larvae of Pieris rapae at $25^{\circ} \mathrm{C}$ in Taiwan and Yasuda and Wakamura (1992) investigated that E. furcellata can be maintain on frozen-preserved larvae of Spodoptera litura at $26^{\circ} \mathrm{C}$ in Japan. Ho et.al. (2003) used Alphitobius sp. (Coleoptera: Tenebrionidae) and Chrysomya megacephala (Fabricius) (Diptera: Callipaoridae) for rearing E. furcellata at $\left(23 \pm 3^{\circ} \mathrm{C}\right)$ in China. Based on previous host range tests, E. furcellata accepted Diamondback moth as prey and diamondback moth larvae may thus be used for rearing E. furcellata under the laboratory conditions in Germany.

The ability of a natural enemy to adapt to different environmental conditions is an essential prerequisite for its successful utilization in a biological control program. Among other environmental conditions, temperature is considered to be a key factor affecting the biology and ecology of both harmful and beneficial insects (Hassell, 1985). Constant temperatures affected the development and survival of the predatory bug Podisus maculiventris (Say) (De Clercq and Degheele, 1992; Mohaghegh et. al., 2001 and Legaspi, 2004). Temperature also influenced the metabolism, reproduction and longevity of the predatory bug Podius nigrispinus (Dallas) (De Clercq and Degheele, 1990, 1992; Torres et.al., 1998 and Medeiros et.al., 2003a,b). Therefore, the optimal temperature for $E$. furcellata rearing and low and high temperature thresholds for releasing the predator in the field needs to be evaluated.

Prey density can also influence the biology and efficacy of predators (Solomon 1949). It is important to understand the influence of temperature and prey density 
with regard to E. furcellata when considering this species for a biological control program to control the Diamondback moth. Data on the effect of temperature and prey density on $E$. furcellata fed with Diamondback moths are not available.

Taking this into consideration, prey consumption and fitness of the pentatomid predator Eocanthecona furcellata was studied at three constant temperatures $\left(25^{\circ} \mathrm{C}, 30^{\circ} \mathrm{C}\right.$ and $\left.35^{\circ} \mathrm{C}\right)$ using eight different prey densities and at four extreme temperatures.

\section{MATERIAL AND METHODS}

\section{Laboratory rearing}

Eocanthecona furcellata (Wolff) (Hemiptera: Pentatomidae) (EO) eggs and adults were originally collected in November 2004 from cotton fields in Myanmar. They were released in rearing cages $(75 \times 55 \times 75 \mathrm{~cm})$ and fed with Diamondback moth (DBM) at room temperature $\left(22 \pm 1{ }^{\circ} \mathrm{C}\right)$ under laboratory conditions at the Entomology Section, Georg-August University, Goettingen, Germany.

A stock culture of the Diamondback moth larvae was reared on cabbage plants in a rearing cage $(75 \times 55 \times 75 \mathrm{~cm})$ at room temperature $\left(22 \pm 1^{\circ} \mathrm{C}\right)$ under laboratory condition and last instar larvae were used as a prey for the experiments.

\section{Effect of different temperature regimes and prey density on the development time, prey consumption and predation rate}

The development time of eggs and development time, prey consumption, and predation rate of nymphs were observed in climatic exposure test cabinets with constant temperatures at $25^{\circ} \mathrm{C}, 30^{\circ} \mathrm{C}$, and $35^{\circ} \mathrm{C}$, respectively. The photoperiod in all experiments was 12:12 (L: D) $h$ and the relative humidity $(\mathrm{RH})$ was $75 \%$. Newly laid E. furcellata eggs were collected from the laboratory colony and placed in 9 $\mathrm{cm} \varnothing$ plastic Petri dishes and transferred to the climatic exposure test cabinets and incubation periods and hatching nymphs were recorded. 
For the nymphal development studies, newly hatched $2^{\text {nd }}$ instars of $E$. furcellata nymphs were collected from the laboratory colony and used for each treatment; three temperatures $\left(25^{\circ} \mathrm{C}, 30^{\circ} \mathrm{C}\right.$, and $\left.35^{\circ} \mathrm{C}\right)$, eight different densities of prey $(1,2$, $3,4,5,6,8$, and 10 diamondback moth larvae, repsectively) in four replications were used. For the tests Diamondback moth larvae were placed in $9 \mathrm{~cm} \varnothing$ plastic Petri dishes and one E. furcellata nymph was placed in the center of each arena. A moistened cotton wool was also placed in all experimental Petri dishes to keep the temperature and humidity fixed. These Petri dishes were then transferred to the climatic exposure test cabinets with constant temperatures at $25^{\circ} \mathrm{C}, 30^{\circ} \mathrm{C}$, and $35^{\circ} \mathrm{C}$, respectively. Larvae consumed per day, larvae still alive and molting date were recorded for this experiment till adult stage of $E$. furcellata. Killed Diamondback moth larvae were replaced daily throughout the experiments to maintain the tested prey densities constant.

\section{Effect of high constant temperatures on the development, mortality and prey consumption of Eocanthecona furcellata}

These experiments aimed at understanding the effect of four extreme temperatures $\left(15^{\circ} \mathrm{C}, 20^{\circ} \mathrm{C} 37^{\circ} \mathrm{C}\right.$, and $40^{\circ} \mathrm{C}$, respectively) on prey consumption, survivorship and longevity of the predatory bug E. furcellata. $2^{\text {nd }}$ instars of $E$. furcellata nymphs were used for each treatment at four temperatures and ten replications. Diamondback moth larvae were used as prey for the predator in this experiment. Diamondback moth larvae were placed in $9 \mathrm{~cm} \varnothing$ plastic Petri dishes and one $E$. furcellata nymph was placed in the center of each arena. A moistened cotton wool was also placed in all experimental Petri dishes to keep the temperature and humidity constant. These Petri dishes were then transferred to growth chambers with constant temperatures at $15^{\circ} \mathrm{C}, 20^{\circ} \mathrm{C}, 37^{\circ} \mathrm{C}$, and $40^{\circ} \mathrm{C}$, respectively. All cabinets were set at $75 \%$ relative humidity $(\mathrm{RH})$ and $12: 12(\mathrm{~L}: \mathrm{D})$ photoperiod. Daily consumed larvae, larvae still alive and data on molting were recorded for these experiments until all $E$. furcellata specimens were dead. 


\section{Statistical analyses}

Analysis of variance (ANOVA) was used to determine statistical differences in the development data among the temperature and densities tested (SPSS Inc., 2004). Means of treatments were separated by Bonferroni adjustment.

\section{RESULT}

\section{Effect of different temperature regimes and prey density on the development time, prey consumption and predation rate of Eocanthecona furcellata}

Temperature significantly affected Eocanthecona furcellata egg development ( $\mathrm{df}=$ 2; $F=1.047 ; P=0.000)$, and first instar nymph development $(\mathrm{df}=2 ; \mathrm{F}=2.094 ; \mathrm{P}=$ 0.000) (Fig. 1; Appendix 1). The time required for egg development decreased with increasing temperatures up to $35^{\circ} \mathrm{C}$, and ranged from $10.84( \pm 0.07)$ days at $25^{\circ} \mathrm{C}$ to $4.81( \pm 0.07)$ days at $35^{\circ} \mathrm{C}$.

Total development, measured in days (egg to adult), decreased from 31.00 ( \pm $0.00)$ days at $25^{\circ} \mathrm{C}$ to $19.25( \pm 0.25)$ days at $30^{\circ} \mathrm{C}$ and $14.75( \pm 0.25)$ days at $35^{\circ} \mathrm{C}$, when 10 Diamondback moth larvae were offered as a prey (Fig. 2). The $5^{\text {th }}$ instar nymph of E. furcellata had the longest development time at all temperature. The development time of $E$. furcellata nymphs was also significantly different at different prey densities (Appendix 1). Nymph developmental times decreased when increasing prey densities up to 10 DBM larvae. The interaction of temperature and prey densities also affected the longevity of $E$. furcellata (Appendix 1 ). The shortest nymph development time 14.75 ( \pm 0.25 days) was found at $35^{\circ} \mathrm{C}$ when 10 Diamondback moth larvae were offer per day, whereas the longest was 35.25 ( \pm 0.25 ) days at $25^{\circ} \mathrm{C}$ fed with only 1 Diamondback moth larva.

Daily prey consumption of E. furcellata on Diamondback moth larvae gradually increased with increasing prey densities (Fig. 3). The highest numbers of daily prey consumption per $5^{\text {th }}$ instar nymphs of $E$. furcellata were found at $30^{\circ} \mathrm{C}(9.65 \pm 0.15$ larvae) when 10 Diamondback moth larvae were offered; a decreasing prey consuming rate was found at the higher temperature regime $(7.43 \pm 0.08$ larvae at 
$35^{\circ} \mathrm{C}$ ) and at the lower temperature regime $\left(8.46 \pm 0.27\right.$ larvae at $\left.25^{\circ} \mathrm{C}\right)$ (Appendix.2). Total prey consumed by $E$. furcellata nymph was minimum 18.25 ( \pm $0.25), 15.25$ ( \pm 0.48 ) and 13.00 ( \pm 1.08 ) larvae and maximum $102.3( \pm 2.84), 70.50$ $( \pm 3.18)$ and $65.25( \pm 2.43)$ larvae at $25^{\circ} \mathrm{C}, 30^{\circ} \mathrm{C}$ and $35^{\circ} \mathrm{C}$, respectively. Daily prey consumption rates were significantly different between the three temperatures tested and the eight different prey densities (Table.1).

Predation rates of $E$. furcellata on 10 diamondback moth larvae increased with nymphal instar and at $25^{\circ} \mathrm{C}$, the predation rates were $40.83( \pm 1.59), 42.5( \pm 4.38)$, $60.0( \pm 3.85)$ and $84.64( \pm 2.69) \%$ for $2^{\text {nd }}, 3^{\text {rd }}, 4^{\text {th }}$, and $5^{\text {th }}$ instars, respectively. Nymphs preyed on $58.75( \pm 4.47), 65.63$ ( \pm 4.83$), 74.41$ ( \pm 8.32), and 96.46 ( \pm 4.46) \% ; and 65,5 ( \pm 4.79$), 66.25$ ( \pm 2.39$), 67.0( \pm 2.89)$ and $74.25( \pm 0.75) \%$ for $2^{\text {nd }}, 3^{\text {rd }}, 4^{\text {th }}$, and $5^{\text {th }}$ instars at $30^{\circ} \mathrm{C}$ and $35^{\circ} \mathrm{C}$, respectively (Fig. 4 ).

The predation rates of $E$. furcellata decreased with increasing prey densities and an optimal predation rate was found at $30^{\circ} \mathrm{C}$ (Fig. 5; Appendix 3). Mean predation rates were 97.67( \pm 1.34$), 97.67( \pm 1.34), 86.79$ ( \pm 1.28$), 87.72( \pm 3.72), 84.14( \pm$ $0.71), 83.78( \pm 2.00), 64.57( \pm 1.64), 66.5( \pm 1.63)$, and $63.91( \pm 1.77) \%$ for preying on $1,2,3,4,5,6,8$, and 10 larvae of DBM at $25^{\circ} \mathrm{C}$ and $100.0( \pm 0.00)$, 91.55 ( \pm 2.49 ), 90.31 ( \pm 4.08 ), 86.82 ( \pm 1.40 ), 86.86 ( \pm 1.33 ), 88.80 ( \pm 3.51 ), 71.28 $( \pm 2.13)$, and $76.31( \pm 3.58)$ at $30^{\circ} \mathrm{C}$; and $96.13( \pm 2.25), 87.23( \pm 3.48), 97.73( \pm$ 2.27), 93.58 ( \pm 1.73 ), 96.46 ( \pm 2.05$), 64.77$ ( \pm 2.78$), 71.04( \pm 2.59)$, and 74.55 ( \pm $1.41)$ at $35^{\circ} \mathrm{C}$. Regarding the predation rates of $E$. furcellata, the effects of temperature and prey density as well as their interaction were significant (Appendix 3 and Table 1).

Statistical analyses revealed that temperature and prey density as well as their interaction significantly affected mean adult weight ( $d f=2 ; F=5.952 ; P=0.004)$; (df $=7 ; \mathrm{F}=17.15 ; \mathrm{P}=0.000$ ) (Table 1). Adult weight of $E$. furcellata increased with increasing prey densities (Fig. 6) and E. furcellata attained significantly lower weight in lowest prey treatment (1 Diamondback moth larvae) at all temperatures; 42.15 ( \pm 2.82$), 40.35$ ( \pm 4.01 ), and $32.25( \pm 2.45) \mathrm{mg}$ at $25^{\circ} \mathrm{C}, 30^{\circ} \mathrm{C}$ and $35^{\circ} \mathrm{C}$, respectively. Maximum adult weight was $77.97( \pm 3.33)$, and $82.00( \pm 7.64) \mathrm{mg}$ for 
10 Diamondback moth larvae at $30^{\circ} \mathrm{C}$ and $35^{\circ} \mathrm{C}$, and $87.85( \pm 13.03) \mathrm{mg}$ for 8 Diamondback moth larvae at $25^{\circ} \mathrm{C}$. The gender of $E$. furcellata also effected adult weight at the three tested temperatures, with the females being heavier and bigger than males.

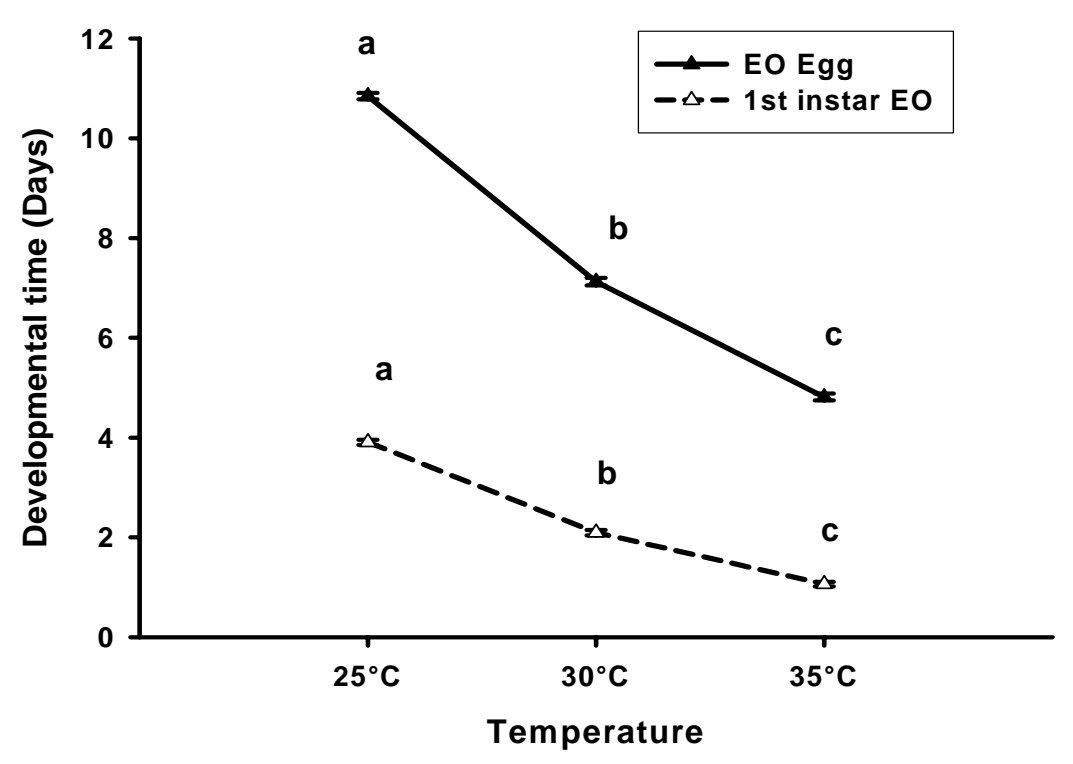

Figure 1: Developmental time [days] of E. furcellata eggs and $1^{\text {st }}$ instars at different temperatures. Different letters indicate significant differences at $P<0.01$ with Bonferroni adjustment following ANOVA. 


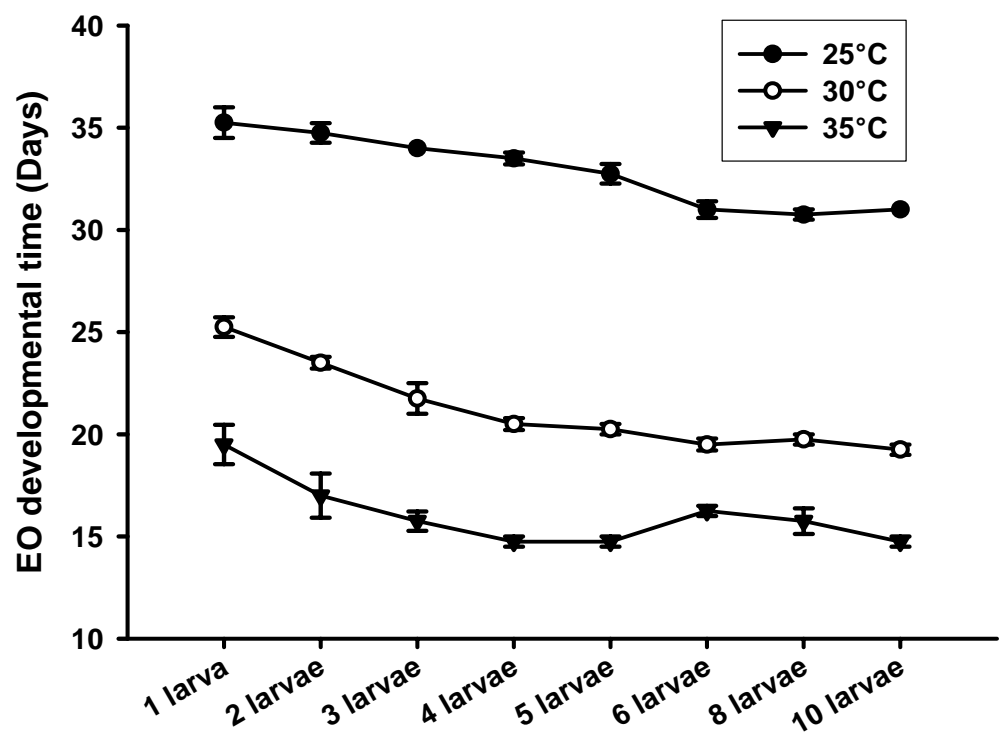

Prey density (DBM Larvae)

Figure 2: Developmental time [mean $\pm S E$ ] of $E$. furcellata (EO) at different temperatures when offered different prey densities

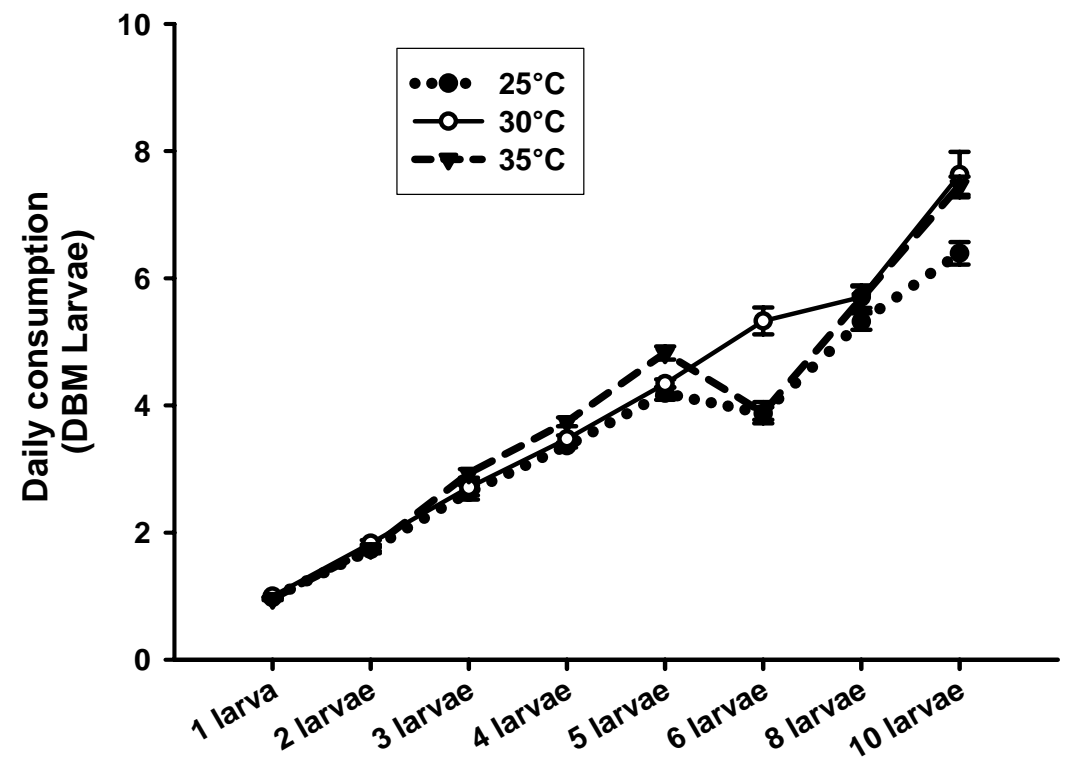

Different Prey Density

Figure 3: Daily prey consumption [mean $\pm S E$ ] of $E$. furcellata at different temperatures when offered different prey densities 


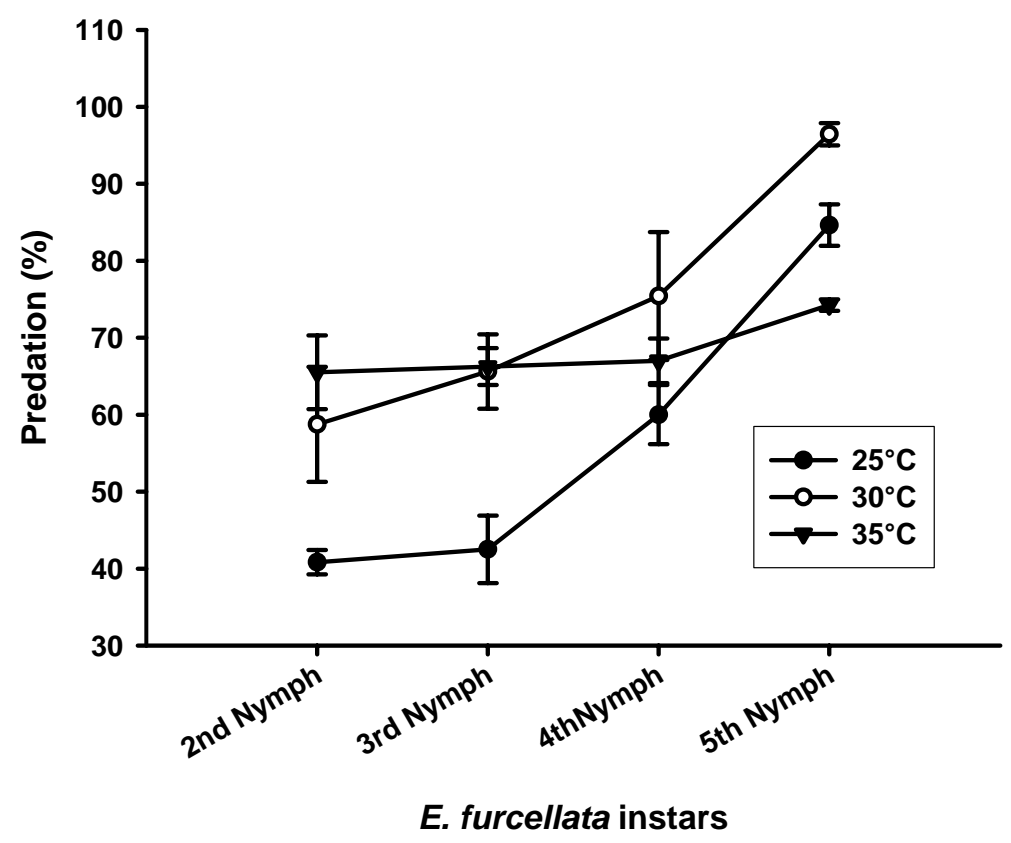

Figure 4: Predation rates [mean $\pm S E$ ] of the four instars of $E$. furcellata on 10 Diamondback moth larvae at different temperatures

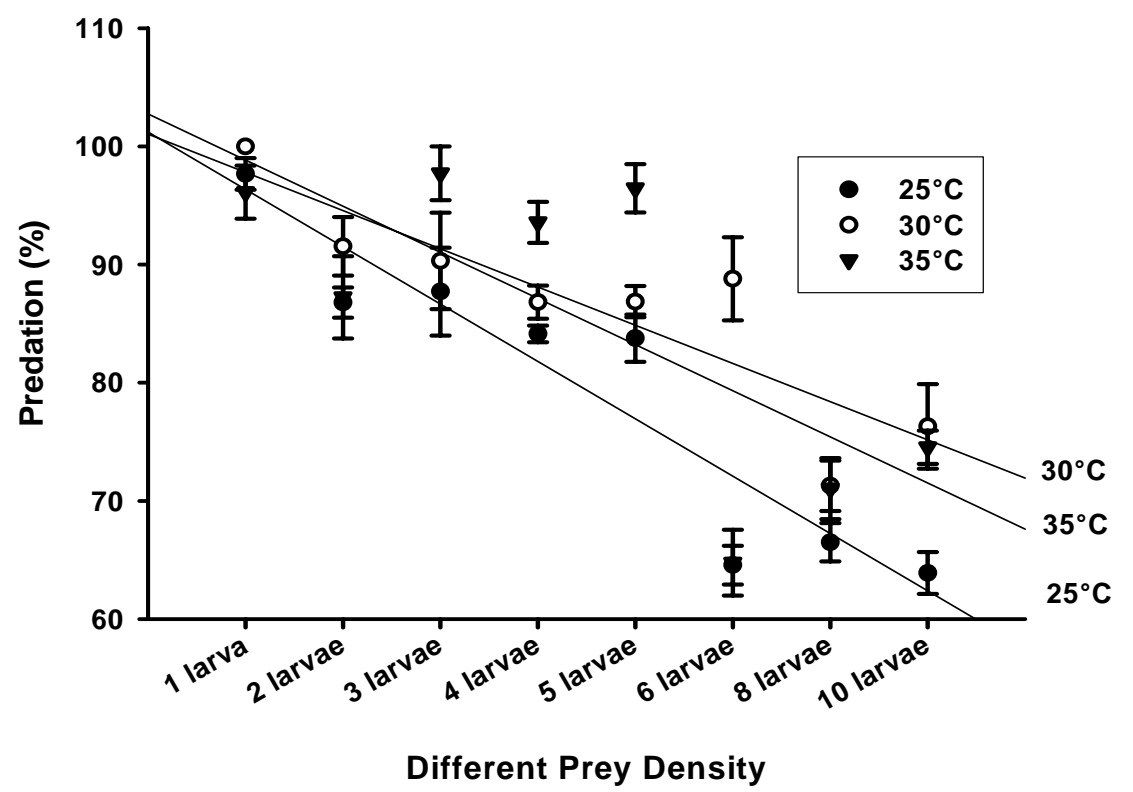

Figure 5: Mean Predation rate [mean $\pm S E$ ] of $E$. furcellata at different temperatures offered with different prey density 


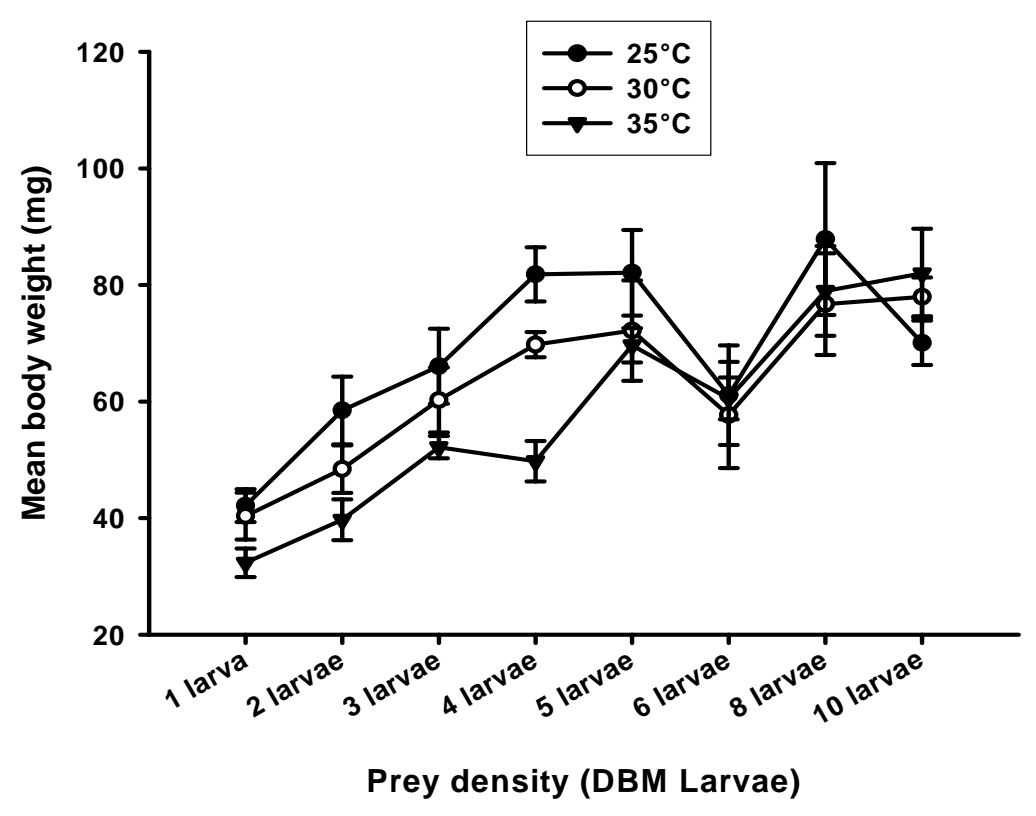

Figure 6: Adult body weight [mean $\pm S E$ ] of $E$. furcellata at different temperatures when offered different prey densities of Diamondback moth larvae 


\begin{tabular}{|c|c|c|c|c|c|}
\hline Source & $\begin{array}{l}\text { Sum-of- } \\
\text { Squares }\end{array}$ & df & $\begin{array}{l}\text { Mean- } \\
\text { Square }\end{array}$ & F-ratio & $\mathbf{P}^{*}$ \\
\hline \multicolumn{6}{|c|}{ MEAN LIFEDAYS (Egg to Adult) } \\
\hline TEMPERATURE & 4747.89 & 2 & 2373.948 & 2579.989 & 0.000 \\
\hline DENSITY & 247.823 & 7 & 35.403 & 38.476 & 0.000 \\
\hline $\begin{array}{l}\text { TEMPERATURE* } \\
\text { DENSITY }\end{array}$ & 42.771 & 14 & 3.055 & 3.320 & 0.000 \\
\hline Error & 66.250 & 72 & 0.920 & & \\
\hline \multicolumn{6}{|c|}{ MEAN DAILY CONSUMPTION } \\
\hline TEMPERATURE & 3.44 & 2 & 1.721 & 24.317 & 0.000 \\
\hline DENSITY & 340.59 & 7 & 48.656 & 687.432 & 0.000 \\
\hline $\begin{array}{l}\text { TEMPERATURE* } \\
\text { DENSITY }\end{array}$ & 7.52 & 14 & 0.537 & 7.585 & 0.000 \\
\hline Error & 5.10 & 72 & 0.071 & & \\
\hline \multicolumn{6}{|c|}{ MEAN PREDATION (\%) } \\
\hline TEMPERATURE & 916.350 & 2 & 458.175 & 20.746 & 0.000 \\
\hline DENSITY & 9695.712 & 7 & 1385.102 & 62.717 & 0.000 \\
\hline $\begin{array}{l}\text { TEMPERATURE* } \\
\text { DENSITY }\end{array}$ & 1894.891 & 14 & 135.349 & 6.129 & 0.000 \\
\hline Error & 1590.104 & 72 & 22.085 & & \\
\hline \multicolumn{6}{|c|}{ MEAN ADULT WEIGHT } \\
\hline TEMPERATURE & 1788.418 & 2 & 894.209 & 5.952 & 0.004 \\
\hline DENSITY & 18039.902 & 7 & 2577.129 & 17.154 & 0.000 \\
\hline $\begin{array}{l}\text { TEMPERATURE* } \\
\text { DENSITY }\end{array}$ & 2564.825 & 14 & 183.202 & 1.219 & 0.281 \\
\hline Error & 10817.140 & 72 & 150.238 & & \\
\hline
\end{tabular}

* Significance level within the same rows by ANOVA

Table1. ANOVA of the effects of temperature and prey density on predation and development parameters of Eocanthecona furcellata 


\section{Effect of high constant temperatures on the development, mortality and prey consumption of Eocanthecona furcellata}

Nymphal development of E. furcellata was significantly affected by the tested extreme temperatures $(\mathrm{df}=3 ; \mathrm{F}=10.73 ; \mathrm{P}=0.000)$. The $2^{\text {nd }}$ instars $E$. furcellata survived for 12.6 ( \pm 0.40$)$ days at $15^{\circ} \mathrm{C}$ and $E$. furcellata did only survive for one day at $40^{\circ} \mathrm{C}$ and all $E$. furcellata died during moulting during the $2^{\text {nd }}$ instar to the $3^{\text {rd }}$ instar at both temperatures (Fig. 7). $50 \%$ and $90 \%$ of the predator nymphs were able to develop successfully and reach the adult stage ( $2^{\text {nd }}$ instar to adult) on average after $26.0( \pm 3.26)$ and $8.45( \pm 0.31)$ days at $20^{\circ} \mathrm{C}$ and $37^{\circ} \mathrm{C}$. Adults were able to survive for $69.2( \pm 1.24)$ days at $20^{\circ} \mathrm{C}$ and $12.67( \pm 0.58)$ days at $37^{\circ} \mathrm{C}$ (Fig. 8 and 9). E. furcellata was able to survive at these two constant temperatures; however $E$. furcellata was unable to lay eggs at $20^{\circ} \mathrm{C}$ and even though $E$. furcellata females deposited on average $14.8( \pm 3.2)$ eggs per batch at $37^{\circ} \mathrm{C}$, these eggs failed to begin embryonic development (Fig. 10). Thus, no viable offspring was recorded at the four tested extreme temperatures.

Regarding the average daily prey consumption of $E$. furcellata on Diamondback moth larvae, the effect of temperature and nymph instars were significant (df $=3$; $F=55.79 ; P=0.000)$ and $(d f=4 ; F=20.34 ; P=0.000) ;(F i g .11)$. At the lower temperature $\left(15^{\circ} \mathrm{C}\right)$ and the higher temperature $\left(40^{\circ} \mathrm{C}\right), 2^{\text {nd }}$ instar $E$. furcellata nymph consumed $0.355( \pm 0.32)$ and $0.30( \pm 0.18)$ larvae per day and all $2^{\text {nd }}$ instar nymphs used at $15^{\circ} \mathrm{C}$ and $40^{\circ} \mathrm{C}$ died even moulting to $3^{\text {th }}$ nymph instar. At $20^{\circ} \mathrm{C}$, E. furcellata nymph daily consumed 2.35 ( \pm 0.11$), 2.26( \pm 0.20), 2.62( \pm 0.23), 3.96$ $( \pm 0.29)$, and $2.35( \pm 0.18)$ Diamondback moth larvae for $1^{\text {st }}, 2^{\text {nd }}, 3^{\text {rd }}, 4^{\text {th }}, 5^{\text {th }}$ instar E. furcellata nymph and adult ( $\mathrm{df}=4 ; \mathrm{F}=10.39 ; \mathrm{P}=0.000)$. A slightly higher consumption was found when tested $5^{\text {th }}$ instar nymphs at $20^{\circ} \mathrm{C}$. The daily prey consumption by $E$. furcellata at $37^{\circ} \mathrm{C}$ gradually increased with $E$. furcellata instars, where it was $5.90( \pm 0.53)$ Diamondback moth larvae for $2^{\text {nd }}$ instar $E$. furcellata nymph and reached up to 23.09 ( \pm 0.61) Diamondback moth larvae for adult $E$. furcellata ( $\mathrm{df}=4 ; \mathrm{F}=163.13 ; \mathrm{P}=0.000) ;(F i g .11)$. During their entire lifespan, one 
E. furcellata was able to consume up to 260.00 ( \pm 16.56 ) larvae at $20^{\circ} \mathrm{C}$ and 388.89 ( \pm 8.20$)$ larvae at $37^{\circ} \mathrm{C}$ (Fig. 12).

Adult weight of $E$. furcellata was significantly affected by temperature and gender $(\mathrm{df}=1 ; \mathrm{F}=14.52 ; \mathrm{P}=0.002)$; and $(\mathrm{df}=1 ; \mathrm{F}=14.52 ; \mathrm{P}=0.036) ;($ Fig. 13). Female weight of E. furcellata $(87.0( \pm 8.20)$ and $118.96( \pm 3.25) \mathrm{mg})$ was heavier than that of the male $(68.28( \pm 1.32)$ and $76.3( \pm 8.70) \mathrm{mg})$ at $20^{\circ} \mathrm{C}$ and $37^{\circ} \mathrm{C}$.

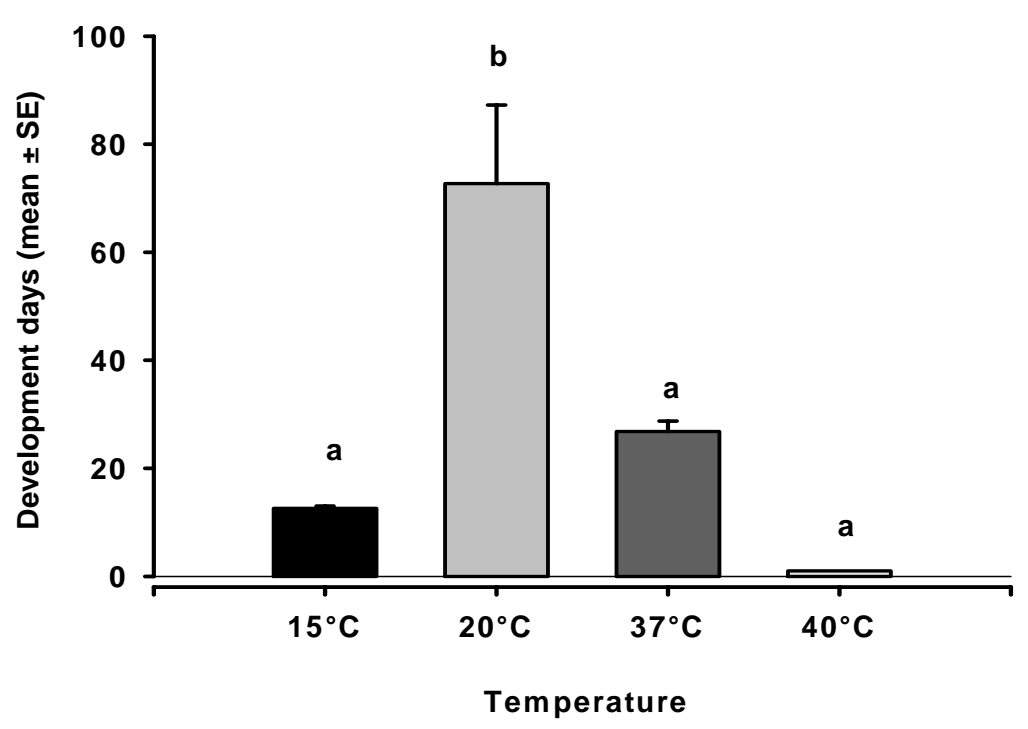

Figure 7: Longevity of Eocanthecona furcellata at different temperatures. Different letters indicate significant differences at $\mathrm{P}<0.01$ with Bonferroni adjustment after ANOVA. 


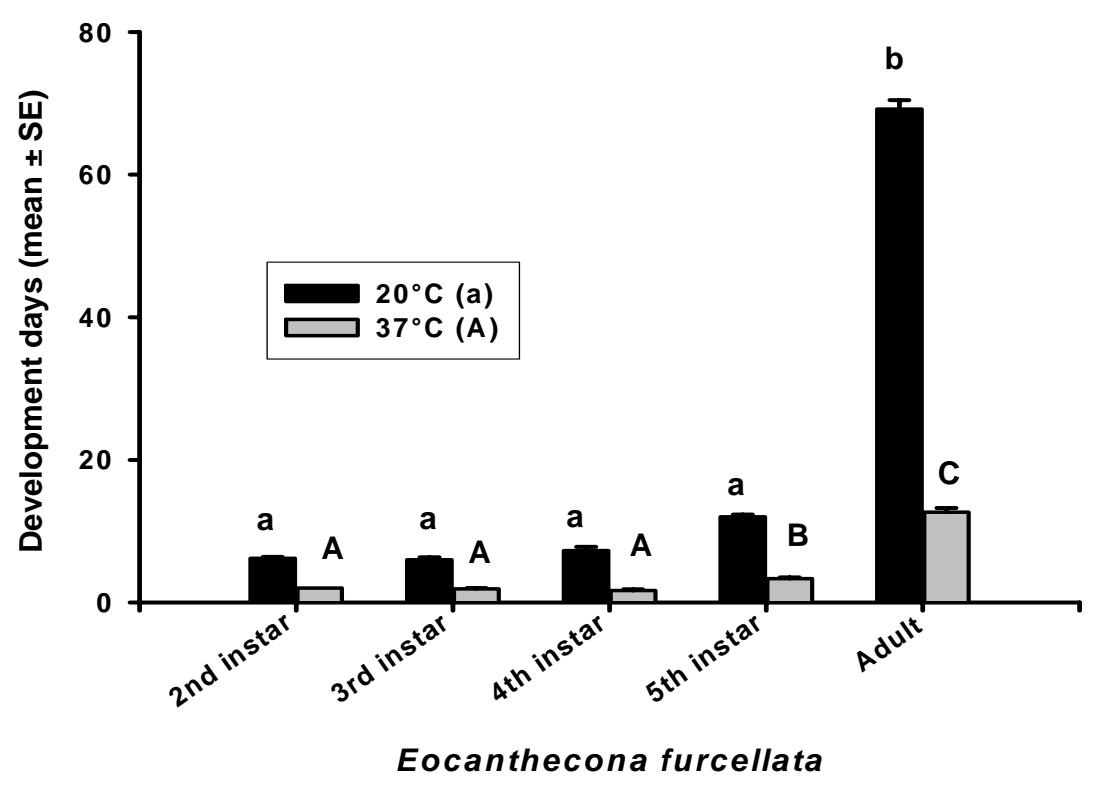

Figure 8: Developmental time of Eocanthecona furcellata from the $2^{\text {nd }}$ instar to adult at different temperatures. Different letters indicate significant differences at $P$ $<0.01$ with Bonferroni adjustment after ANOVA.

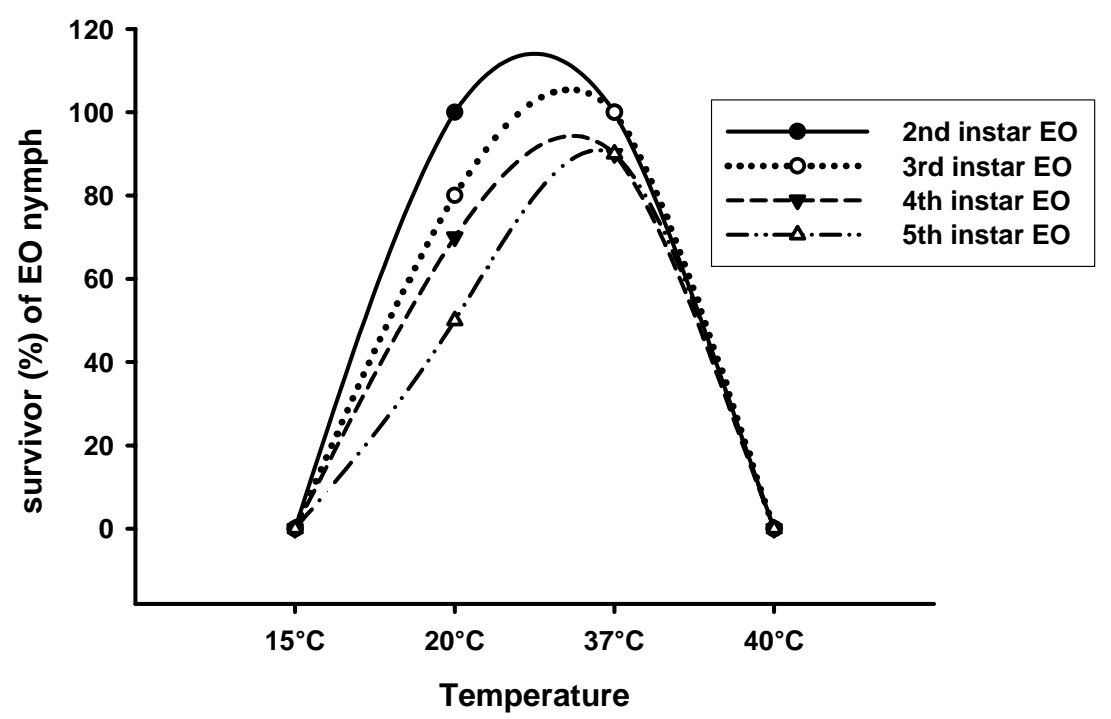

Figure 9: Percent surviving E. furcellata (EO) from the $2^{\text {nd }}$ instar to $5^{\text {th }}$ instar at different temperatures. 

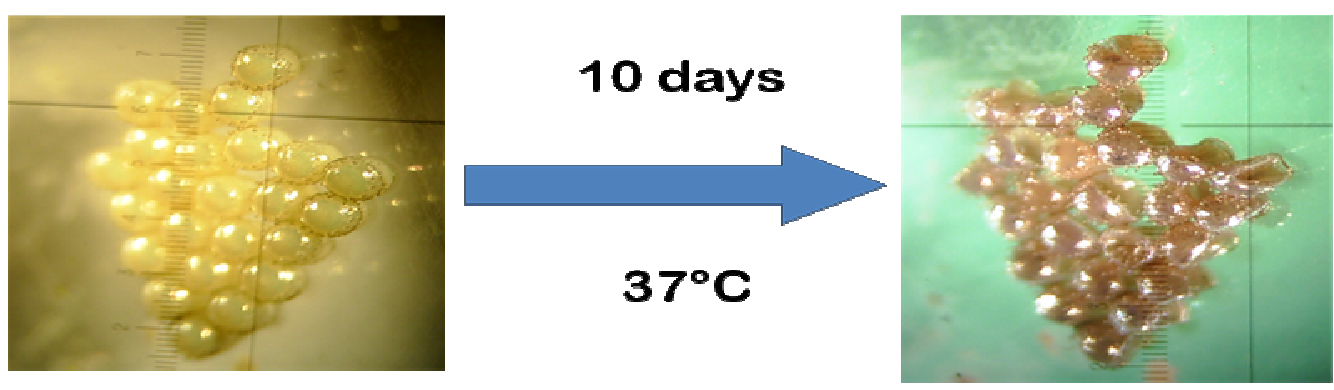

Figure 10: Eocanthecona furcellata eggs that failed to begin embryonic development at $37^{\circ} \mathrm{C}$

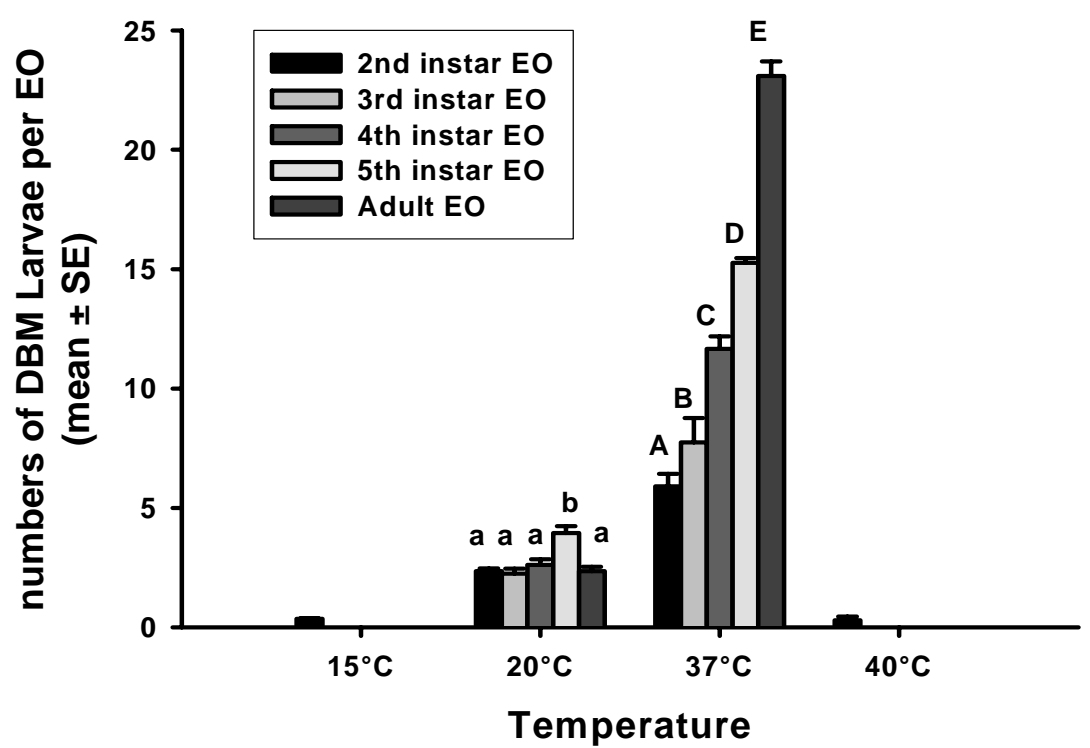

Figure 11: Daily consumption of $2^{\text {nd }}$ instar E. furcellata (EO) nymphs on Diamondback moth larvae at different temperatures. Different letters indicate significant differences at $\mathrm{P}<0.01$ with Bonferroni adjustment after ANOVA. 


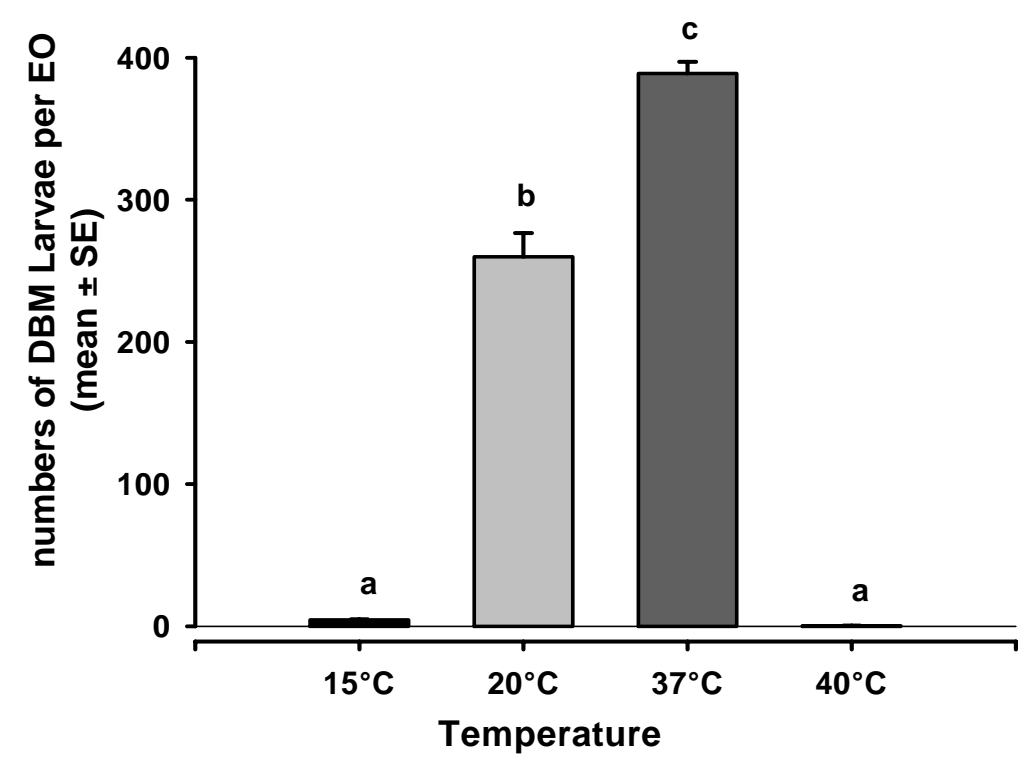

Figure 12: Total consumption of $2^{\text {nd }}$ instar E. furcellata nymph on Diamondback moth (DBM) larvae at different temperatures. Different letters indicate significant differences at $\mathrm{P}<0.01$ with Bonferroni adjustment after ANOVA.

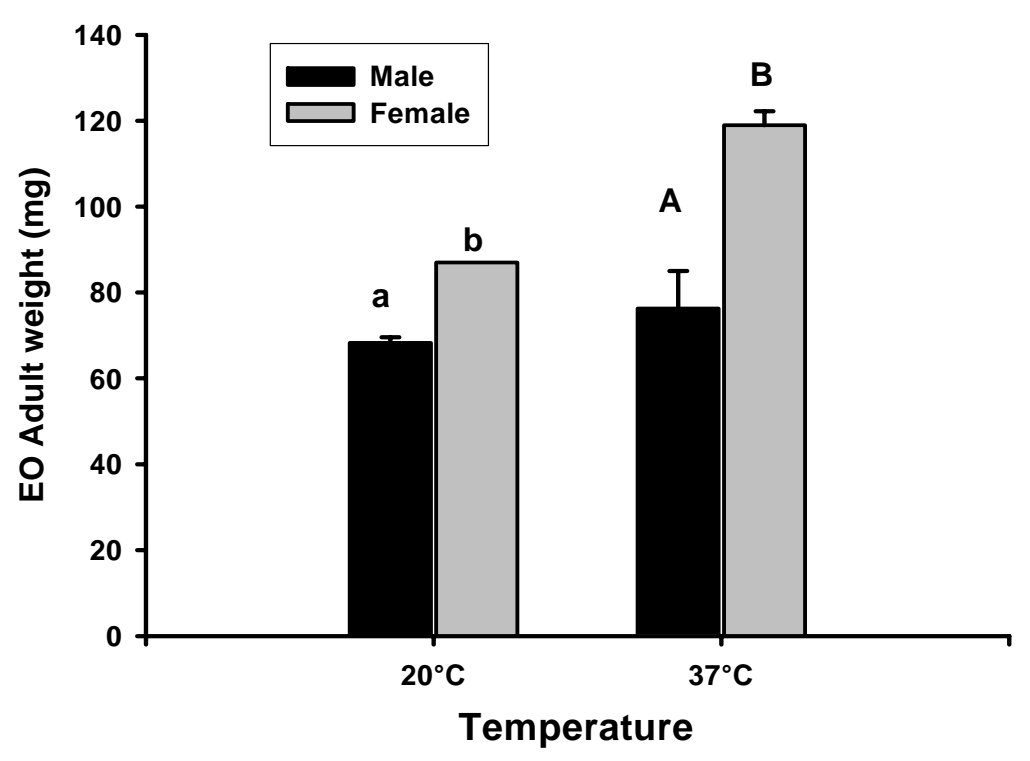

Figure 13: Adult weight of Eocanthecona furcellata (EO) developing at different temperatures. Different letters indicate significant differences at $P<0.01$ with Bonferroni adjustment after ANOVA. 


\section{DISCUSSION}

The results of the experiments indicate that E. furcellata successfully fed and completed its development at the temperatures $\left(25^{\circ} \mathrm{C}, 30^{\circ} \mathrm{C}\right.$, and $\left.35^{\circ} \mathrm{C}\right)$ tested irrespective to the prey density tests. The average developmental period was significantly shorter at higher temperatures $\left(35^{\circ} \mathrm{C}\right)$. These results correspond to Chang (2001) and also agreed with the results of previous studies on Podisus maculiventris ( De Clercq and Degheele, 1992; Mohaghegh et. al., 2001 and Legaspi, 2004); on Podisus nigrispinus (De Clercq and Degheele, 1992 and Medeiros et. al., 2003); on Rhyzobius lophanthae (Stathas, 2000); and on Scymnus levaiillanti (Uygun and Atlihan, 2000). Nymph developmental times decreased when increasing the prey densities up to 10 Diamondback moth larvae. The interaction of temperature and prey densities also affected the longevity of $E$. furcellata. The shortest nymphal developmental time (egg to adult) was found doubling at $35^{\circ} \mathrm{C}$ when 10 Diamondback moth larvae were offered daily and the longest was at $25^{\circ} \mathrm{C}$ fed with only 1 Diamondback moth larva. Adults were able to survive longer when temperatures were lower. The total developmental time of $E$. furcellata (egg to mortality of adults) was two times longer at $25^{\circ} \mathrm{C}$ than at $35^{\circ} \mathrm{C}$. When E. furcellata had sufficient prey, they may produce up to 11 generations per year. This is an important result with regard to potential biological control measures in hot countries like Myanmar.

Successful biological control of a pest is based on the fact that the natural enemy kills a sufficient number of preys to keep its density at low levels. Daily prey consumption of $E$. furcellata on Diamondback moth larvae increased gradually with increasing prey density. The highest amount of daily prey consumption per $5^{\text {th }}$ instar nymph of $E$. furcellata was found at $30^{\circ} \mathrm{C}$ when we offered 10 Diamondback moth larvae. Similar results were found by Saleh et.al. (2003) for prey consumption of Dicyphus tamaninii Wagner (Het., Miridae) with Aphis gossypii Glover at $30^{\circ} \mathrm{C}$. Prey consumtion decreased at higher temperature $\left(35^{\circ} \mathrm{C}\right)$ where $\mathrm{E}$. furcellata was only able to consume a minimum of Diamondback moth larvae, whereas the maximum (about 10 times) was found at $25^{\circ} \mathrm{C}$. This indicates that $E$. furcellata is 
adapted to tropical temperature regimes, as compared to the prey consumption in the predatory stink bugs $P$. bidens and $P$. maculiventris which was highest at $23^{\circ} \mathrm{C}$ (Mahdian et. al., 2006)

Functional responses describe the trend in which the number of prey consumed per predator changes with changes in prey density (Solomon, 1949). Predation rates of $E$. furcellata on Diamondback moth larvae increased with nymphal instars; the highest predation rate was recorded for the $5^{\text {th }}$ nymphal instar of $E$. furcellata at all tested temperatures. The most favorable predation rate was found at $30^{\circ} \mathrm{C}$ with regard to the $4^{\text {th }}$ and $5^{\text {th }}$ nymphal instars of $E$. furcellata and daily prey consumption of $4^{\text {th }} \& 5^{\text {th }}$ instars of $E$. furcellata nymphs is regarded sufficient for mass releasing purposes in biological control strategies. High predation rates of $P$. bidens were found at a wide range of temperatures (Mahdian et. al.,2006). Therefore it is suggested that this species may be a valuable asset for the biological control of Diamondback moth, provided that obstacles to its mass production can be overcome.

Statistical analyses revealed that temperature and prey density as well as their interactions were significantly effecting adult weight. The adult weight of $E$. furcellata increased when increasing the prey density. The gender also affected the adult weight at three tested temperature, with the female being heavier and bigger than males.

The result of the experiments conducted on the effect of extreme temperatures on the development of E. furcellata showed that $50 \%$ and $90 \%$ from $2^{\text {nd }}$ instar developed to adult the stage at constant temperatures of $20^{\circ} \mathrm{C}$ and $37^{\circ} \mathrm{C}$, respectively. E. furcellata was able to survive at these two constant temperatures; however $E$. furcellata was unable to lay eggs at $20^{\circ} \mathrm{C}$ and even though they laid eggs at $37^{\circ} \mathrm{C}$, no larvae hatched to nymphs. The $2^{\text {nd }}$ instars $E$. furcellata survived for $12.6( \pm 0.40)$ days at $15^{\circ} \mathrm{C}$ and $E$. furcellata did only survive for one day at $40^{\circ} \mathrm{C}$ and all $E$. furcellata died during moulting from $2^{\text {nd }}$ instar to $3^{\text {rd }}$ instar nymphal stage at both temperatures. Therefore no viable offspring was recorded in the four tested 
extreme temperatures. We regard the low temperature threshold for E. furcellata at $15^{\circ} \mathrm{C}$ and high temperature threshold at $40^{\circ} \mathrm{C}$.

Adult weight of $E$. furcellata was significantly affected by temperature and gender; female weight of $E$. furcellata was heavier than male weight at $20^{\circ} \mathrm{C}$ and $37^{\circ} \mathrm{C}$. Effects of extreme temperatures can lead to failure of an IPM strategy that may be quite effective in a narrow temperature range (Horn, 1998). Biological control agents, especially arthropod natural enemies, often exhibit temperature optima different from those of their prey, and may become ineffective at higher or lower temperatures.

As a result E. furcellata seems to be adapted to climatic conditions prevailing in the tropical regions. Given these preferences E. furcellata may be used for biological control purposes only in areas with mean temperatures of above $25^{\circ} \mathrm{C}$.

\section{REFERENCE}

Ahmad M., A. P. Singh, S. Sharma, R. K. Mishra and M. J. Ahmad (1996) Potential estimation of the predatory bug Canthecona furcellata Wolff (Hemiptera: Pentatomidae) against popular defoliator Clostera cupreata (Lepidoptera: Notodontidae). Annals of Forestry 4: 133-138

Bell P.D., P.G Fenemore (1990) Insecticide resistance in diamondback moth in New Zealand. Proceeding of the 43th New Zealand Plant Protection Conferences: 31-34

Capinera JL. (2001) Handbook of Vegetable Pests. Academic Press, San Diego. 729 pp.

Chang, C-P. (2001) Predatory capacity of the predatory stink bug Eocanthecona furcellata (Wolff) (Hemiptera: Pentatomidae) on various prey. Formosan Entomologist 21: 257-267 (in Chinese with English abstract) 
Chang, C-P. (2002) Mass rearing and utilization of the predatory stink bug Eocanthecona furcellata. Formosan Entomologist 3: 175-181 (in Chinese with English abstract)

Chu, Y. (1975) Rearing density of Eocanthecona furcellata, with special consideration to its mass production (Asopinae: Pentatomidae). Rostria 24: 135-140 (in Japanese with English abstract)

De Clercq, P. and D. Degheele. (1990) Effects of temperature and relative humidity on the reproduction of the predatory bug Podisus sagitta (Fab.) (Heteroptera: Pentatomidae). Mededelingen Faculteit Landbouwwetenschappen Rijksuniversiteit Gent 55: 439-443

De Clercq, P. and D. Degheele (1992) Development and survival of Podisus maculiventris (Say) and Podisus sagitta (Fab.) (Heteroptera: Pentatomidae) at various constant temperatures. Can. Entomol., 124: 125-133

Endersby, N. and P. Ridland (1994) Insecticide resistance in Victorian populations of diamondback moth, Plutella xylostella (L.). Australian Entomological Society Conference, Abstract, 31.

Gillham, F.E.M. (1980) Introduction to cotton insect pest control in Burma. Seed development project report no. 22. Ministry of Agriculture and Forests, Rangoon, Burma. 77pp.

Hassell, M.P. (1985) Insect natural enemies as regulation factors. J. Anim. Ecol. 54: $323-334$

Harcourt, D. G. (1957) Biology of the Diamondback Moth, Plutella maculipennis (Curt.) (Lepidoptera: Plutellidae), in Eastern Ontario. II. Life-History, Behavior, and Host Relationships. Can. Entomol. 89: 554-564.

Ho, H.-Y., R. Kou, and H.-K. Tseng (2003) Semiochemicals from the predatory stink bug Eocanthecona furcellta (Wolff): components of metathoracic gland, 
dorsal abdominal gland, and sternal gland secretions, J. of Che Eco 29(9): 2101-2114

Horn, D. J.(1998) Temperature Synergism in Integrated Pest Management, in Temperature sensitivity in insects and application in integrated pest management edited by Guy J. Hallman and David L. Denlinger. Westview Press, 311p.

Jakhmola, S. S. 1983. Natural enemies of Til leafroller and capsuleborer, Antigastra catalaunalis (Dup.). Bull. Entomol. 24 (2): 147-148.

Khin Thein Nyunt (2001) Impact of planting dates on the population of cotton pests and natural enemies in Myanmar. M.Sc.agr. thesis at Georg-AugustUniversity, Goettingen, Germany. 99 p.

Legaspi, J. C. (2004) Life history of Podisus maculiventris (Heteroptera: Pentatomidae) adult females under different constant temperatures, Environ. Entomol. 33 (5): 1200-1206

Mahdian, K., I. Vantornhout, L. Tirry and P. De Clercq (2006) Effects of temperature on predation by the stinkbugs Picromerus bidens and Podisus maculiventris (Heteroptera: Pentatomidae) on noctuid caterpillars. Bull. Entomol Res 96:489-496

Medeiros, R. S., F.S. Ramalho, J. C. Zanuncio, and J. E: Serrao (2003a) Effect of temperature on life table parameters of Podisus nigrispinus (Het.: Pentatomidae) feb with Alabama argillacea (Lepidoptera: Notodontidae) larvae, J. Appl. Ent: 127: 209-213

Medeiros, R. S., F.S. Ramalho, J. E: Serrao, and J. C. Zanuncio (2003b) Temperature influence on reproduction of Podisus nigrispinus, a predator of the noctuid larva Alabama argillacea. Biocontrol 48: 695-704

Mohaghegh, J., P. De Clercq, and L. Tirry (2001) Functional response of the predators Podisus maculiventris (Say) and Podisus nigrispinus (Dallas) 
(Het.: Pentatomidae) to the beet armyworm, Spodoptera exigua (Hübner) (Het.: Pentatomidae): effect of temperature

Morris, H. and D. F. Waterhouse (2001) The distribution and important of arthropod pest and weeds of agriculture in Myanmar. ACIAR Monograph No. 67,73 pp.

$\mathrm{Nu} \mathrm{Nu}$ Yi and Win Kyi (2000) Biological control of cotton bollworm and chickpea pod borer, Helicoverpa armigera y using predator Eocanthecona furcellata and parasitoid Campoletis chlorideae. In proceeding of the annual research conference, April 3-5, 2000, Yangon, Myanmar. 58-74 pp.

Prasad, D., K. M. Singh, R. N. Singh, and D. N. Mehto (1983) A new predator of new pest of jasmine in Delhi. Bull. Entomol. 24: 140-141.

Saleh, A. and C. Sengonca (2003) Effects of different high constant and alternating temperatures on the development and prey consumption of Dicyphus tamaninii Wagner (Heteroptera, Miridae) with Aphis gossypii Glover (Homoptera, Aphididae) as prey. Journal of Pest Science 76(5): 118-123

Saxena, J.D., S. Rai, K.M. Srivastava \& S.R. Sinha (1989) Resistance in the field population of the diamondback moth to some commonly used synthetic pyrethroids. Indian J. Entomol. 51: 265-268

SPSS Inc., (2004) Systat 11 for Windows; SPSS Inc., Chicago, USA.

Solomon, M. E.(1949) The natural control of animal populations. J. Anim. Ecol. 18: 1-35

Stathas, G. J. (2000) The effect of temperature on the development of the predator Rhyzobius lophanthae and its phenoloy in Greece, Biocontrol 45: 439-451

Sun C-N (1992) Insecticide resistance in diamondback moth. In: Talekar NS ed. Diamondback moth and other crucifera pests. Proceedings of the 2nd International Workshop, Taiwan, December 1990, AVRDC publication. 419$426 \mathrm{pp}$. 
Tabashnik B. E., N. L. Cushing, M. W. Johnson (1987) Diamondback moth (Lepidoptera: Plutellidae) resistance to insecticides in Hawaii: Intra-island variation and cross-resistance. J. Econ. Entomol. 80: 1091-1099.

Talekar, N.S. and Shelton, A.M. (1993) Biology, ecology and management of diamondback moth. Ann Rev of Entomol. 38: 275-301.

Torres, J. B., J.C. Zanuncio and H.N. Oliveira (1998) Nymphal development and adult reproduction of the stinkbug predator Podisus nigrispinus (Heteroptera: Pentatomidae) under fluctuating temperatures. J. Appl. Entomol. 122: 509514

Uygun, N. and R. Atlihan (2000) The effect of temperature on development and fecundity of Scymnus levaillanti. Biocontrol 45: 453-462

Voice, D.G. and Chapman, R.B. (2000) Imported insecticide resistance in diamondback moth. New Zealand Plant Protection, 53, 83-86.

Yasuda, T. and S. Wakamura (1992) Rearing of the predatory stink bug Eocanthecona furcellata (Wolff) (Hemiptera: Pentatomidae), on frozen larvae of Spodoptera litura (Fabricius) (Lepidoptera: Noctuidae). Appl. Entomol. Zool., 27:303-305 


\section{Chapter 3}

\section{Prey searching and feeding behavior of Eocanthecona furcellata Wolff (Hemiptera: Pentatomidae on different prey items, host plant species and plant status}

\section{ABSTRACT}

The predatory stink bug Eocanthecona furcellata Wolff (Hemiptera: Pentatomidae (EO), native to Southeast Asia offers potential to be used as a biological control agent against lepidopteran pests. However, in order to establish the biocontrol agent the prey searching and feeding behavior of EO has to be evaluated in detail. We investigated the effect of two different prey items (American bollworm ABW and Diamondback moth (DBM), feeding on different host plants (cotton and cabbage plants) subject to different treatments under laboratory condition and green house conditions.

Searching time and prey consumption time of EO was significantly longer with regard to DBM ( $70.78 \pm 2.84$ minutes) as compared to ABW (36.75 \pm 3.96 minutes) on cabbage plants. Under laboratory conditions, EO was able in a second to locate the prey items and needed $36.73 \pm 2.57$ minutes for consuming DBM as compared to $15.1 \pm 0.98)$ minutes to consume ABW.

When ABW larvae were offered on cotton leaves EO neede less time $(24.2 \pm 1.91$ minutes) to locate the prey items than on cabbage leaves ( $36.75 \pm 3.961$ minutes). Mean prey consumption time of EO on ABW larvae was not different between both plant species tested; however prey consumption under laboratory conditions was three times faster than on the plants.

EO visits on cotton and cabbage plants were distinctly shorter as compared to insect infested plants and visiting time of EO on ABW infested cotton plants were half than on DBM infested cabbage plants. EO was attracted more by ABW than DBM and movement of EO was quicker on cotton plants. 
In a Y-olfacotmeter EO was attracted more by ABW than DBM larvae; however searching time of EO was not significantly different with regard to both larval species.

The results are discussed with regard to the potential of the predatory bug to be used as a biocontrol agents in cotton fields.

Keywords: Biological control, Cotton plant, Eocanthecona furcellata, Diamondback Moth, Myanmar

\section{INTRODUCTION}

The American bollworm (Helicoverpa armigera Hübner)(ABW) is the most severe pest of cotton and is gound in all agricultural regions and on all important crops in Myanmar (MCSE 1999, Morris and Waterhouse 2001). Due to its highly polyphagous feeding behaviour the pest has a wide distribution in the world (Commonwealth 1968; Hill 1975; Reed and Pawar 1982). The management of ABW is difficult and multiple insecticide applications have led to high levels of resistance to major groups of active compounds (Fitt 1989; Armes et al. 1996). To solve this problem, one promising approach could be to manage $\mathbf{A B W}$ by releasing natural enemies.

The Diamondback moth (Plutella xylostella Linnaeus)(DBM) is a major pest of vegetable brassicas in Myanmar (Morris and Waterhouse 2001). DBM populations in the major production regions are resistant to organophosphate, carbamate, pyrethroid and organochlorine insecticides in Hawaii (Tabashnik et al. 1987); India (Saxena et al. 1989); Australia (Endersby \& Ridland 1994); New Zealand (Bell and Fenemore 1990) and in South-East Asia, Japan, USA and Central America (see Sun 1992 fo a review). This problem has promted a decision to search for biological control options in controlling DBM in Myanmar.

The predatory bug (Eocanthecona furcellata Wolff)(EO) was found preying on ABW larvae in cotton and cauliflower fields in Myanmar (Gillham, 1980; Nu Nu Yi and Win Kyi, 2000, and Khin, 2001). EO was also found in Southeast Asia preying on other larvae of Lepidoptera, Coleoptera and Heteroptera (Ahmad 1996; Chu 
1975; Chang 2002; Jakhmola 1983; Prasad et. al. 1983). A laboratory evaluation of the efficacy of EO on lepidopteran pest resulted in a positive decision to release EO as a biocotrol agent to control ABW and DBM in Myanmar (Khin and Vidal 2006, and Khin and Vidal 2007a, Khin and Vidal 2007b). Prey location behavior of Eocanthecona furcellata was already studied by Yasuda \& Wakamura (1996) and Yasuda (2000). Bell (1990) found that the searching behavior of insects depended on the biological characteristics of the insect, internal factors and external environmental factors. Therefore, the predation behavior EO may change under field conditions and more studies are needed to understand prey searching and feeding behavior of the predatory bug EO with regard to specific plant conditions.

This study aims at testing the impact of two different prey items, two different host plant species ; and three different conditions of these plants on the behaviour of EO. Furthermore, searching and feeding behavior of EO was compared using either greenhouse conditions or Petri dishes.

\section{MATERIAL AND METHODS}

\section{Culture of insects}

Eggs and adults of the pentatomid Eocanthecona furcellata (Wolff) (Hemiptera: Pentatomidae) (EO) were originally collected in November 2004 in cotton fields in Myanmar. They were released in rearing cages $(75 \times 55 \times 75 \mathrm{~cm})$ and reared on Diamondback moth infested cabbage plants because of the high egg laying capacity of DBM adults. Eggs were transferred to Germany and EO was maintained at room temperature $\left(22 \pm 1^{\circ} \mathrm{C}\right)$ under laboratory conditions at the Entomology Section, Georg-August University, Goettingen, Germany. $5^{\text {th }}$ instars Nymph of EO were collected randomly from the rearing cage and individuals were maintained in Petri-dish and starved 24 hours before starting the experiments.

American bollworm (Helicoverpa armigera Hübner) (Lepidoptera: Noctuidae) (ABW) eggs were obtained from Bayer AG, Germany, and hatched larvae were reared on cabbage plants under laboratory condition and $6.00( \pm 1.00) \mathrm{mg}$ larvae were used for the experiments. 
A stock culture of Diamondback moth (Plutella xylostella Linnaeus)(DBM) larvae was maintained on cabbage plant in rearing cages at room temperature $\left(22 \pm 1{ }^{\circ} \mathrm{C}\right)$ under laboratory conditions and $6.00( \pm 1.00) \mathrm{mg}$ larvae were used for the experiments.

\section{Culture of plants}

Cotton (Gossypium hirsutum cv. MCU 9) and cabbage (Brassica orleracea var. viridis) were grown in controlled greenhouse conditions; plants were grown in 13 cm diameter pots (Sand: Clay 50: 50) for this experiments. Four- to six-weeks old plants, with four fully expanded true leaves were used in the experiments. Seeds of G. hirsutum cv. MCU 9 were provided from Myanmar and seeds of $B$. orleracea var. viridis from Germany.

\section{Effect of different preys}

Cabbage plants (Brassica orleracea var. viridis) at the four true leave stages were used as food sources for ABW and DBM larvae, respectively. $5^{\text {th }}$ instar larvae of starved EO nymphs were used in this experiment. Each treatment was replicated ten times. Each larva of DBM and ABW were weighed and $6.00( \pm 1.00) \mathrm{mg}$ larvae were placed on each leaf of 10 cabbage plants and also placed in 10 Petri-dishes for each insect. Larvae were allowed to settle on the leaves for 15 minutes. A single predator was released into the arena or on the plants and the searching time (including waiting time) and the time to consume the prey was recorded for each individual.

\section{Effect of different host plants}

Cotton plants (Gossypium hirsutum L.) and cabbage plants (Brassica orleracea var. viridis) at the four leave stage were used as food sources for ABW larvae. $5^{\text {th }}$ instars of starved EO nymphs were used in this treatment; these were offered two host plants and Petri-dishes and each treatment was replicated ten times. Each larva of ABW was weighed and $6.00( \pm 1.00) \mathrm{mg}$ larvae were placed on each leaf of both host plants and allowed to settle on the leaves for 15 minutes. A single 
predator was released into the arena and the searching time (including waiting) and the time to consume the prey of EO was recorded for each individual.

\section{Effect of different host plant conditions}

30 Cotton plants and 30 cabbage plants at the four leave stage were used for this experiment; 10 of each host plants were used as control plants, another 10 of each host plants were cut with a pair of scissors and used as wounded plants, and the remaining 10 cotton and cabbage plants were used as insect infected plants. ABW larvae were placed on each leaf of these plants and were allowed to settle for 15 minutes on the leaves. Thereafter ABW larvae were removed from the plants and the plants were used for the experiment. A single $5^{\text {th }}$ instar nymph of EO was released into the arena and the visiting time of EO for each ABW individual was recorded.

\section{Prey selecting behavior of Eocanthecona furcellata towards American bollworm and Diamondback moth larvae in an Y-olfactometer}

This experiment aimed at understanding the host selection behavior of EO towards larvae of ABW and DBM using a Y-shaped dual tube olfactometer (Fig. 17) at room temperature $22( \pm 1)^{\circ} \mathrm{C}$ with twenty replications. Both ABW and DBM larvae were reared on cabbage plants and ten $5^{\text {th }}$ instar EO nymphs were randomly selected from a rearing cage and starved for 24 hours. ABW and DBM larvae were placed in the alternative odor source tubes and a single EO was released into the starting point of the olfactometer and collected in the observation arena. If EO did not move within 5 minutes we regarded this as no choice; EO was then removed and replaced with another EO. We studied searching time (from starting point to observation area) percentage of EO either selecting DBM or ABW.. 


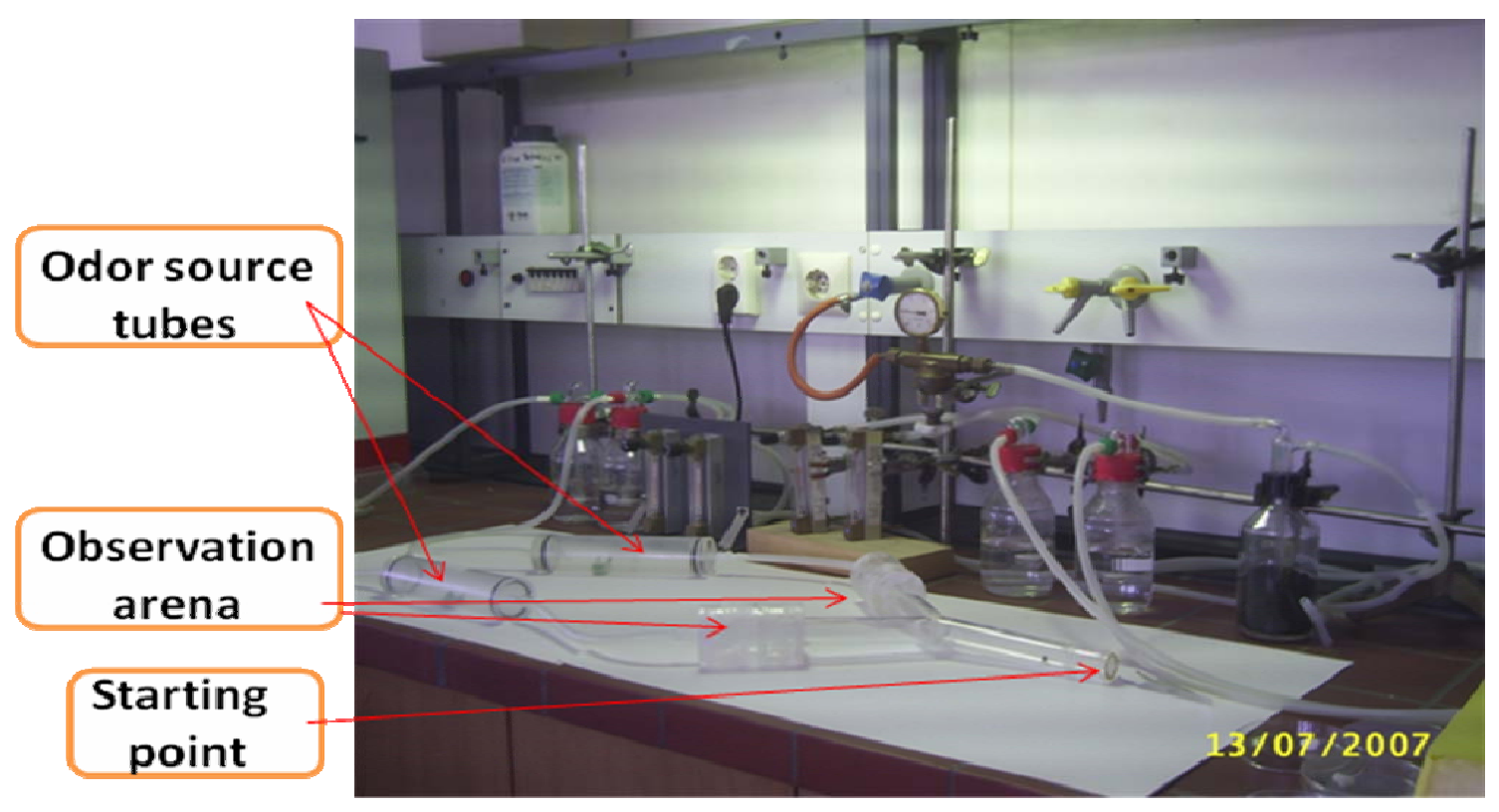

Figure 1: Y-shape dual tube Olfactometer

\section{Statistical analyses}

Data were analyzed using Analysis of variance (ANOVA) by SYSTAT 11 for Windows (SPSS Inc., 2004). We used a one-way analysis of variance (ANOVA) with a Fisher's Least-Significant-Different Test (LSD) to compare the individual samples of searching time and consuming time of EO for different preys, different host plants and different conditions against each other in pair wise comparisons.

\section{RESULTS}

\section{Effect of different preys}

When EO larvae were released onto the plants, $90 \%$ of them were able to search for and capture the prey larvae on the first leaf of the plants. Thereafter EO moved upwards on the plant. However, EO searching time for DBM larvae on the first leaf was significantly different $(\mathrm{df}=3 ; \mathrm{F}=7.119 ; \mathrm{P}=0.001)$ as compared to the other leaves on the cabbage plants; EO found the $1^{\text {st }}$ DBM larva within $32.10( \pm 4.21)$ minutes but $2^{\text {nd }}$ to $4^{\text {th }}$ DBM larvae were caught in $89.00( \pm 2.59)$ minutes. EO searching for DBM larvae was significantly different ( $d f=1 ; F=127.981 ; P=0.000)$ when comparing DBM larvae placed on host plants and offered in Petri dishes. EO 
needed only 1.30 ( \pm 0.058) seconds to locate DBM in Petri-dishes although the searching time of EO within the DBM larvae in the Petri dishes was not significantly different (df = 3; F=0.480; $P=0.698)$ (Fig. 1).

On the other hand, searching behavior of EO when exposed to ABW larvae was not statistically different on the plant ( $d f=3 ; F=0.913 ; P=0.446)$ and in a Petri dishes (df = 3; F= 0.025; P= 0.889). However EO searching for ABW larvae was significantly different $(\mathrm{df}=1 ; \mathrm{F}=241.768 ; \mathrm{P}=0.000)$ between $\mathrm{ABW}$ larvae placed on host plants as compared to larvae offered in Petri dishes. On cabbage plants, ABW larvae were found in 36.75 ( \pm 3.961$)$ minutes whereas EO took only 1.13 ( \pm 0.108) seconds in Petri-dishes for searching each ABW larva (Fig. 2).

Prey consumption time of EO larvae was significantly different on plants as compared to Petri-dishes with regard to both prey larvae; for DBM (df = 1; F= 99.868; $P=0.000$ ) and for $A B W(d f=1 ; F=282.276 ; P=0.000)$ (Fig. 3 and 4). No significant differences could be observed within larvae when offered ABW larvae on the plant $(\mathrm{df}=3 ; \mathrm{F}=0.707 ; \mathrm{P}=0.556)$ or in Petri dishes $(\mathrm{df}=3 ; \mathrm{F}=0.619 ; \mathrm{P}=$ 0.607 ) and also offered DBM larvae on the plant ( $d f=3 ; F=2.644 ; P=0.065$ ) although prey consumption time of EO for $1^{\text {st }}$ DBM larva was significantly longer than other DBM larvae in Petri dishes ( $d f=3 ; F=4.638 ; P=0.008$ ).

Prey searching time of EO for DBM larvae on the plants was two times longer than searching for $A B W$ larvae ( $d f=3 ; F=97.229 ; P=0.000$ ) (Fig. 5). EO needed only half time for consuming DBM and one third for ABW when prey was offered in Petri-dishes (df = 3; F= 88.574; P=0.000) (Fig. 6). 


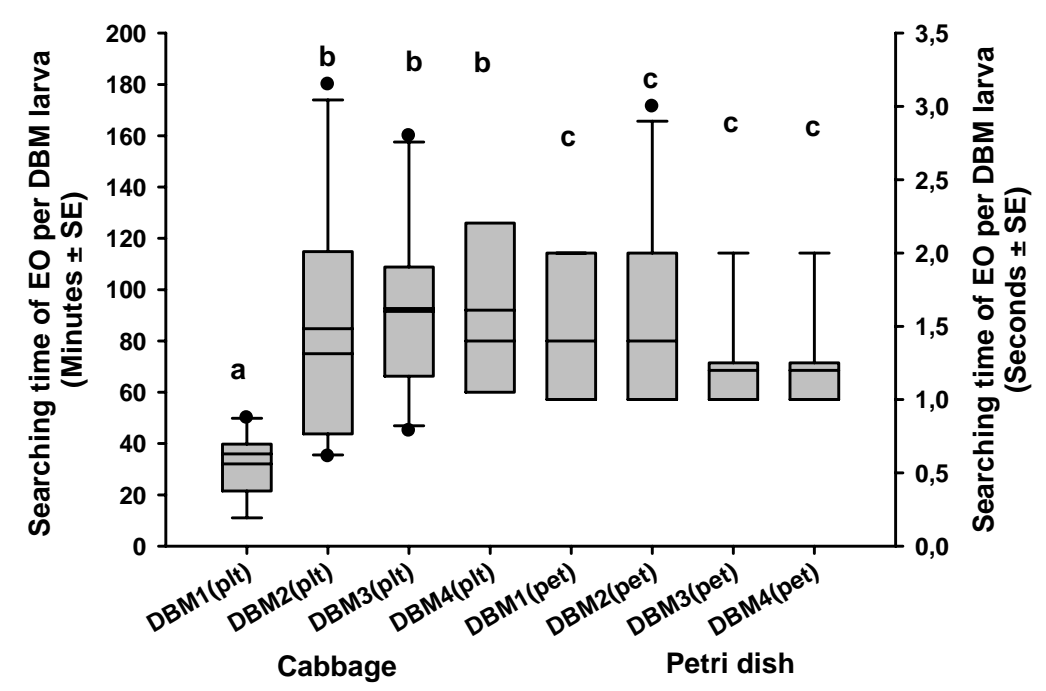

Figure 1: Searching time of EO for DBM larvae either placed on different leaves on the cabbage plants (plt - in minutes) or offered in Petri dishes (pet - in seconds). Same letters indicate no significant differences at $P<0.01$ for Fisher's LSD test after ANOVA.

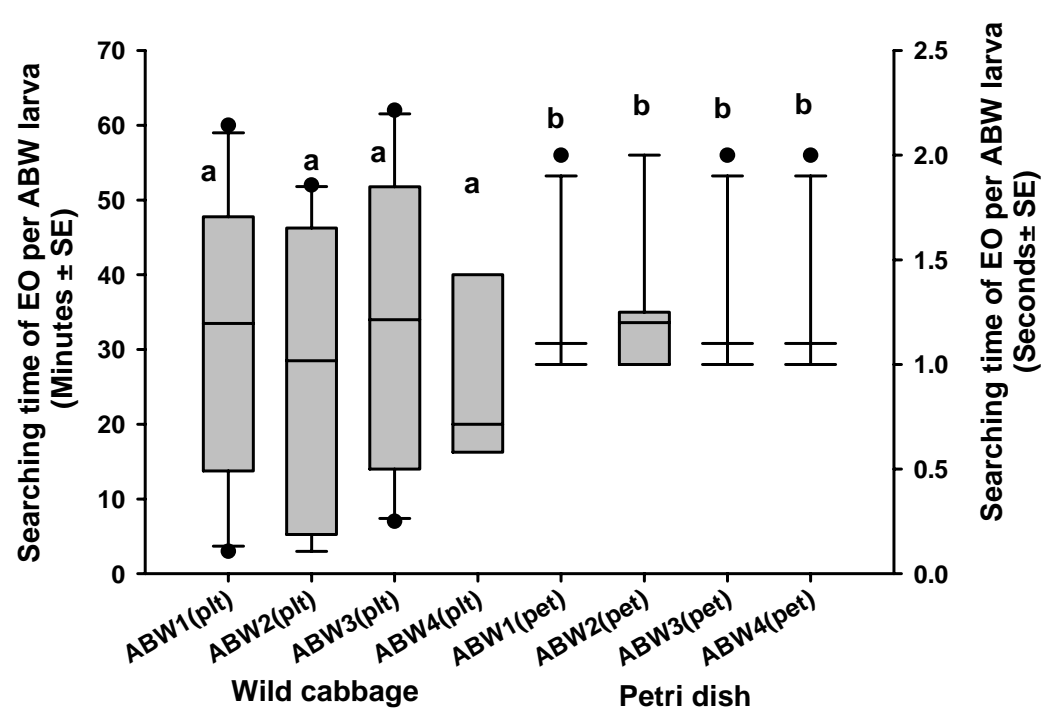

Figure 2: Searching time of EO for ABW larvae either placed on different leaves on the cabbage plants or offered in a Petri dish. Same letters indicate no significant differences at $\mathrm{P}<0.01$ for Fisher's PLSD test after ANOVA. 


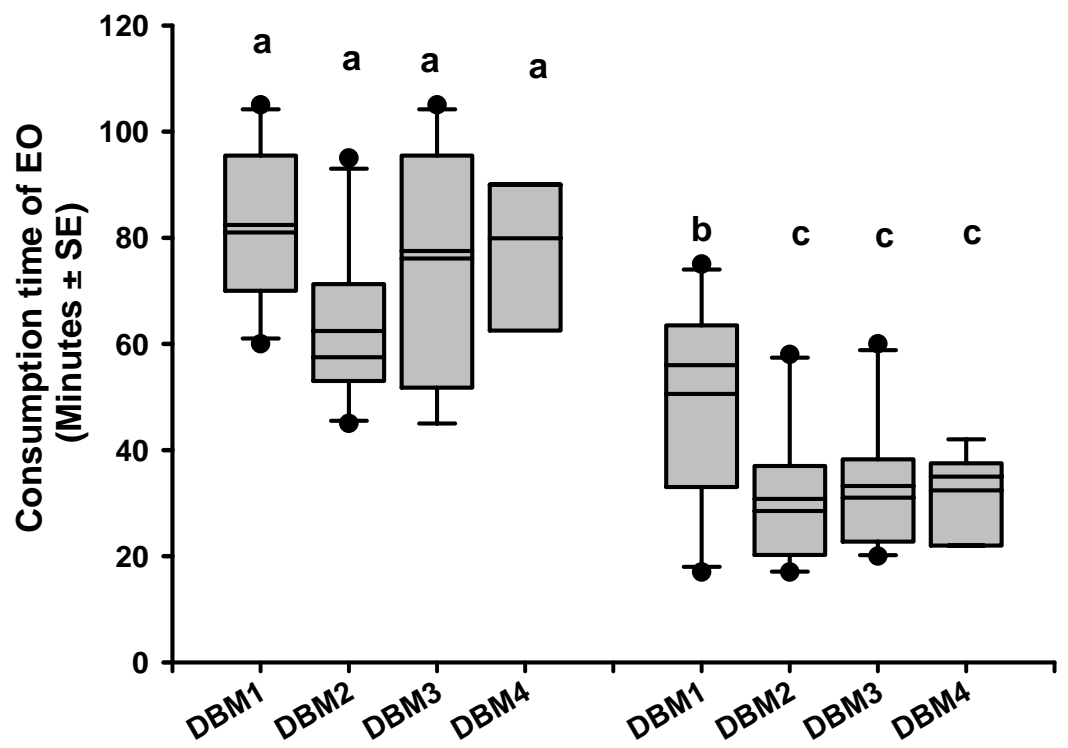

Wild cabbage

Petri dish

Figure 3: Consumption time of EO when offered DBM larvae either placed on different leaves on the cabbage plants or in a Petri dish. Same letters indicate no significant differences and different letters indicate significant differences at $\mathrm{P}<$ 0.01 for Fisher's LSD test after ANOVA.

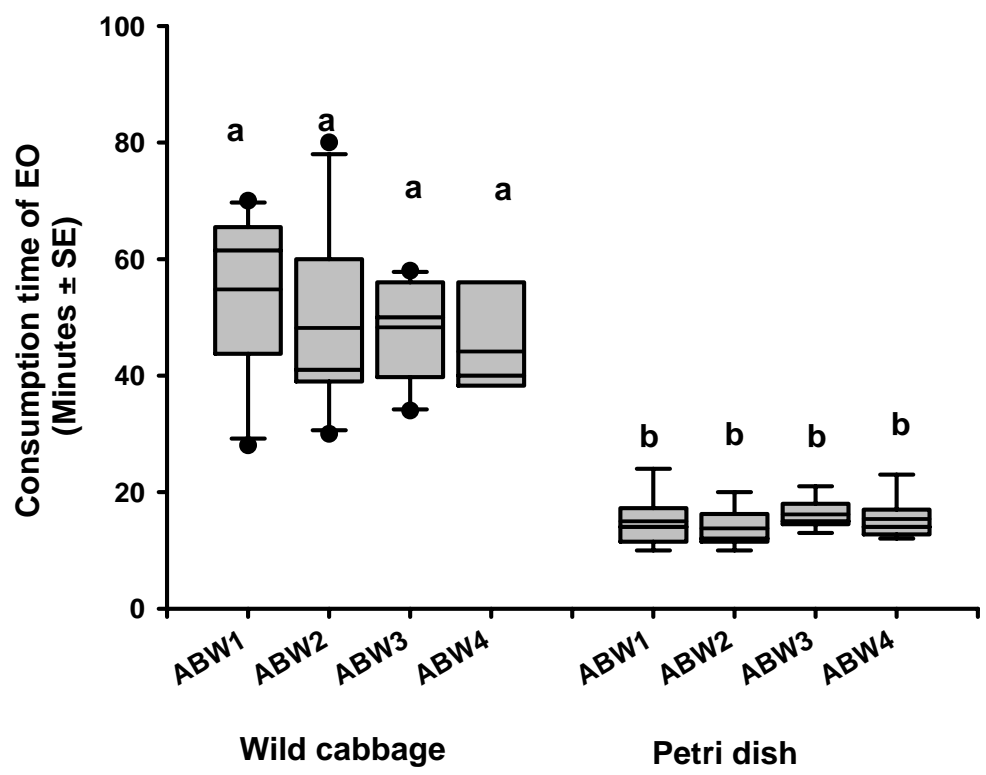


Figure 4: Consumption time of EO when offered ABW larvae either placed on different leaves on the cabbage plants or in a Petri dish. Same letters indicate no significant differences at $\mathrm{P}<0.01$ for Fisher's LSD test after ANOVA.

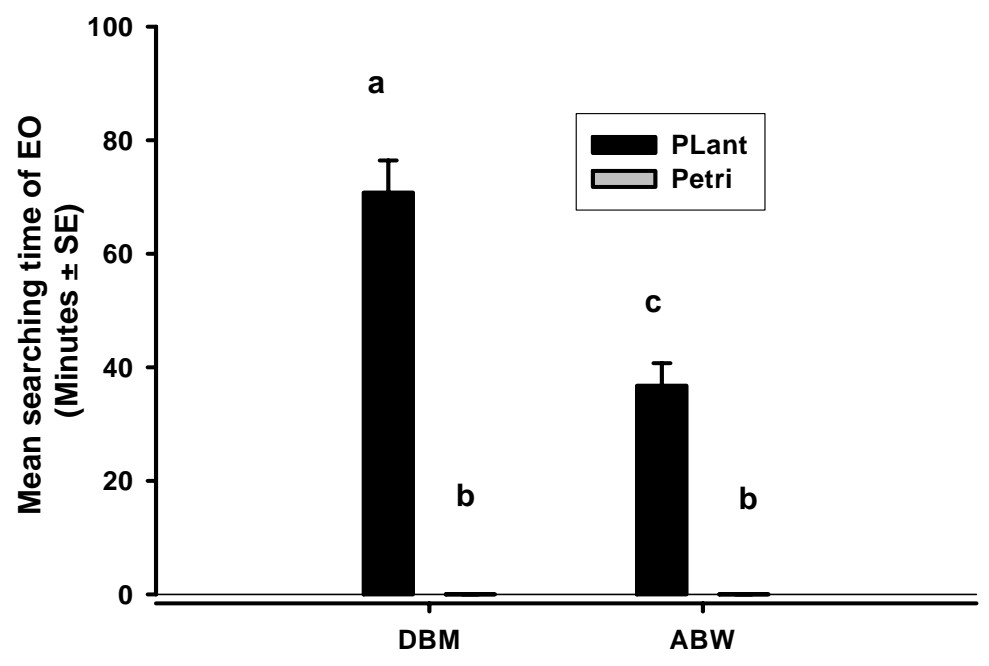

Figure 5: Mean searching time of EO when offered DBM larvae or ABW larvae on the plants and in a Petri dish. Different letters indicate significant differences at $\mathrm{P}<$ 0.01 for Fisher's LSD test after ANOVA.

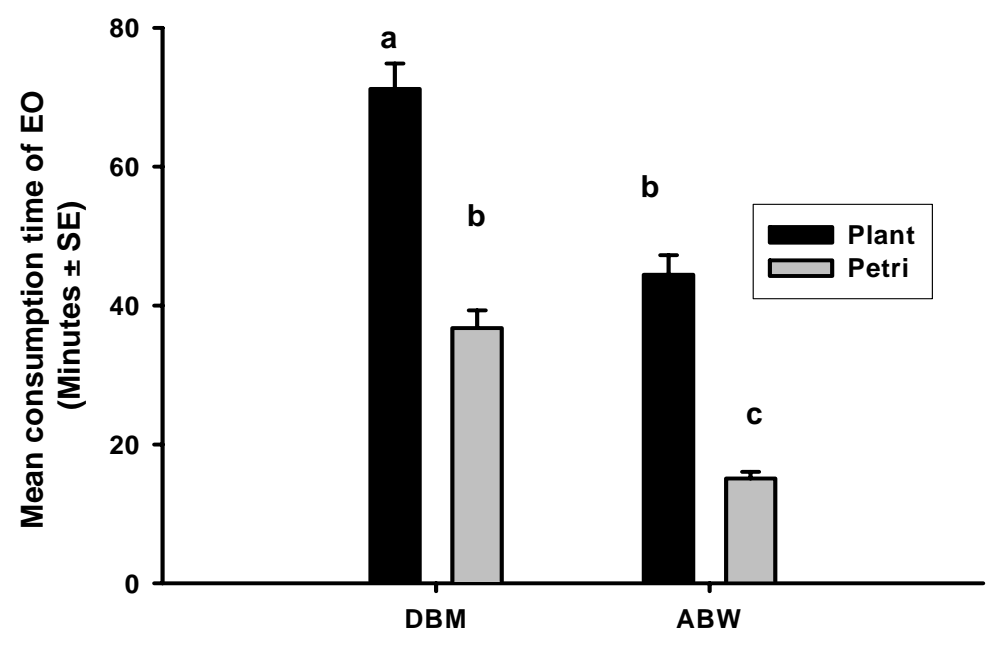

Figure 6: Mean consumption time of EO when offered DBM larvae or ABW larvae on the plants and in a Petri dish. Different letters indicate significant differences at $\mathrm{P}<0.01$ for Fisher's LSD test after ANOVA. 


\section{Effect of different host plants}

Mean prey searching time of EO for ABW larvae was significantly different between the host plants ( $d f=2 ; F=54.089 ; P=0.000$ ) (Fig. 7). When ABW larvae were offered on cotton leaves EO was able to locate them more easily than on cabbage leaves ( $24.2 \pm 1.91$ and $36.75 \pm 3.961$ minutes); however, in Petri dishes EO was able to catch them within 1-3 seconds.

Mean prey consumption time of EO for ABW larvae was not different between the ABW larvae offered on cotton plants and cabbage plants but in the Petri dishes consumption time of EO for ABW larvae was about three times quicker than on the plants (df $=2 ; F=52.933 ; P=0.000)(F i g .8)$.

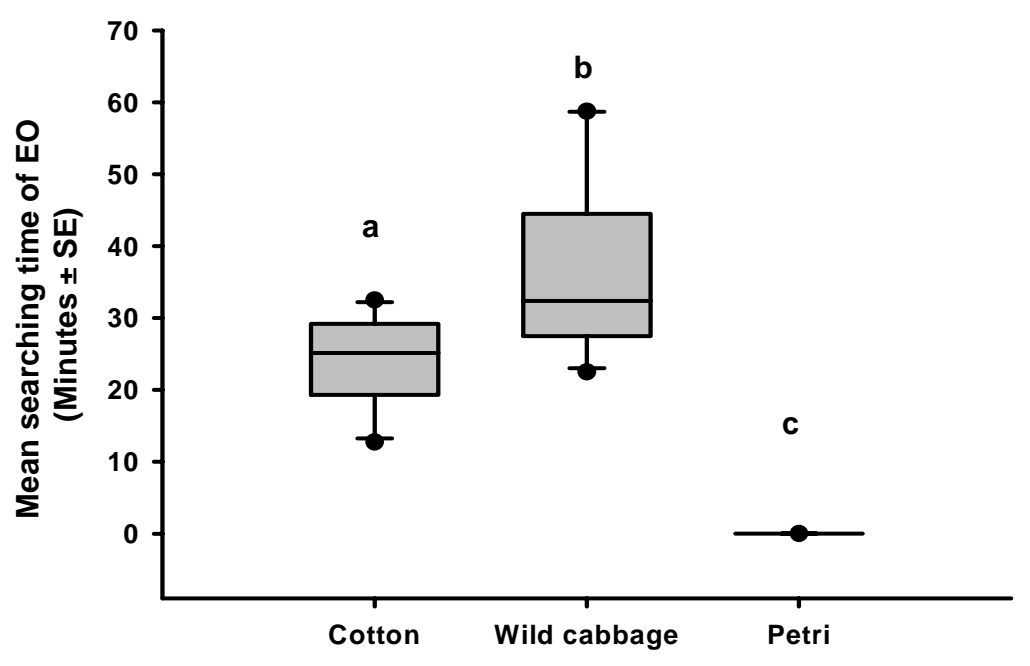

Figure 7: Mean searching time of EO when offered ABW larvae on the cotton plants, wild cabbage plants and in Petri dishes. Different letters indicate significant differences at $P<0.01$ for Fisher's LSD test after ANOVA. 


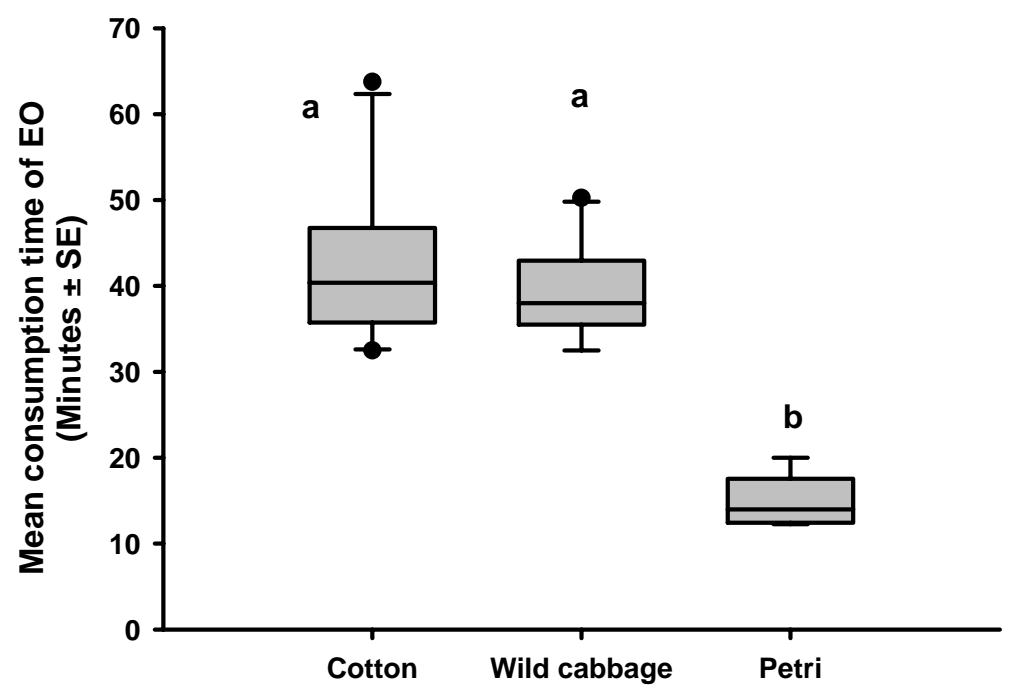

Figure 8: Mean consumption time of EO when offered ABW larvae on the cotton plants, wild cabbage plants and in Petri dishes. Different letters indicate significant differences at $P<0.01$ for Fisher's LSD test after ANOVA.

\section{Effect of different conditions}

Visiting time of EO on host plants differing in their status was significantly different (df $=2 ; F=115.64 ; P=0.000$ ) (Fig. 9). EO visits on control cotton and cabbage plants were distinctly shorter ( $5.8 \pm 1.618$ and $10.0 \pm 1.606$ minutes $)$ as compared to insect infested plants and visiting time of EO on ABW infested cotton plants was reduced by half than on DBM infested cabbage plants $(5.8 \pm 1.618$ and $10.0 \pm$ 1.606 minutes). 


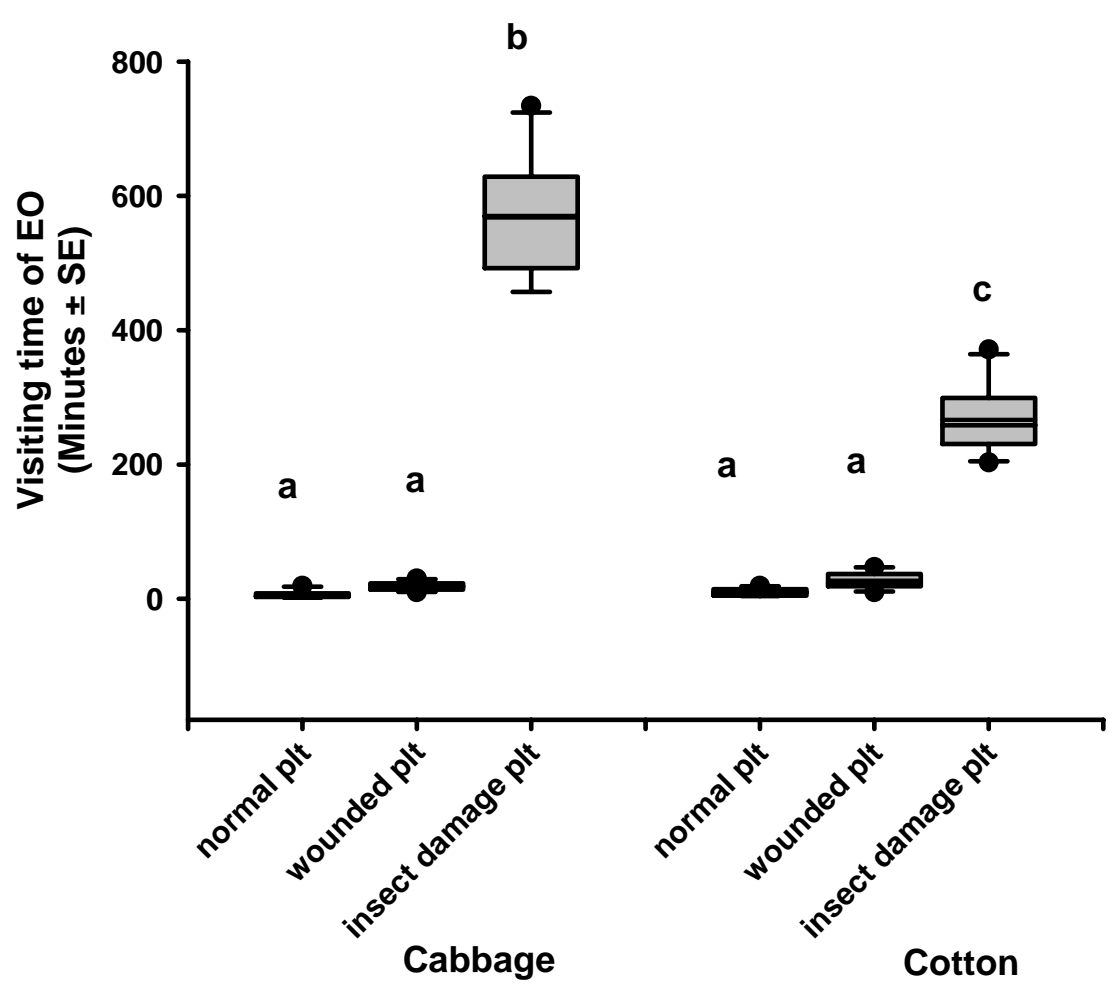

Figure 9: Visiting time of EO on different host plants (wild cabbage, cotton) and also on different conditions (control,, wounded and insect damage plants). Same letters indicate no significant differences at $P<0.01$ for Fisher's LSD test after ANOVA.

Observing of host choice behavior of Eocanthecona furcellata (EO) towards American bollworm (ABW) and Diamondback moth (DBM) larvae in Olfactometer

EO was attracted by both ABW and DBM larvae $43.75 \pm 5.58$ versus $30 \pm 5.16 \%$ respectively) and $25 \pm 4.87 \%$ of EO were did not leave the starting point (df $=2$; $F=3.471 ; P=0.033) ;(F i g .10)$. Searching time of EO was not significantly different on both prey items (3.33 \pm 0.78 minutes for DBM and $3.12 \pm 0.47$ minutes for $A B W$; df $=1 ; F=0.06 ; P=0.807 ;$ Fig.11). 


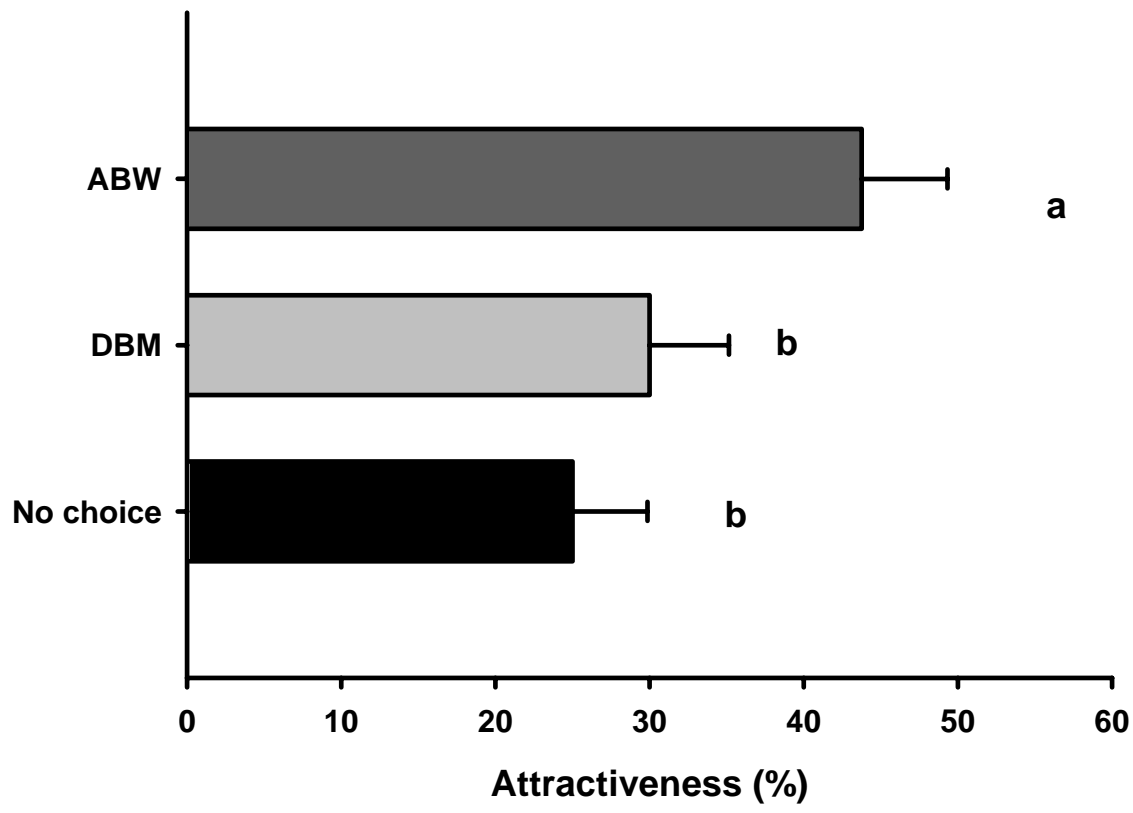

Figure 10: Responses of EO to odours of ABW and DBM larvae. Different letters indicate significant differences at $\mathrm{P}<0.05$ with Fisher's LSD test after ANOVA.

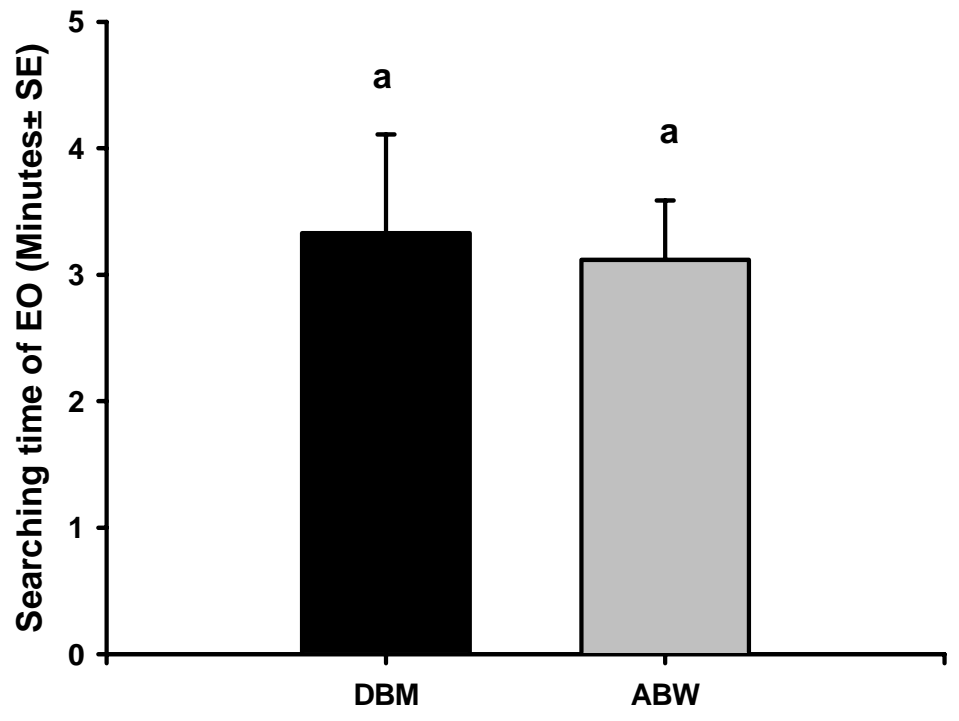

Figure 11: Searching time of EO to odours of ABW and DBM larvae. Different letters indicate significant differences at $P<0.01$ with Fisher's LSD test after ANOVA. 


\section{DISCUSSION}

This study demonstrates that prey species may influence the searching behavior of a predator bug. EO was not able to easily find DBM larvae because after placing the larva of DBM on the upper surface of each leaf, all larvae moved towards the lower surface of the leaf and started to feed there. On the other hand the green colour of DBM larvae may camouflage them given the colour of the leaves. However, we never observed dropping off the leaf when a predator approached near the DBM larva. On the other hand EO waited a maximum of 15 minutes at that place until DBM climbed up again and then preyed on the larva. In contrast, only 2-3 minutes waiting time was needed for catching brown coloured ABW larvae that fed on the upper surface of the cabbage plant leaves. Drop off behaviour of ABW larvae was recorded in many studies (Awan 1985; Johnson and Zalucki 2005; Terry et. al. 1989) but larvae never displayed this behaviour in our experiments. EO approaching behaviour was studied by Yasuda (1997, 1998a, b, 2000). He proved that EO used 2 different chemical cues: $n$-Pentadecane (C15) as a long-range attractant and $(E)$-phytol as a short distance attractant as a kairomone to locate larvae of several lepidopterans.

Our results als indicate that the searching behavior of EO significantly differed between host plants. Searching time of EO on cotton plants was lower than on cabbage plants, because EO walked slower on cotton leaves and spent more time on the upper part of the cotton plant but searching was more repeated on the whole plants as compared to cabbage plants. The influence of the host plants on the behaviour of predators was found in other studies as well (Coll et. al. 1997; Grosman et. al. 2005; Guershon and Gerling 2006; Yang 2000). Prey consumption time of predator EO for ABW larvae increased on cotton plants as compared to cabbage plants was probably influenced by the prey's host plants (Bergman and Tingey 1979). Prey searching time of EO was on average only 1-3 seconds in the Petri dishes but 24 minutes on cotton plants and 37 minutes on cabbage plants for each ABW larvae and prey consumption time of EO on the plants was about 3 times longer than in Petri dishes. These results may help to calculate the numbers of predator to be released in the field. 
Mechanically damaged plants were more attractive than control plants of both species but did not significantly differ from normal plants. EO was strongly attracted by insect infested plants and these results are supported by findings of Yasuda (1997) who showed that free phytol is produced by insect damaged plants attracting the predatory stink bug EO. These results are also consistent with Krips et. al. (2001), Takabayashi et. al. (1991) and Venzon et. al. (1999). They reported that insect induced plants were attracted for predators.

Prey selection of EO was studied in the Y-Olfactometer and the results indicate that EO was attracted more by ABW than by DBM larvae; however, searching time of EO was not significantly different between both larvae.

Results from our experiments indicate that the predatory bug $E$. furcellata seems to be a good predator to be included into existing biological control programs for the American bollworm on cotton plants. Howver, it may be useful to consider the surrounding vegetation for releasing EO as a biocontrol agent to control ABW in Myanmar.

\section{REFERENCE}

Ahmad M., A. P. Singh, S. Sharma, R. K. Mishra and M. J. Ahmad (1996) Potential estimation of the predatory bug Canthecona furcellata Wolff (Hemiptera: Pentatomidae) against popular defoliator Clostera cupreata (Lepidoptera: Notodontidae). Annals of Forestry 4: 133-138

Armes, N.J., D.R. Jadhav \& K.R. Desouza (1996) A survey of insecticides resistance in Helicoverpa armigera in the Indian subcontinent. Bulletin of Entomological Research 86: 499-514.

Awan M. S. (1985) Anti-predatory ploys of Heliothis punctigera (Lepidoptera: Noctuidae) caterpillars against the predator Oechalia schellenbergii (Hemiptera: Pentatomidae). Aust. J. Zool. 33: 885-890 
Bell P.D., P.G Fenemore (1990) Insecticide resistance in diamondback moth in New Zealand. Proceeding of the 43th New Zealand Plant Protection Conferences: 31-34

Bell, W.J. (1990) Searching behavior patterns in insects. Annu. Rev. Entomol. 35: 447-467

Bergman, J.M. and M.W. Tingey (1979) Aspects of interactions between plant genotypes and biological control. Bulletin of Entomological Society of America 25: 275-279

Chang, C-P (2002) Mass rearing and utilization of the predatory stink bug Eocanthecona furcellata. Formosan Entomologist 3: 175-181 (in Chinese with English abstract)

Chu, Y. (1975) Rearing density of Eocanthecona furcellata, with special consideration to its mass production (Asopinae: Pentatomidae). Rostria 24: 135-140 (in Japanese with English abstract)

Coll, M., L.A. Smith and R.L. Ridgway (1997) Effect of plants on the searching efficiency of a generalist predator: the importance of predator- prey spatial association. Entomol. Exp. Appl. 83:1-10

Commonwealth Institte of Entomology (1968) Distribution maps of pests, Ser. A, No. 15, H. armigera (Revised). London: Commonw: Inst. Entomol.

Endersby, N., P. Ridland (1994) Insecticide resistance in Victorian populations of diamondback moth, Plutella xylostella (L.). Australian Entomological Society Conference, Abstract, 31.

Fitt, G.P. (1989) The ecology of Heliothis species in relation to agroecosystems. Annual Review of Entomology 7: 685-688.

Gillham, F.E.M. (1980) Introduction to cotton insect pest control in Burma. Seed development project report no. 22. Ministry of Agriculture and Forests, Rangoon, Burma. 77pp. 
Grosman, A.H., M. van Breemen, A. Holtz, A. Pallini, A. M. Rugama, H. Pengel, M. Venzon, J. C. Zanuncio, M. W. Sabelis, A. Janssen (2005) Searching behaviour of an omnivorous predatoe for novel and native host plants of its hervivores: a study on the arthropod colonization of eucalyptus in Brazil. Entomol. Exp. Appl. 116:135-142

Guershon, M. and D. Gerling (2006) Effect of plant and prey characteristics on the predatory behavior of Delphastus catalinae. Entomol. Exp. Appl.121:15-21

Hill, Dennis S. (1983) Agricultural Insect Pests of the Tropics and their Control, $2^{\text {nd }}$ edition, Cambridge University press.

Jakhmola, S. S. (1983) Natural enemies of Til leafroller and capsuleborer, Antigastra catalaunalis (Dup.). Bull. Entomol. 24 (2): 147-148.

Johnson, M-L., and M. P. Zalucki (2005) Foraging behaviour of Heliothis armigerafist instar larvae on crop plants of different developmental stages. J. Appl. Entomol. 129(5): 239-245

Khin Thein Nyunt (2001) Impact of planting dates on the population of cotton pests and natural enemies in Myanmar. M.Sc.agr. thesis at Georg-AugustUniversity, Goettingen, Germany. 99 p.

Khin Thein Nyunt and S. Vidal (2006) Potential for biocontrol of the Diamondback Moth in Myanmar by using a predatory bug. Poster presented at Deutscher Tropentag, 11-13 October 2006, Bonn, Germany. University press, Bonn. Book of Abstracts $613 \mathrm{p}$.

Khin Thein Nyunt and S. Vidal (2007a) Predation potential of the pentatomid stink bug Eocanthecona furcellata at different temperature regimes. Poster presented at Entomologentagung, 26.2-1.3.2007, Innsbruck, Austria. Universitätverlag Wagner, Innsbruck. Book of Abstracts 290 p.

Khin Thein Nyunt and S. Vidal (2007b) Predator efficiency of Eocanthecona furcellata on Helicoverpa armigera larvae reared on different host plants. 
Poster presented at Deutscher Tropentag, 9-12 October 2007, Witzenhausen, Germany. Cuvillier Verlag, Goettingen. Book of Abstracts $551 \mathrm{p}$.

Krips, O. E., Willems, P. E. L., Gols, R., Posthumus, M. A., Gort, G. \& Dicke, M. (2001). Comparison of cultivars of ornamental crop Gerbera jamesonii on production of spider mite-induced volatiles, and their attractiveness to the predator Phytoseiulus persimilis. Journal of Chemical Ecology 27: 13551372.

MCSE (1999) Main Cotton Pest in Myanmar and their Control (in Myanmar), Myanma Cotton and Sericulture Enterprise, pp 40

Morris, H. and D. F. Waterhouse (2001) The distribution and important of arthropod pest and weeds of agriculture in Myanmar. ACIAR Monograph No. 67,73 pp.

$\mathrm{Nu} \mathrm{Nu}$ Yi and Win Kyi (2000) Biological control of cotton bollworm and chickpea pod borer, Helicoverpa armigera y using predator Eocanthecona furcellata and parasitoid Campoletis chlorideae. In proceeding of the annual research conference, April 3-5, 2000, Yangon, Myanmar. 58-74 pp.

Prasad, D., K. M. Singh, R. N. Singh, and D. N. Mehto (1983) A new predator of new pest of jasmine in Delhi. Bull. Entomol. 24: 140-141.

Reed, W. and C. S. Pawar, (1982) Heliothis: a global problem. Proc. Int. Workshop Heliothis Management, Patancheru, India ICRISAT. 418 pp.

Saxena, J.D., S. Rai, K.M. Srivastava \& S.R. Sinha 1989. Resistance in the field population of the diamondback moth to some commonly used synthetic pyrethroids. Indian J. Entomol. 51: 265-268

SPSS Inc., (2004). Systat 11 for Windows; SPSS Inc., Chicago, USA.

Sun C-N 1992. Insecticide resistance in diamondback moth. In: Talekar NS ed. Diamondback moth and other crucifera pests. Proceedings of the 2nd 
International Workshop, Taiwan, December 1990, AVRDC publication. 419$426 \mathrm{pp}$.

Tabashnik B. E., N. L. Cushing, M. W. Johnson 1987. Diamondback moth (Lepidoptera: Plutellidae) resistance to insecticides in Hawaii: Intra-island variation and cross-resistance. Journal of Economic Entomology 80, 10911099.

Takabayashi, J., Dicke, M. \& Posthumus, M. A. (1991). Variation in composition of predator-attracting allelochemicals emitted by herbivore-infested plants: relative influence of plant and herbivore. Chemoecology 2: 1-6.

Terry, I., J. R. Bradley, and J. W. Van Duyn (1989) Establishment of early instar Heliothis Zea on soybeans. Entomol. Exp. Appl. 51: 233-240

Venzon, M., Janssen, A. \& Sabelis, M. W. (1999). Attraction of a generalist predator towards herbivore-infested plants. Entomol. Exp. Appl. 93: 305314.

Yang, L. H. (2000) Effect of body size and plant structure on the movement ability of a predatous stinkbug Podisus maculiventris (Hemiptera: Pentatomidae). Oecologia 125: 85-90

Yasuda, T. and S. Wakamura (1996) Behavioral response in prey location of the predatory stink bug, Eocanthecona furcellata, to chemical cues in the larvae of Spodoptera litura. Entomol. Exp. Appl. 81:91-96

Yasuda, T. (1997) Chemical cues from the Spodoptera litura larvae elicit preylocating behavior of generalist predatory stink bug Eocanthecona furcellata. Entomol. Exp.Appl.,82: 349-354

Yasuda, T. (1998a) Effects of (E)- Phytol of several lepidopteran species in preylocating behavior of generalist predatory stink bug Eocanthecona furcellata (Heteroptera: Pentatomidae). Entomol.Sci. 1:159-164 
Yasuda, T. (1998b) Role of chlorophyll content of prey diets in prey- locating behavior of generalist predatory stink bug Eocanthecona furcellata. Entomol. Exp.Appl.,86: 119-124

Yasuda, T. (2000) Role of semiochemicals in prey- locating behavior of generalist predatory stink bug Eocanthecona furcellata (Wolff) (Hemiptera: Pentatomidae) Jpn. Agric. Res.Q.34:15-20

Yasui, H. (2001) Sequestration of host plant- derived compounds by geometrid moth, Milionia basalis, toxic to a predatory stink bug Eocanthecona furcellata J. of Che. Ecology 27(7): 1345-1353

Zalucki, M. P., G. Daglish, S. Firempong, and P. Twine (1986) The biology and ecology of Heliothis armigera (Hübner) and $H$. punctigera Wallengern (Lepidoptera: Noctuidae) in Australia: What do we know? Aust. J. Zool. 34: 779- 814 


\section{GENERAL DISCUSSION}

American bollworm is the most severe pest of economically important crops like cotton, chickpea, pigeonpea, and maize in Myanmar. Even though chemical insecticides were widely applied to control this pest, yield loss on seed cotton was not uncommon. Yield reduction may be a high as 90 percent in some cases (Myat Htwe and Mya Maung, 1992). Biological control is recognized as one of the best alternatives to the use of chemical insecticides for controlling insect pests. Pest control with natural enemies has been increasing due to environmental, economical, social and ecological problems with insecticides and Heteropteran predators are important biological control agents on Lepidopteran pests. The predatory pentatomid bug Eocanthecona furcellata (Wolff) (EO) is regarded a potential biological control agent against lepidopteran pests in Southeast Asia.

I am interesting to get the answer of this question. Can predatory bug E. furcellata be a potential biocontrol agent to control American bollworm?

The main aim of my study is to observe the ecology and biology of Eocanthecona furcellata by:

1. Prey preferences and predation efficacy of Eocanthecona furcellata

2. Prey consumption and fitness of Eocanthecona furcellata Wolff (Hemiptera: Pentatomidae) on Diamondback moth larvae at different temperature regimes and prey density

3. Prey searching and feeding behavior of Eocanthecona furcellata Wolff (Hemiptera: Pentatomidae) on different preys (American bollworm and Diamondback moth), different host plants (cotton and wild cabbage) and different conditions (normal plant, wounded plant, and insect infected plant) 


\section{Prey preferences and predation efficacy of Eocanthecona furcellata}

The significant differences were found in larval weight when the larvae of $H$. armigera reared on different host plants. The smallest larvae got from tomato plant and the biggest from artificial diet. Similar result was found by Lui (2004) that body weight of young last instar ABW larvae ranged from $176.7 \mathrm{mg}$ on cotton to 132.5 mg on cherry tomato. Sharmad (2005) also found that larvae of $H$. armigera weighed $<50 \mathrm{mg}$ when reared on Cicer pinnatifidum because the wild relatives of chickpea showing high levels of antibiosis to $H$. armigera. Moreover, Subramanian (2006) proved that the effect of host plant influenced on the genetic variability of $H$. armigera population.

Predation efficacy of EO was tested with American Bollworm from four different host plants (Cabbage, Cotton, Chickpea and Tomato). Majority of EO approached towards cotton plants eating ABW larvae. Predatory EO response to $(E)$ - phytol, which is produced by larvae from chlorophyll in food plant and EO more prefer to feed on the larvae with chlorophyll-rich diet than on chlorophyll-poor diet (Yasuda, 1997, 1998a, 1998b), My results correspond to their finding that larvae reared with artificial diet, which basically made from bean flour, were inadequately attractive to EO in my experiment. Henaut (2000) found that the predatory bug Orius majusculus (Reuter) adults that had no experience of aphid predation as nymphs did not prey on pea aphids in the experimental arena. Therefore, prey nutrient and the standard diet used for rearing EO may affect the efficiency of the predator as an agent of biological control.

When ABW larvae and their faeces were wrapped with Para film ' $M$ ', the prey selecting efficacy was significantly reduced up to 20-40\%. Most of the predators were walking around in the plastic box and when they touched the prey with the tip of their antennae, they extended the rostrum and then approached and sucked the body fluids of ABW larvae. They didn't select all larvae faeces from different host plant and predation on the larvae reared on cotton plants reduced about half percent compare with the first experiment. Yasuda (1997) described that about 
$90 \%$ of the $(E)$ - phytol can detect in the faeces of S. litura. EO fed the faeces of ABW in the first experiment but after covering with Para film ' $M$ ', none of EO interested in faeces. Para film ' $M$ ' seen to prevent the visual and olfactory cue from prey larvae and their faeces but predatory bug can detect the prey by vibration. Vibrations produced by prey as they chew on leaves may be an important cue used by the predatory stinkbug Podisus maculiventris (Say) to locate the prey (Pfannenstiel, 1995).

\section{Prey consumption and fitness of Eocanthecona furcellata Wolff (Hemiptera: Pentatomidae) on Diamondback moth larvae at different temperature regimes and prey density}

The result of the experiment showed that EO was successfully feed and complete its development at the temperatures $\left(25^{\circ} \mathrm{C}, 30^{\circ} \mathrm{C}\right.$, and $\left.35^{\circ} \mathrm{C}\right)$ with regard to all prey density tests. The average developmental period was significantly shorter at higher temperature $35^{\circ} \mathrm{C}$. These results correspond to Chang (2001) and also agreed with the results of some previous studies on Podisus maculiventris (Legaspi, 2004; Mohaghegh et. al., 2001); on Podisus nigrispinus (Medeiros et. al., 2003); on Rhyzobius lophanthae (Stathas, 2000); and on Scymnus levaiillanti (Uygun and Atlihan, 2000). Nymph developmental times decreased with rising the prey densities up to 10 DBM larvae. The interaction of temperature and prey densities also affect on the longevity of predator EO. The shortest Nymph developmental time (egg to adult) was found double at $35^{\circ} \mathrm{C}$ when daily offered 10 DBM larvae and the longest was at $25^{\circ} \mathrm{C}$ fed with only 1 DBM larva. Adult are able to survive longer when temperatures are lower. The total developmental time of EO (egg to mortality of adults) takes two times longer at $25^{\circ} \mathrm{C}$ than at $35^{\circ} \mathrm{C}$. If EO has enough prey, they may have up to 11 generations per year. This is a promising result for biological control in hot countries like Myanmar.

Successful biological control of a pest is based on the face that the natural enemy kills a sufficient number of a prey to keep its density at low level. Daily prey consumption of EO on DBM larvae increased gradually with increasing prey density. The highest amount of daily prey consumption per $5^{\text {th }}$ instar Nymph of EO 
was found at $30^{\circ} \mathrm{C}$ when we offered 10 DBM larvae. Similar result was found by Saleh et. al.(2003) for prey consumption by Dicyphus tamaninii Wagner (Het., Miridae) with Aphis gossypii Glover at $30^{\circ} \mathrm{C}$. Decreasing of prey consuming was found at higher temperature $35^{\circ} \mathrm{C}$ and EO can consume a minimum of DBM larvae at $35^{\circ} \mathrm{C}$ to maximum DBM larvae (about 10 time) at $25^{\circ} \mathrm{C}$. But prey consumption was high at $23^{\circ} \mathrm{C}$ for predatory stink bug $P$. bidens and $P$. maculiventris (Mahdian et. al.,2006) Functional responses describe the trend in which the number of prey consumed per predator changes with changes in prey density (Solomon, 1949).

Predation rates of EO on DBM larvae increased with nymph instars and the highest amount of predation rate was recorded from $5^{\text {th }}$ Nymph of EO at all tested temperatures. The most favorable predation rate were found at $30^{\circ} \mathrm{C}$ on $4^{\text {th }}$ and $5^{\text {th }}$ instars EO nymph and daily prey consumption of $4^{\text {th }} \& 5^{\text {th }}$ instars of EO nymphs is also high enough for mass releasing purposes in biological control strategies. High predation rates of $P$. bidens was found at a wide range of temperatures (Mahdian et. al.,2006). Therefore it suggests that the species may be a valuable asset for the biological control of Diamondback moth, provided that obstacles to its mass production can be overcome.

Statistical analyses revealed that temperature and prey density as well as their interaction were significantly affected on adult weight. The gender also significantly affect on adult weight at three tested temperature, with the female being heavier and bigger than males.

The result of the experiments conducted on the effect of extreme temperatures on the development of EO showed that, the predator bug was able to develop $50 \%$ and $90 \%$ from $2^{\text {nd }}$ instar to adult stage at the constant temperatures $20^{\circ} \mathrm{C}$ and $37^{\circ} \mathrm{C}$. EO was able to survive at these two constant temperatures; however EO was unable to lay the eggs at $20^{\circ} \mathrm{C}$ and even though they could lay the eggs at $37^{\circ} \mathrm{C}$, no eggs was able to hatch to nymphs. The $2^{\text {nd }}$ instars EO survived for 12.6 $\left( \pm 0.40\right.$ ) days at $15^{\circ} \mathrm{C}$ and $\mathrm{EO}$ did only survive for one day at $40^{\circ} \mathrm{C}$ and all EO died during moulting the stage of the $2^{\text {nd }}$ instars to the $3^{\text {rd }}$ instar nymphs at both 
temperatures. Therefore no viable offspring were recorded in four tested extreme temperatures. Low temperature threshold for EO is $15^{\circ} \mathrm{C}$ and high temperature threshold is $40^{\circ} \mathrm{C}$.

The prey consumption by EO during its development and adulthood, by feeding on DBM as prey, was considerably temperature dependent. $2^{\text {nd }}$ instar EO nymph consumed about $1 / 3$ larvae per day at $15^{\circ} \mathrm{C}$ and $40^{\circ} \mathrm{C}$ while 2 and 6 larvae at $20^{\circ}$ and $37^{\circ} \mathrm{C}$. The daily prey consumption by EO at $37^{\circ} \mathrm{C}$ increased gradually with EO instars, where it was $5.90( \pm 0.53)$ DBM larvae for $2^{\text {nd }}$ instar EO nymph and reached up to 23.09 ( \pm 0.61) DBM larvae for adult EO but adult longevity last only $12.67( \pm 0.58)$ days even though adult can survive $69.2( \pm 1.24)$ days at $20^{\circ} \mathrm{C}$. Until their entire lifespan, one EO was able to consume up to 260.00 ( \pm 16.56$)$ larvae at $20^{\circ} \mathrm{C}$ and $388.89( \pm 8.20)$ larvae at $37^{\circ} \mathrm{C}$. Adult weight of EO was significantly affected by temperature and gender; female weight of EO was heavier than male weight at $20^{\circ} \mathrm{C}$ and $37^{\circ} \mathrm{C}$. Effects of extreme temperatures can lead to failure of an IPM strategy that may be quite effective in a narrow temperature range (Horn, 1998). Biological control agents, especially arthropod natural enemies, often exhibit temperature optima different from those of their prey, and may become ineffective at higher or lower temperatures.

As a result EO seems to be adapted to climatic conditions prevailing in the tropical regions. Given these preferences EO may be used for biological control purposes only in areas with mean temperatures of above $25^{\circ} \mathrm{C}$.

\section{Prey searching and feeding behavior of Eocanthecona furcellata Wolff (Hemiptera: Pentatomidae on different prey items, host plant species and plant status}

This study demonstrates the prey species can influence the searching behavior of predator bug. EO could not find easily for DBM larvae because of their feeding habit on the lower surface of the leaf. On the other hand green colour DBM larvae could confuse with leaves colour and dropping off behavior was found when predator approached near the DBM larva but EO waited maximum 15 minutes 
from that place until DBM climbing up and then caught the larva. In contrast, only 2-3 minutes waiting time was needed for catching brown colour ABW larvae that fed on the upper surface of the wild cabbage. Drop off behaviour of ABW larvae was recorded in many studies (Awan 1985; Johnson and Zalucki 2005; Johnson et. al. 2007; Terry et. al. 1989) but drop off behaviour of ABW larvae was not found for in this experiment. EO approaching was studied by Yasuda in 1997, 1998 and 2000, and he prove that EO used 2 different chemical cue ( $n$-Pentadecane (C15) as a long-range attractant for bug and (E)-phytol as a short distance) as kairomones to locate larvae of several lepidopterans.

The results indicated that searching behavior of predator EO was a significant difference between host plants. Searching time of predator EO on cotton plants was lower than on wild cabbage plants, even EO walked slower on cotton leaves and spent more time on the upper part of the cotton plant but more repeated searching on the whole plants was found on wild cabbage. Many study also proved that predator behavior was influenced by the host plants (Coll et. al. 1997; Guershon and Gerling 2006; Grosman et. al. 2005; Yang 2000). Prey consumption time of predator EO for ABW larvae was longer on cotton plants than wild cabbage plants and it may be influenced by the prey's host plants (Bergman and Tingey 1979; Carter et. al. 1984; Kareiva and Sahakian 1990; Rapusas et. al. 1996). Prey searching time of predator EO was only average 1-3 seconds in the Petri dishes but 24 minutes in cotton plant and 37 minutes in wild cabbage plants for each ABW larvae and prey consumption time of EO on the plants was about 3 times longer than in Petri dished. This result could help to predict the releasing population of predator in the field.

Mechanically damaged plants were more attractive than normal plants of both species but not statistically different between normal and damaged plants. Predator bug EO was strongly attracted by insect infested plants and these results are support to the finding of Yasuda (1997) that free phytol produced by insect damaged plants attracted the predatory stink bug E. furcellata. These results also consistent with Krips et. al. (2001), Takabayashi et. al. (1991) and Venzon et. al. (1999). They report that insect induced plants were attracted by predator. 
Prey selection of EO was studied in the Olfactometer and the results indicate that EO was more attractive by ABW than DBM larvae and the searching time of EO was not significantly different on both larvae. It may be helpful for consideration of the surrounding vegetation for releasing EO as biocontrol agent to control ABW in Myanmar.

Results from these experiments indicated that the predatory bug E. furcellata seems to be a good predator to incorporate into an existing biological control program for American bollworm on cotton plant. 


\section{CONCLUSION}

1. The highest numbers of $H$. armigera eggs was recorded on chickpea plants, followed by tomato, cotton and cabbage plants.

2. The best performance of $H$. armigera larvae was recorded on artificial diet followed by wild cabbage, cotton, chickpea and tomato plants.

3. American Bollworm reared on cotton plant was the optimal prey for predatory EO compare with ABW reared on chickpea plant, wild cabbage plant and tomato plant. EO selected ABW larvae even larvae were wrapped with Para film 'M'.

4. The optimal temperature for rearing and releasing for predatory bug EO was $30^{\circ} \mathrm{C}$ and the highest predation rate and reliable developmental time of EO was found at this temperature.

5. No viable offspring were recorded in four tested extreme temperatures; $15^{\circ} \mathrm{C}$, $20^{\circ} \mathrm{C}, 37^{\circ} \mathrm{C}$, and $40^{\circ} \mathrm{C}$.

6. Prey searching and consumption behaviour of predatory bug EO on ABW larvae was higher than DBM larvae in green house condition

7. Predatory bug EO can easily find their prey on cotton plant than wild cabbage plant.

8. Predator bug EO was strongly attracted by insect infested plants compare to normal plants and mechanically damaged plants.

9. The result of Olfactometer proved that EO was more attractive by ABW and the searching time of EO was not significantly different on both larvae of ABW and DBM.

Based on these finding, predatory stink bug Eocanthecona furcellata can be used to release the predatory bug Eocanthecona furcellata in cotton fields as a biocontrol agent for controlling Helicoverpa armigera in Myanmar. 


\section{REFERENCES}

Ahmad M., A. P. Singh, S. Sharma, R. K. Mishra and M. J. Ahmad (1996) Potential estimation of the predatory bug Canthecona furcellata Wolff (Hemiptera: Pentatomidae) against popular defoliator Clostera cupreata (Lepidoptera: Notodontidae). Annals of Forestry 4: 133-138

Armes, N.J., D.R. Jadhav \& K.R. Desouza (1996) A survey of insecticides resistance in Helicoverpa armigera in the Indian subcontinent. Bulletin of Entomological Research 86: 499-514.

Awan M. S. (1985) Anti-predatory ploys of Heliothis punctigera (Lepidoptera: Noctuidae) caterpillars against the predator Oechalia schellenbergii (Hemiptera: Pentatomidae). Aust. J. Zool. 33: 885-890

Bell P.D., P.G Fenemore (1990) Insecticide resistance in diamondback moth in New Zealand. Proceeding of the 43th New Zealand Plant Protection Conferences: 31-34

Bergman, J.M. and M.W. Tingey (1979) Aspects of interactions between plant genotypes and biological control. Bulletin of Entomological Society of America 25: 275-279

Biever, K. D. and R. L. Chauvin (1992) Suppression of the Colorado potato beetle (Coleoptera: Chrysomelidae) with augmentative releases of predaceous stinkbugs (Hemiptera: Pentatomidae). J. Econ. Entomol., 85, 720-726.

Capinera JL. (2001) Handbook of Vegetable Pests. Academic Press, San Diego. $729 \mathrm{pp}$.

Chang, C-P (2001) Predatory capacity of the predatory stink bug Eocanthecona furcellata (Wolff) (Hemiptera: Pentatomidae) on various prey. Formosan Entomologist 21: 257-267 (in Chinese with English abstract) 
Chang, C-P (2002) Mass rearing and utilization of the predatory stink bug Eocanthecona furcellata. Formosan Entomologist 3: 175-181 (in Chinese with English abstract)

Chu, Y. (1975) Rearing density of Eocanthecona furcellata, with special consideration to its mass production (Asopinae: Pentatomidae). Rostria 24: 135-140 (in Japanese with English abstract)

Coll, M., L.A. Smith and R.L. Ridgway (1997) Effect of plants on the searching efficiency of a generalist predator: the importance of predator- prey spatial association. Entomol. Exp. Appl. 83:1-10

Commonwealth Institte of Entomology (1968) Distribution maps of pests, Ser. A, No. 15, H. armigera (Revised). London: Commonw: Inst. Entomol.

Cotter, S.C. and O.R. Edwards (2006) Quantitative genetics of preference and performance on chickpeas in the noctuid moth, Helicoverpa armigera. Heredity 96: 396-402

Courtney S. P. \& T.T. Kibota (1990) Mother doesn't know best: selection of host by ovipositing insect. In: Insect-Plants Interactions (ed. E.A. Bernays), pp. 161188. CRC press, Boca Raton, USA.

De Clercq, P. and D. Degheele (1990) Effects of temperature and relative humidity on the reproduction of the predatory bug Podisus sagitta (Fab.) (Heteroptera: Pentatomidae) Mededelingen Faculteit Landbouwwetenschappen Rijksuniversiteit Gent 55: 439-443

De Clercq, P. and D. Degheele (1992) Development and survival of Podisus maculiventris (Say) and Podisus sagitta (Fab.) (Heteroptera: Pentatomidae) at various constant temperatures. Can. Entomol., 124: 125-133

De Clercq, P. \& D. Degheele (1994) Laboratory measurements of predation by Podisus maculiventris and $P$. sagitta (Hemiptera: Pentatomidae) on beet 
armyworm (Lepidoptera: Noctuidae) Journal of Economic Entomology 87: 76-83

De Clercq, P., K. Wyckhuys, H.N. De Oliveira and J. Klapwijk (2002) Predation by Podisus maculiventris on different life stages o $f$ Nezara viridula. Florida Entomologist 85(1): 197-202

De Clercq, P., I. Peeters, G. Vergauwe and O. Thas (2003) Interaction between Podisus maculiventris and Harmonia axyridis, two predators used in augmentative biological control in greenhouse crops. BioControl 48: 39-550

Endersby, N., and P. Ridland (1994) Insecticide resistance in Victorian populations of diamondback moth, Plutella xylostella (L.). Australian Entomological Society Conference, Abstract, 31.

Fitt, G.P. (1989) The ecology of Heliothis species in relation to agroecosystems. Ann. Rev. Entomol. 7: 685-688.

Fitt, G.P. (1991) Host selection in Heliothinae. In:Reprodctive behaviour of insects: Individuals and populations (eds WJ Bailey and J Ridsdill-Smith). pp 127201. Chapman and Hall, Landon, UK.

Fitt, G.P. and G.S. Boyan (1991) Method for studying behavior. In: Helicoverpa research methods and prospects (ed. M.P. Zalucki). pp 122-150. SpringerVerlag, New York, USA.

Frisbie, R. E. (1983): Guidelines for Integrated control of cotton pest. FAO. Rome, pp187

Gillham, F.E.M. (1980) Introduction to cotton insect pest control in Burma. Seed development project report no. 22. Ministry of Agriculture and Forests, Rangoon, Burma. 77pp.

Grosman, A.H., M. van Breemen, A. Holtz, A. Pallini, A. M. Rugama, H. Pengel, M. Venzon, J. C. Zanuncio, M. W. Sabelis, A. Janssen (2005) Searching 
behaviour of an omnivorous predatoe for novel and native host plants of its hervivores: a study on the arthropod colonization of eucalyptus in Brazil. Entomol. Exp. Appl 116:135-142

Guershon, M. and D. Gerling (2006) Effect of plant and prey characteristics on the predatory behavior of Delphastus catalinae. Entomol. Exp. Appl 121:15-21

Harcourt, D. G. (1957) Biology of the Diamondback Moth, Plutella maculipennis (Curt.) (Lepidoptera: Plutellidae), in Eastern Ontario. II. Life-History, Behavior, and Host Relationships. Can. Entomol. 89: 554-564.

Hassell, M.P. (1985) Insect natural enemies as regulation factors. J. Anim. Ecol. 54: $323-334$

Henaut, Y., C. Alauzet, A. Ferran, T. Citation Williams (2000) Effect of nymphal diet on adult predation behavior in Orius majusculus (Heteroptera: Anthocoridae). J.Econ.Entomol. Apr; 93(2): 252-5

Hill, Dennis S. (1983) Agricultural Insect Pests of the Tropics and their Control, $2^{\text {nd }}$ edition, Cambridge University press.

Ho, H.-Y., R. Kou, and H.-K. Tseng (2003) Semiochemicals from the predatory stink bug Eocanthecona furcellta (Wolff): components of metathoracic gland, dorsal abdominal gland, and sternal gland secretions, Journal of Chemical Ecology 29(9): 2101-2114

Horn, D. J.(1998) Temperature Synergism in Integrated Pest Management, in Temperature sensitivity in insects and application in integrated pest management edited by Guy J. Hallman and David L. Denlinger. Westview Press, 311p.

Hough-Goldstein, J. and D. McPherson (1996) Comparison of Perillus bioculatus and Podisus maculiventris (Hemiptera: Pentatomidae) as potential control agents of the Colorado potato beetle (Coleoptera: Chrysomelidae). J. Econ. Entomol. 89: 1116-1123. 
Jakhmola, S. S. (1983) Natural enemies of Til leafroller and capsuleborer, Antigastra catalaunalis (Dup.). Bull. Entomol. 24 (2): 147-148.

Jallow, M.F.A., M.P. Zalucki and G.P. Fitt (1999) Role of chemical cues from cotton in mediating host selection and oviposition behavior in Helicoverpa armigera (Hübner) (Lepidoptera: Noctuidae). Australian J. of Entomol. 38:359-366

Jallow, M.F.A., M. Matsumura and Y. Suzuki (2001) Ovipostion preference and reproductive performance of Japanese Helicoverpa armigera (Hübner) (Lepidoptera: Noctuidae). Appl. Entomol.Zool. 36 (4): 419-426

Jallow, M.F.A. and M.P. Zalucki (2003) Relation between ovipostion preference and offspring performance in Australian Helicoverpa armigera (Hübner) (Lepidoptera: Noctuidae). Australian J. of Entomol. 42: 343-348

Johnson, M-L., and M. P. Zalucki (2005) Foraging behaviour of Heliothis armigerafist instar larvae on crop plants of different developmental stages. J. Appl. Entomol. 129(5): 239-245

Johnson, M-L., S. Armitage, B. C. G. Scholz, D. J. Merritt, B. W. Cribb and M. P. Zalucki (2005) Foraging behaviour of Heliothis armigera first instar larvae on crop plants of different developmental stages. J. Insect Behav. 129(5): 239245

Kaushik. U.K., V.S. Rathore and N.K. Sood (1969) Incidence of bollworms and losses caused to cotton in Madhya Pradesh. Indian Journal of Entomology 31(2): 175-177.

Khin Thein Nyunt (2001) Impact of planting dates on the population of cotton pests and natural enemies in Myanmar. M.Sc.agr. thesis at Georg-AugustUniversity, Goettingen, Germany. 99 p.

Khin Thein Nyunt and S. Vidal (2006) Potential for biocontrol of the Diamondback Moth in Myanmar by using a predatory bug. Poster presented at Deutscher 
Tropentag, 11-13 October 2006, Bonn, Germany. University press, Bonn. Book of Abstracts $613 \mathrm{p}$.

Khin Thein Nyunt and S. Vidal (2007a) Predation potential of the pentatomid stink bug Eocanthecona furcellata at different temperature regimes. Poster presented at Entomologentagung, 26.2-1.3.2007, Innsbruck, Austria. Universitätverlag Wagner, Innsbruck. Book of Abstracts $290 \mathrm{p}$.

Khin Thein Nyunt and S. Vidal (2007b) Predator efficiency of Eocanthecona furcellata on Helicoverpa armigera larvae reared on different host plants. Poster presented at Deutscher Tropentag, 9-12 October 2007, Witzenhausen, Germany. Cuvillier Verlag, Goettingen. Book of Abstracts $551 \mathrm{p}$.

King E.G., J.E. Powell, and J.W Smith (1982) Prospects for utilization of parasites and predators for management of Heliothis spp. In proceedings of the international workshop on Heliothis management (W. Reed and Kumble eds.). ICRISAT; Patancheru, A. P., India. 103-122 pp

King A.B.S. (1994) Heliothis/Helicoverpa (Lepidoptera: Noctuidae). In Insect Pests of Cotton, Mathews G.A. and Turnstall J.P. (eds.). CAB International. Wallingford, U.K. 39-106 pp.

Krips, O. E., Willems, P. E. L., Gols, R., Posthumus, M. A., Gort, G. \& Dicke, M. (2001). Comparison of cultivars of ornamental crop Gerbera jamesonii on production of spider mite-induced volatiles, and their attractiveness to the predator Phytoseiulus persimilis. Journal of Chemical Ecology 27: 13551372.

Legaspi, J. C. (2004) Life history of Podisus maculiventris (Heteroptera: Pentatomidae) adult females under different constant temperatures, Environ. Entomol. 33 (5): 1200-1206 
Lemos, W. P., F. S. Ramalho, J. E. Serrão, and J. C. Zanuncio (2003) Effects of diet on development of Podisus nigrispinus (Dallas) (Het., Pentatomidae), a predator of the cotton leafworm. J. Appl. Ent. 127: 389-395.

Lingren, P.D., R.L. Ridgway, and S.L. Jones (1968) Consumption by several common arthropod predators of eggs and larvae of two Heliothis species that attack cotton. Ann. Entomol. Soci. America 61: 613-618

Liu, Z., Dianmo Li, Peiyu Gong, and Kunjun Wu (2004) Life Table Studies of the Cotton Bollworm, Helicoverpa armigera (Hübner) (Lepidoptera: Noctuidae), on Different Host Plants. Env. Entomol. 33(6): 1570-1576

$\mathrm{Nu} \mathrm{Nu}$ Yi and Win Kyi (2000) Biological control of cotton bollworm and chickpea pod borer, Helicoverpa armigera y using predator Eocanthecona furcellata and parasitoid Campoletis chlorideae. In proceeding of the annual research conference, April 3-5, 2000, Yangon, Myanmar. 58-74 pp.

Mahdian, K., I. Vantornhout, L. Tirry and P. De Clercq (2006) Effects of temperature on predation by the stinkbugs Picromerus bidens and Podisus maculiventris (Heteroptera: Pentatomidae) on noctuid caterpillars. Bulletin of Entomological Research 96:489-496

Marston, N. L., G. T.Schmidt, K. D. Biever, and W. A. Dickerson, (1978) Reaction of five species of soybean caterpillars to attack by the predator, Podisus maculiventris. Env. Entomol. 7: 53-56.

MCSE (1999) Main Cotton Pest in Myanmar and their Control (in Myanmar), Myanma Cotton and Sericulture Enterprise, pp 40

Medeiros, R. S., F.S. Ramalho, J. C. Zanuncio, and J. E: Serrao (2003a) Effect of temperature on life table parameters of Podisus nigrispinus (Het.: Pentatomidae) feb with Alabama argillacea (Lepidoptera: Notodontidae) larvae, J. Appl. Ent: 127: 209-213 
Medeiros, R. S., F.S. Ramalho, J. E: Serrao, and J. C. Zanuncio (2003b) Temperature influence on reproduction of Podisus nigrispinus, a predator of the noctuid larva Alabama argillacea. Biocontrol 48: 695-704

Mohaghegh, J., P. De Clercq, and L. Tirry (2001) Functional response of the predators Podisus maculiventris (Say) and Podisus nigrispinus (Dallas) (Het.: Pentatomidae) to the beet armyworm, Spodoptera exigua (Hübner) (Het.: Pentatomidae): effect of temperature

Morris, H. and D. F. Waterhouse (2001) The distribution and important of arthropod pest and weeds of agriculture in Myanmar. ACIAR Monograph No. 67,73 pp.

Myat Htwe and Mya Maung (1992) National IPM programme of the Union of Myanmar. In Ooi, P.A.C.et. al. (ed) (1992) IPM in the Asia-Pacific Region. Proc. of the Conf. on IPM in the Asia-Pacific Region, 23-27, September 1999, Kuala Lumpur, Malaysia

Myintzu, P. H. (1974) Myanma War ( in Myanmar language), Yangon, pp 186

Nu Nu Yi and Win Kyi (2000) Biological control of cotton bollworm and chickpea pod borer, Helicoverpa armigera y using predator Eocanthecona furcellata and parasitoid Campoletis chlorideae. In proceeding of the annual research conference, April 3-5, 2000, Yangon, Myanmar. 58-74 pp.

Persons, F.S. (1940) Investigations on the bollworm, Heliothis armigera, Hübn, Part III. Relationships between oviposition and the flowering curves of foodplants. Bull Entomol. Res. 31:147-177

Pearson, E.O. (1958) The insect pest of cotton in tropical Africa. Comonweath Inst. Entomol. London.335 pp. 
Perdikis, D.CH., D.P. Lykouressis, and L.P. Economou (2004) Influence of lightdark phase, host plant, temperature, and their interactions on an insect predator. Env. Entomol. 33(5): 1137-1144

Pfannenstiel, R. S., R. E. Hunt and K. V. Yeargan (1995) Orientation of a Hemipteran predator to vibrations produced by feeding caterpillars. Journal of Insect Behavior 8(1): 1-9

Prasad, D., K. M. Singh, R. N. Singh, and D. N. Mehto (1983) A new predator of new pest of jasmine in Delhi. Bull. Entomol. 24: 140-141.

Rawat, R.R., S.S. Jakhmola and U.R. Sahu (1970) Assessment of losses of hybrid sorghum CSH1 to earhead caterpillars, and comparison of insecticidal controls. PANS 16(2):367-369

Reed, W. and C. S. Pawar, (1982) Heliothis: a global problem. Proc. Int. Workshop Heliothis Management, Patancheru, India ICRISAT. 418 pp.

Roome, R.E. (1975) Activity of adut Heliothis armigera (Hübner) (Lepidoptera: Noctuidae) with reference to the flowering of sorghum and maize in Bostswana. Bull. Entomol. Res. 65: 523-530

Saleh, A. and C. Sengonca (2003) Effects of different high constant and alternating temperatures on the development and prey consumption of Dicyphus tamaninii Wagner (Heteroptera, Miridae) with Aphis gossypii Glover (Homoptera, Aphididae) as prey. Journal of Pest Science 76(5): 118-123

Saxena, J.D., S. Rai, K.M. Srivastava \& S.R. Sinha (1989) Resistance in the field population of the diamondback moth to some commonly used synthetic pyrethroids. Indian J. Entomol. 51: 265-268

Schneider, J.C., J.H. Benedict, F. Gould, W.R. Meredith, M.F. Schuster, G.R.Zummo (1986) Interaction of Heliothis with its host plants. In : S.J. Johnson, E.G. King, J.R. Bradley (Eds.), Theory and Tactics of Heliothis population management: I - Cultural and Biological control. Southern 
Cooperative Series Bulletin 316, Stillwater: Oklahoma State University, 2-21 pp.

Shanower. T.G., T.G. Kelley \& S.E. Cowgill (1997) Development of effective and aenvironmentally sound strategies to control Helicoverpa armigera in Pigeonpea and Chickpea production systems. In: R.K. Saini (ed), Tropical Entomology 1994. Nairobi, Kenya. ICIPE Science Press, 255-276 pp.

Shanower, T.G. and J. Romeis (1999) Insect pests of pigeonpea and their management. Ann. Rev. Entomol. 44: 77-96

Sharmad, H., G. Pampapathy, S. Lanka, and Ridsdill-Smith, T. (2005) Antibiosis mechanism of resistance to pod borer, Helicoverpa armigera in wild relatives of chickpea Euphytica 142(1-2): 107-117(11)

Solomon, M. E.(1949) The natural control of animal populations. J. Anim. Ecol. 18: 1-35

Shorey, H.H. \& R.L. Hala (1965) Mass rearing of some noctuid species on a simple artificial medium. J. Econ. Entomol. 58: 522-544.

SPSS Inc., (2004). Systat 11 for Windows; SPSS Inc., Chicago, USA.

Srinivasan, P.M. (1959) Control of fruit borer H.armigera (Hb.) on tomato. Indian Journal of Hoticulture 16: 187-188.

Stamp, N. E., T. Erskine, and C. J. Paradise (1991) Effects of rutin-fed caterpillars on an invertebrate predator. Oecologia, 88, 289-295

Stathas, G. J. (2000) The effect of temperature on the development of the predator Rhyzobius lophanthae and its phenoloy in Greece, Biocontrol 45: 439-451

Sun C-N 1992. Insecticide resistance in diamondback moth. In: Talekar NS ed. Diamondback moth and other crucifera pests. Proceedings of the 2nd 
International Workshop, Taiwan, December 1990, AVRDC publication. 419$426 \mathrm{pp}$.

Tabashnik B. E., N. L. Cushing, M. W. Johnson (1987) Diamondback moth (Lepidoptera: Plutellidae) resistance to insecticides in Hawaii: Intra-island variation and cross-resistance. J. Econ. Entomol. 80: 1091-1099.

Tan, S., X. Chen, A. Zhang and D. Li (2001) Isolation and characterization of DNA microsatellite from cotton bollworm (Helicoverpa armigera, Hübner)

Tipping, P. W., Carol A. Holko, Aref A. Abdul-Baki, and Jeffrey R. Aldrich (1999) Evaluating Edovum puttleri Grissell and Podisus maculiventris (Say) for augmentive biological control of Colorado potato beetles in tomatoes. Biological Control 16 (1): 35-42

Thompson J. N.(1988) Evolutionary ecology of the relationship between oviposition preference and performance of offspring in phytophagous insects. Entomol. Exp. Appli. 47:3-14

Torres, J. B., J.C. Zanuncio and H.N. Oliveira (1998) Nymphal development and adult reproduction of the stinkbug predator Podisus nigrispinus (Heteroptera: Pentatomidae) under fluctuating temperatures. J. Appl. Entomol. 122: 509514

Uygun, N. and R. Atlihan (2000) The effect of temperature on development and fecundity of Scymnus levaillanti. Biocontrol 45: 453-462

Van den Bosch, R. and K.S. Hagen (1966) Predaceous and parasitic arthropods in California cotton fields. California Agricultural Experiment Station Bulletin 820. University of California, Berkeley, Calif, USA. 32 pp.

Van den Bosch, R., T.F. Leigh, D. Gonzalez and R.E. Stinner (1969) Cage studies on predators of the bollworm in cotton. J. Econ. Entomol. 62: 1486-1489

Wardhaugh, K.G., P. M. Room, L.R. Greenup (1980) The incidence of Heliothis armigera (Hübner) and $H$. punctigera Wallengren (Lepidoptera: Noctuidae) 
on cotton and other host plants in the Namoi Valley of New South Wales. Bull. Entomol. Res. 70: 113-131

Westich, R. and Judith Hough-Goldstein (2001) Temperature and host plant effects on predatory stink bugs for augmentative biological control. Biological Control, 21 (2): 160-167

Yasuda, T. and S. Wakamura (1992) Rearing of the predatory stink bug Eocanthecona furcellata (Wolff) (Hemiptera: Pentatomidae), on frozen larvae of Spodoptera litura (Fabricius) (Lepidoptera: Noctuidae). Appl. Entomol. Zool., 27:303-305

Yasuda, T. and S. Wakamura (1996) Behavioral responses in prey location of the predatory stink bug Eocanthecona furcellata, to chemical cueee in the larvae of Spodoptera litura. Entomol. Exp. Appl. 81: 91-96

Yasuda, T. (1997) Chemical cues from the Spodoptera litura larvae elicit preylocating behavior of generalist predatory stink bug Eocanthecona furcellata. Entomol. Exp.Appl.82: 349-354

Yasuda, T. (1998a) Effects of $(E)$ - Phytol of several lepidopteran species in preylocating behavior of generalist predatory stink bug Eocanthecona furcellata (Heteroptera: Pentatomidae). Entomol.Sci. 1:159-164

Yasuda, T. (1998b) Role of chlorophyll content of prey diets in prey- locating behavior of generalist predatory stink bug Eocanthecona furcellata. Entomol. Exp.Appl.86: 119-124

Yasuda, T. (2000) Role of semiochemicals in prey- locating behavior of a generalist predatory stink bug Eocanthecona furcellata (Heteroptera: Pentatomidae). Jpn. Agri. Res. Q. 34:15-20

Zalucki, M. P., G. Daglish, S. Firempong, and P. Twine (1986) The biology and ecology of Heliothis armigera (Hübner) and $H$. punctigera Wallengern 
(Lepidoptera: Noctuidae) in Australia: What do we know? Aust. J. Zool. 34: 779- 814 


\section{SUMMARY}

The American Cotton Bollworm (Helicoverpa armigera Hübner)(ABW) is one of the most serious pests of cultivated crops, especially in cotton in Myanmar. Insecticide applications to control this insect pest are too expensive for smallholder farmers; moreover residues are frequently washed from the plants by continuously light rainfalls in Myanmar. An alternative approach for controlling the herbivorous pests aims at enhancing the abundance of predators, naturally occurring in this crop. A number of promising natural enemies were identified in the cotton agroecosystems, and among them the predatory bug Eocanthecona furcellata (Wolff)(EO) holds potential for controlling the American Cotton Bollworm.

Diamondback moth (Plutella xylostella L.)(DBM) is most damaging vegetable pest not only in Myanmar than also in most tropical countries, where cabbage plants and ideal temperatures for high DBM populations prevail throughout the year. Due to frequent insecticide applications development of resistance towards specific compounds, including Bacillus thuringiensis, has been reported in several regions. We wanted to experienced a predatory bug (Eocanthecona furcellata Wolff), native to Myanmar and commonly found in the field, for its effectiveness to prey on DBM. Therefore, this study aimed at testing the effectiveness of biological control measures by:

1. Testing the effect of host plants on the oviposition preference and larvae performance of American Bollworm Helicoverpa armigera

Chickpea, cotton and tomato, and wild cabbage plants were used for ovipositing preference and larvae performance of American Bollworm Helicoverpa armigera. The highest numbers of $H$. armigera eggs was recorded on chickpea plants followed by tomato, cotton and cabbage plants. The best performance of $H$. armigera larvae was recorded on artificial diet followed by wild cabbage, cotton, chickpea and tomato plants. 
2. Testing the predation efficacy of E. furcellata on American Bollworm Helicoverpa armigera

Predation efficacy of EO was tested with American Bollworm from four different host plants (Cabbage, Cotton, Chickpea and Tomato) and larvae reared on artificial diet. Majority of EO (30-60 \%) directly approached towards cotton plants eating ABW larvae. When ABW larvae and their faeces were wrapped with Para film 'M', the prey selecting efficacy was reduced up to $20-40 \%$.

3. Evaluating the effect of temperature and prey density on the predation efficacy of $E$. furcellata

Developmental time and predation efficacy were tested with three different temperatures and eight prey densities; and four extreme temperatures. Developmental time was significantly shorter in high temperature $\left(35^{\circ} \mathrm{C}\right)$ but the highest predation rate of EO was found at $30^{\circ} \mathrm{C}$. Developmental time increased with increasing prey density but prey consumption percent reduced with increasing prey density. Predation rate increased with nymph instars of EO and the highest predation efficacy was found on $5^{\text {th }}$ instar EO nymph at $30^{\circ} \mathrm{C}$. EO could not survive at two extreme temperatures $\left(15^{\circ} \mathrm{C}\right.$ and $\left.40^{\circ} \mathrm{C}\right)$ and EO was able to survive at these two constant temperatures; however EO was unable to lay the eggs at $20^{\circ} \mathrm{C}$ and even though they could lay the eggs at $37^{\circ} \mathrm{C}$, no eggs was able to hatch to nymphs. Therefore no viable offspring were recorded in four tested extreme temperatures.

4. Testing the prey searching and feeding behavior of Eocanthecona furcellata under laboratory and greenhouse conditions

Prey searching and feeding behavior of EO was tested with two different preys (American bollworm ABW and Diamondback moth (DBM), two different host plants (cotton plant and wild cabbage plant) and three different conditions (normal plant, wounded plant, and insect infected plant) under laboratory condition and green house conditions. Searching time and prey consumption time of EO was significantly lower on ABW larvae than on DBM larvae. Searching time of EO on 
ABW larvae on the wild cabbage plant was significantly longer than on cotton plant but prey consumption of EO on ABW larvae was not significant on both host plants. Visiting time of predatory bug on the insect infested plant was significantly longer than on narmal plant and mechanical wounded plant.

5. Observing of host choice behavior of E. furcellata towards ABW and DBM larvae in Olfactometer

Host choice behavior of EO was studied in Olfactometer and the attractiveness \% of $\mathrm{ABW}$ and DBM were $43 \%$ and $30 \%$. The searching time of EO was not significantly different in both larvae. 
Appendix1. Developmental times (days) of Eocanthecona furcellata (EO) nymphs offered with eight different prey density and reared at three different temperatures

\begin{tabular}{|c|c|c|c|c|c|c|c|c|c|c|c|c|c|}
\hline \multirow[t]{2}{*}{ Tem: } & \multirow[t]{2}{*}{ Functions } & \multirow[t]{2}{*}{ EO Instar } & \multicolumn{8}{|c|}{$\begin{array}{l}\text { Prey Density } \\
\text { ( DBM larvae) }\end{array}$} & \multirow[t]{2}{*}{ df } & \multirow[t]{2}{*}{$\begin{array}{l}\text { F- } \\
\text { ratio }\end{array}$} & \multirow[t]{2}{*}{$\mathbf{P}$ * } \\
\hline & & & 1 & 2 & 3 & 4 & 5 & 6 & 8 & 10 & & & \\
\hline \multirow[t]{7}{*}{$25^{\circ} \mathrm{C}$} & \multirow{7}{*}{$\begin{array}{l}\text { Develop- } \\
\text { mental } \\
\text { Time (Days) } \\
\text { (mean } \pm \text { SE) }\end{array}$} & egg & \multicolumn{11}{|c|}{$10.84 \pm 0.07$} \\
\hline & & 1st & \multicolumn{8}{|c|}{$3.91 \pm 0.05$} & \multirow[b]{2}{*}{7} & \multirow[b]{2}{*}{27.43} & \multirow[b]{2}{*}{0.000} \\
\hline & & $2^{\text {nd }}$ & $\begin{array}{c}6.00 \\
\pm 0.41 \mathrm{a} \\
\end{array}$ & $\begin{array}{c}5.25 \\
\pm 0.25 \mathrm{a}\end{array}$ & $\begin{array}{c}5.25 \\
\pm 0.25 a\end{array}$ & $\begin{array}{c}5.25 \\
\pm 0.25 \mathrm{a} \\
\end{array}$ & \begin{tabular}{|c|}
3.50 \\
$\pm 0.29 \mathrm{~b}$
\end{tabular} & \begin{tabular}{|c}
2.75 \\
$\pm 0.25 b$ \\
\end{tabular} & $\begin{array}{c}3.00 \\
\pm 0.00 \mathrm{~b} \\
\end{array}$ & $\begin{array}{c}3.00 \\
\pm 0.00 \mathrm{~b}\end{array}$ & & & \\
\hline & & $3^{\text {rd }}$ & $\begin{array}{c}4.00 \\
\pm 0.58 \mathrm{a}\end{array}$ & $\begin{array}{c}4.00 \\
\pm 0.41 \mathrm{a}\end{array}$ & $\begin{array}{c}3.25 \\
\pm 0.25 \mathrm{a} \\
\end{array}$ & \begin{tabular}{|c|}
3.25 \\
$\pm 0.48 \mathrm{a}$
\end{tabular} & \begin{tabular}{|c|}
4.00 \\
$\pm 0.00 \mathrm{a}$ \\
\end{tabular} & \begin{tabular}{|c|}
3.25 \\
$\pm 0.25 \mathrm{a}$ \\
\end{tabular} & $\begin{array}{c}2.75 \\
\pm 0.25 \mathrm{a}\end{array}$ & $\begin{array}{c}3.00 \\
\pm 0.00 \mathrm{a} \\
\end{array}$ & 7 & 2.143 & 0.078 \\
\hline & & $4^{\text {th }}$ & $\begin{array}{c}4.00 \\
\pm 0.00 \mathrm{a}\end{array}$ & $\begin{array}{c}4.00 \\
\pm 0.00 \mathrm{a}\end{array}$ & $\begin{array}{c}4.50 \\
\pm 0.29 \mathrm{a}\end{array}$ & $\begin{array}{c}4.00 \\
\pm 0.00 \mathrm{a}\end{array}$ & $\begin{array}{c}4.25 \\
\pm 0.25 \mathrm{a}\end{array}$ & $\begin{array}{c}3.00 \\
\pm 0.00 \mathrm{~b}\end{array}$ & $\begin{array}{c}3.00 \\
\pm 0.00 \mathrm{~b}\end{array}$ & $\begin{array}{c}3.00 \\
\pm 0.00 \mathrm{~b}\end{array}$ & 7 & 21.00 & 0.000 \\
\hline & & $5^{\text {th }}$ & $\begin{array}{c}6.25 \\
\pm 0.25 \mathrm{a}\end{array}$ & $\begin{array}{c}6.25 \\
\pm 0.25 a\end{array}$ & $\begin{array}{c}6.50 \\
\pm 0.29 \mathrm{a}\end{array}$ & $\begin{array}{c}6.00 \\
\pm 0.00 \mathrm{a}\end{array}$ & $\begin{array}{c}6.00 \\
\pm 0.00 \mathrm{a}\end{array}$ & $\begin{array}{c}6.00 \\
\pm 0.00 \mathrm{~b}\end{array}$ & $\begin{array}{c}7.00 \\
\pm 0.00 \mathrm{~b}\end{array}$ & $\begin{array}{c}7.00 \\
\pm 0.00 \mathrm{~b}\end{array}$ & 7 & 12.18 & 0.000 \\
\hline & & $\begin{array}{c}\text { Total } \\
\text { Life day }\end{array}$ & $\begin{array}{c}35.25 \\
\pm 0.75 a\end{array}$ & $\begin{array}{r}34.75 \\
\pm 0.48 \mathrm{a}\end{array}$ & $\begin{array}{c}34.00 \\
\pm 0.00 \mathrm{a} \\
\end{array}$ & $\begin{array}{c}33.50 \\
\pm 0.29 \mathrm{a}\end{array}$ & \begin{tabular}{|c|}
32.75 \\
$\pm 0.48 \mathrm{ab}$ \\
\end{tabular} & $\begin{array}{c}31.00 \\
\pm 0.41 \mathrm{~b} \\
\end{array}$ & $\begin{array}{r}30.75 \\
\pm 0.25 \mathrm{~b}\end{array}$ & $\begin{array}{c}31.00 \\
\pm 0.00 \mathrm{~b}\end{array}$ & 7 & 19.18 & 0.000 \\
\hline \multirow[t]{7}{*}{$30^{\circ} \mathrm{C}$} & \multirow{7}{*}{\begin{tabular}{|l} 
Develop- \\
mental \\
Time (Days) \\
(mean \pm SE)
\end{tabular}} & egg & \multicolumn{11}{|c|}{$7.12 \pm 0.08$} \\
\hline & & 1st & \multicolumn{11}{|c|}{$2.09 \pm 0.52$} \\
\hline & & $2^{\text {nd }}$ & $\begin{array}{c}2.00 \\
\pm 0.00 \mathrm{a}\end{array}$ & $\begin{array}{r}1.75 \\
\pm 0.25 \mathrm{a}\end{array}$ & $\begin{array}{c}1.00 \\
\pm 0.00 \mathrm{ab}\end{array}$ & \begin{tabular}{|c}
1.00 \\
$\pm 0.00 \mathrm{ab}$
\end{tabular} & $\begin{array}{c}1.00 \\
\pm 0.00 \mathrm{ab}\end{array}$ & $\begin{array}{c}1.50 \\
\pm 0.29 \mathrm{a}\end{array}$ & $\begin{array}{c}1.75 \\
\pm 0.25 \mathrm{a}\end{array}$ & $\begin{array}{c}1.75 \\
\pm 0.25 \mathrm{a}\end{array}$ & 7 & 4.978 & 0.001 \\
\hline & & $3^{\text {rd }}$ & $\begin{array}{c}2.25 \\
\pm 0.25 \mathrm{a}\end{array}$ & $\begin{array}{r}2.25 \\
\pm 0.25 \mathrm{a}\end{array}$ & $\begin{array}{c}2.75 \\
\pm 0.25 \mathrm{ab}\end{array}$ & $\begin{array}{c}2.25 \\
\pm 0.25 \mathrm{a}\end{array}$ & $\begin{array}{c}2.50 \\
\pm 0.29 \mathrm{a}\end{array}$ & $\begin{array}{c}1.50 \\
\pm 0.29 \mathrm{a}\end{array}$ & $\begin{array}{c}1.25 \pm 0 \\
25 \mathrm{ab}\end{array}$ & $\begin{array}{c}1.25 \\
\pm 0.25 \mathrm{~b}\end{array}$ & 7 & 5.011 & 0.001 \\
\hline & & $4^{\text {th }}$ & $\begin{array}{c}4.00 \\
\pm 0.00 \mathrm{a}\end{array}$ & $\begin{array}{c}3.25 \\
\pm 0.48 \mathrm{a}\end{array}$ & $\begin{array}{c}3.00 \\
\pm 0.41 \mathrm{a}\end{array}$ & $\begin{array}{c}2.75 \\
\pm 0.25 \mathrm{a}\end{array}$ & $\begin{array}{c}2.50 \\
\pm 0.29 \mathrm{a}\end{array}$ & $\begin{array}{c}2.50 \\
\pm 0.29 \mathrm{a}\end{array}$ & $\begin{array}{r}2.75 \\
\pm 0.25 \mathrm{a}\end{array}$ & $\begin{array}{c}2.75 \\
\pm 0.25 \mathrm{a}\end{array}$ & 7 & 2.619 & 0.037 \\
\hline & & $5^{\text {th }}$ & \begin{tabular}{|c|}
7.00 \\
$\pm 0.41 \mathrm{a}$
\end{tabular} & $\begin{array}{r}6.25 \\
\pm 0.25 \mathrm{a}\end{array}$ & $\begin{array}{c}5.00 \\
\pm 0.41 \mathrm{ab}\end{array}$ & $\begin{array}{c}4.50 \\
\pm 0.29 \mathrm{~b}\end{array}$ & $\begin{array}{c}4.25 \\
\pm 0.25 \mathrm{~b}\end{array}$ & $\begin{array}{c}4.00 \\
\pm 0.00 \mathrm{~b}\end{array}$ & $\begin{array}{c}4.00 \\
\pm 0.00 \mathrm{~b}\end{array}$ & $\begin{array}{c}3.50 \\
\pm 0.29 \mathrm{~b}\end{array}$ & 7 & 18.91 & 0.000 \\
\hline & & $\begin{array}{l}\text { Total } \\
\text { Life day }\end{array}$ & $\begin{array}{c}25.25 \\
\pm 0.48 \mathrm{a} \\
\end{array}$ & $\begin{array}{r}23.50 \\
\pm 0.29 a\end{array}$ & $\begin{array}{c}21.75 \\
\pm 0.75 \mathrm{ab}\end{array}$ & \begin{tabular}{|c|}
20.50 \\
$\pm 0.29 b$
\end{tabular} & \begin{tabular}{|c|}
20.25 \\
$\pm 0.25 b$
\end{tabular} & $\begin{array}{c}19.50 \\
\pm 0.29 b\end{array}$ & $\begin{array}{r}19.75 \\
\pm 0.25 b\end{array}$ & $\begin{array}{c}19.25 \\
\pm 0.25 b\end{array}$ & 7 & 29.92 & 0.000 \\
\hline \multirow[t]{7}{*}{$35^{\circ} \mathrm{C}$} & \multirow{7}{*}{$\begin{array}{l}\text { Develop - } \\
\text { mental } \\
\text { Time (Days) } \\
\text { (mean } \pm S E \text { ) }\end{array}$} & egg & \multicolumn{11}{|c|}{$4.813 \pm 0.07$} \\
\hline & & 1st & \multicolumn{11}{|c|}{$1.062 \pm 0.04$} \\
\hline & & $2^{\text {nd }}$ & $\begin{array}{c}1.00 \\
\pm 0.00 \mathrm{a} \\
\end{array}$ & $\begin{array}{r}1.00 \\
\pm 0.00 \mathrm{a} \\
\end{array}$ & $\begin{array}{c}1.00 \\
\pm 0.00 \mathrm{a} \\
\end{array}$ & $\begin{array}{c}1.00 \\
\pm 0.00 \mathrm{a} \\
\end{array}$ & $\begin{array}{c}1.00 \\
\pm 0.00 \mathrm{a} \\
\end{array}$ & $\begin{array}{c}1.00 \pm 0 . \\
00 \mathrm{a}\end{array}$ & $\begin{array}{c}1.25 \pm 0 \\
25 \mathrm{a}\end{array}$ & \begin{tabular}{|c|}
1.00 \\
$\pm 0.00 \mathrm{a}$ \\
\end{tabular} & 7 & 1.000 & 0.455 \\
\hline & & $3^{\text {rd }}$ & \begin{tabular}{|c|}
2.50 \\
$\pm 0.29 \mathrm{a}$ \\
\end{tabular} & $\begin{array}{r}2.25 \\
\pm 0.25 a\end{array}$ & \begin{tabular}{|c|}
2.00 \\
$\pm 0.41 \mathrm{a}$ \\
\end{tabular} & $\begin{array}{c}2.00 \\
\pm 0.00 \mathrm{a} \\
\end{array}$ & $\begin{array}{c}1.25 \\
\pm 0.25 \mathrm{a} \\
\end{array}$ & $\begin{array}{c}2.00 \pm 0 . \\
00 a\end{array}$ & $\begin{array}{c}1.50 \pm 0 \\
29 a\end{array}$ & $\begin{array}{c}1.50 \\
\pm 0.29 \mathrm{a} \\
\end{array}$ & 7 & 2.637 & 0.036 \\
\hline & & $4^{\text {th }}$ & \begin{tabular}{|c|}
3.25 \\
$\pm 0.25 a$ \\
\end{tabular} & $\begin{array}{c}3.00 \\
\pm 0.41 \mathrm{a} \\
\end{array}$ & $\begin{array}{c}2.50 \\
\pm 0.29 \mathrm{a} \\
\end{array}$ & $\begin{array}{c}2.00 \\
\pm 0.00 \mathrm{a} \\
\end{array}$ & \begin{tabular}{|c|}
2.00 \\
$\pm 0.00 \mathrm{a}$ \\
\end{tabular} & $\begin{array}{c}2.50 \pm 0 . \\
29 a\end{array}$ & $\begin{array}{c}2.75 \pm 0 \\
48 \mathrm{a}\end{array}$ & $\begin{array}{c}2.00 \pm 0 \\
00 a\end{array}$ & 7 & 2.971 & 0.022 \\
\hline & & $5^{\text {th }}$ & \begin{tabular}{|c|}
6.75 \\
$\pm 0.48 \mathrm{a}$
\end{tabular} & $\begin{array}{c}4.75 \\
\pm 0.48 \mathrm{a} \\
\mathrm{b}\end{array}$ & \begin{tabular}{|c|}
4.25 \\
$\pm 0.25 \mathrm{~b}$
\end{tabular} & \begin{tabular}{|c|}
3.75 \\
$\pm 0.25 b$
\end{tabular} & \begin{tabular}{|c|}
4.50 \\
$\pm 0.29 \mathrm{~b}$
\end{tabular} & \begin{tabular}{|c|}
4.75 \\
$\pm 0.25 b$
\end{tabular} & $\begin{array}{c}4.25 \\
\pm 0.25 b\end{array}$ & \begin{tabular}{|c|}
4.25 \\
$\pm 0.25 b$
\end{tabular} & 7 & 7.683 & 0.000 \\
\hline & & $\begin{array}{c}\text { Total } \\
\text { Life day }\end{array}$ & $\begin{array}{c}19.50 \\
\pm 0.96 \mathrm{a}\end{array}$ & $\begin{array}{r}17.00 \\
\pm 1.08 \mathrm{a}\end{array}$ & $\begin{array}{c}15.75 \\
\pm 0.48 \mathrm{ab}\end{array}$ & \begin{tabular}{|c|}
14.75 \\
$\pm 0.25 \mathrm{ab}$
\end{tabular} & $\begin{array}{r}14.75 \\
\pm 0.25 \mathrm{ab}\end{array}$ & $\begin{array}{c}16.25 \\
\pm 0.25 \mathrm{ab}\end{array}$ & $\begin{array}{r}15.75 \\
\pm 0.63 \mathrm{ab}\end{array}$ & $\begin{array}{c}14.75 \\
\pm 0.25 \mathrm{ab} \\
\end{array}$ & 7 & 6.990 & 0.000 \\
\hline
\end{tabular}

* Significance level within the same rows by ANOVA. Means ( \pm SE) in a row followed by the same letters indicate no significant differences and different letters indicate significant differences between prey densities (ANOVA, Bonferroi adjustment) 
Appendix 2. Daily prey consumption (DBM larvae) of Eocanthecona furcellata (EO) nymphs offered with eight different prey density and reared at three different

\section{temperatures}

\begin{tabular}{|c|c|c|c|c|c|c|c|c|c|c|c|c|c|}
\hline \multirow[t]{2}{*}{ Tem: } & \multirow[t]{2}{*}{$\begin{array}{c}\text { Function } \\
s \text { of EO }\end{array}$} & \multirow[t]{2}{*}{$\begin{array}{c}\text { EO } \\
\text { Instar }\end{array}$} & \multicolumn{8}{|c|}{$\begin{array}{l}\text { Prey Density } \\
\text { ( DBM larvae) }\end{array}$} & \multirow[t]{2}{*}{ df } & \multirow{2}{*}{$\begin{array}{l}\text { F- } \\
\text { rati } \\
0\end{array}$} & \multirow[t]{2}{*}{$\mathbf{P}$} \\
\hline & & & 1 & 2 & 3 & 4 & 5 & 6 & 8 & 10 & & & \\
\hline \multirow[t]{6}{*}{$25^{\circ} \mathrm{C}$} & \multirow{6}{*}{$\begin{array}{l}\text { Daily prey } \\
\text { consumption } \\
\text { (DBM } \\
\text { larvae) }\end{array}$} & $2^{\text {nd }}$ & $\begin{array}{c}0.96 \\
\pm 0.04 \mathrm{a}\end{array}$ & $\begin{array}{c}1.58 \\
\pm 0.09 \mathrm{a}\end{array}$ & $\begin{array}{c}2.46 \\
\pm 0.21 \mathrm{ab}\end{array}$ & $\begin{array}{c}3.18 \\
\pm 0.18 \mathrm{~b}\end{array}$ & $\begin{array}{c}4.04 \\
\pm 0.22 \mathrm{~b}\end{array}$ & $\begin{array}{c}2.46 \\
\pm 0.31 \mathrm{ab}\end{array}$ & $\begin{array}{c}3.08 \\
\pm 0.16 \mathrm{~b}\end{array}$ & 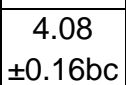 & 7 & 34.47 & 0.00 \\
\hline & & $3^{\text {rd }}$ & $\begin{array}{c}0.95 \\
\pm 0.05 a\end{array}$ & $\begin{array}{c}1.72 \\
\pm 0.14 \mathrm{a}\end{array}$ & $\begin{array}{c}2.83 \\
\pm 0.17 \mathrm{ab}\end{array}$ & $\begin{array}{c}3.94 \\
\pm 0.06 \mathrm{ab}\end{array}$ & \begin{tabular}{|c|}
4.88 \\
$\pm 0.07 \mathrm{c}$
\end{tabular} & $\begin{array}{c}2.31 \\
\pm 0.14 \mathrm{ab}\end{array}$ & $\begin{array}{c}3.54 \\
\pm 0.33 \mathrm{bc}\end{array}$ & \begin{tabular}{|c|}
4.25 \\
$\pm 0.44 \mathrm{bc}$
\end{tabular} & 7 & 37.97 & 0.00 \\
\hline & & $4^{\text {th }}$ & $\begin{array}{c}1.00 \\
\pm 0.00 \mathrm{a}\end{array}$ & $\begin{array}{c}1.63 \\
\pm 0.07 \mathrm{a}\end{array}$ & $\begin{array}{c}2.80 \\
\pm 0.14 \mathrm{ab}\end{array}$ & $\begin{array}{c}3.25 \\
\pm 0.14 \mathrm{ab} \\
\end{array}$ & $\begin{array}{c}3.91 \\
\pm 0.32 \mathrm{ab} \\
\end{array}$ & $\begin{array}{c}3.92 \\
\pm 0.34 \mathrm{ab} \\
\end{array}$ & $\begin{array}{c}6.00 \\
\pm 0.62 \mathrm{c} \\
\end{array}$ & $\begin{array}{c}6.00 \\
\pm 0.38 \mathrm{c} \\
\end{array}$ & 7 & 33.02 & 0.00 \\
\hline & & $5^{\text {th }}$ & $\begin{array}{c}1.00 \\
\pm 0.00 \mathrm{a}\end{array}$ & $\begin{array}{c}1.93 \\
\pm 0.07 \mathrm{~b}\end{array}$ & $\begin{array}{c}2.54 \\
\pm 0.18 \mathrm{~b}\end{array}$ & $\begin{array}{c}3.29 \\
\pm 0.22 \mathrm{bc} \\
\end{array}$ & $\begin{array}{c}4.00 \\
\pm 0.15 \mathrm{c} \\
\end{array}$ & $\begin{array}{c}5.14 \\
\pm 0.10 \mathrm{~d} \\
\end{array}$ & $\begin{array}{c}6.71 \\
\pm 0.13 \mathrm{e} \\
\end{array}$ & $\begin{array}{c}8.46 \\
\pm 0.27 f \\
\end{array}$ & 7 & 241.1 & 0.00 \\
\hline & & $\begin{array}{l}\text { Mean } \\
\text { con. }\end{array}$ & $\begin{array}{c}0.98 \\
\pm 0.01 \mathrm{a}\end{array}$ & $\begin{array}{c}1.74 \\
\pm 0.03 \mathrm{~b}\end{array}$ & \begin{tabular}{|c|}
2.63 \\
$\pm 0.11 b$
\end{tabular} & $\begin{array}{c}3.37 \\
\pm 0.03 \mathrm{~b}\end{array}$ & $\begin{array}{c}4.19 \\
\pm 0.10 \mathrm{~b}\end{array}$ & $\begin{array}{c}3.87 \\
\pm 0.10 \mathrm{c}\end{array}$ & $\begin{array}{c}5.32 \\
\pm 0.13 \mathrm{c}\end{array}$ & $\begin{array}{c}6.39 \\
\pm 0.18 \mathrm{c}\end{array}$ & 7 & 312.7 & 0.00 \\
\hline & & $\begin{array}{l}\text { Total } \\
\text { con. }\end{array}$ & $\begin{array}{c}18.25 \\
\pm 0.25 \mathrm{a}\end{array}$ & $\begin{array}{c}31.25 \\
\pm 0.63 \mathrm{~b} \\
\end{array}$ & \begin{tabular}{|c|}
47.00 \\
$\pm 1.47 \mathrm{c}$
\end{tabular} & $\begin{array}{l}62.25 \\
\pm 0.85\end{array}$ & $\begin{array}{c}74.25 \\
\pm 1.44 \mathrm{e} \\
\end{array}$ & $\begin{array}{c}62.00 \\
\pm 2.42 \mathrm{~d} \\
\end{array}$ & $\begin{array}{c}83.75 \\
\pm 2.02 f \\
\end{array}$ & $\begin{array}{c}102.3 \\
\pm 2.84 \mathrm{~g} \\
\end{array}$ & 7 & 259.1 & 0.00 \\
\hline \multirow[t]{6}{*}{$30^{\circ} \mathrm{C}$} & \multirow{6}{*}{\begin{tabular}{|c|} 
Daily prey \\
consumption \\
(DBM \\
larvae)
\end{tabular}} & $2^{\text {nd }}$ & $\begin{array}{c}1.00 \\
\pm 0.00 \mathrm{a}\end{array}$ & $\begin{array}{c}1.38 \\
\pm 0.24 \mathrm{a} \\
\end{array}$ & \begin{tabular}{|c|}
2.25 \\
$\pm 0.48 \mathrm{a}$ \\
\end{tabular} & 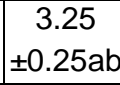 & $\begin{array}{c}3.75 \\
\pm 0.25 \mathrm{ab} \\
\end{array}$ & $\begin{array}{c}5.63 \\
\pm 0.24 \mathrm{c}\end{array}$ & $\begin{array}{c}4.00 \\
\pm 0.20 \mathrm{ab} \\
\end{array}$ & $\begin{array}{c}5.88 \\
\pm 0.75 \mathrm{c} \\
\end{array}$ & 7 & 24.37 & 0.00 \\
\hline & & $3^{\text {rd }}$ & $\begin{array}{c}1.00 \\
\pm 0.00 \mathrm{a}\end{array}$ & $\begin{array}{c}1.92 \\
\pm 0.08 \mathrm{a}\end{array}$ & $\begin{array}{c}3.00 \\
\pm 0.00 \mathrm{a}\end{array}$ & \begin{tabular}{|c|}
3.63 \\
$\pm 0.24 \mathrm{ab}$ \\
\end{tabular} & $\begin{array}{c}4.33 \\
\pm 0.30 \mathrm{bc}\end{array}$ & $\begin{array}{c}5.50 \\
\pm 0.50 \mathrm{~cd}\end{array}$ & $\begin{array}{c}5.13 \\
\pm 0.52 \mathrm{c}\end{array}$ & $\begin{array}{c}5.88 \\
\pm 0.92 \mathrm{~d}\end{array}$ & 7 & 15.99 & 0.00 \\
\hline & & $4^{\text {th }}$ & $\begin{array}{c}1.00 \\
\pm 0.00 \mathrm{a}\end{array}$ & $\begin{array}{c}2.00 \\
\pm 0.00 \mathrm{a}\end{array}$ & $\begin{array}{c}2.56 \\
\pm 0.36 \mathrm{a}\end{array}$ & 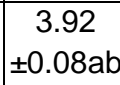 & $\begin{array}{c}5.00 \\
\pm 0.00 \mathrm{c}\end{array}$ & $\begin{array}{c}5.17 \\
\pm 0.17 \mathrm{c}\end{array}$ & $\begin{array}{c}5.88 \\
\pm 0.18 \mathrm{c}\end{array}$ & $\begin{array}{c}7.54 \\
\pm 0.83 \mathrm{~d}\end{array}$ & 7 & 42.86 & 0.00 \\
\hline & & $5^{\text {th }}$ & $\begin{array}{r}1.00 \\
\pm 0.00 \mathrm{a} \\
\end{array}$ & $\begin{array}{c}1.88 \\
\pm 0.08 \mathrm{a} \\
\end{array}$ & 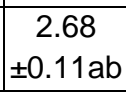 & $\begin{array}{c}3.16 \\
\pm 0.10 \mathrm{bc} \\
\end{array}$ & $\begin{array}{c}4.13 \\
\pm 0.07 d \\
\end{array}$ & $\begin{array}{c}5.31 \\
\pm 0.43 \mathrm{e} \\
\end{array}$ & $\begin{array}{c}6.50 \\
\pm 0.20 \mathrm{f} \\
\end{array}$ & $\begin{array}{c}9.65 \\
\pm 0.15 \mathrm{~g} \\
\end{array}$ & 7 & 227.2 & 0.00 \\
\hline & & $\begin{array}{l}\text { Mean } \\
\text { con. }\end{array}$ & $\begin{array}{c}1.00 \\
\pm 0.00 \mathrm{a}\end{array}$ & $\begin{array}{c}1.83 \\
\pm 0.05 a\end{array}$ & $\begin{array}{c}2.71 \\
\pm 0.12 b\end{array}$ & $\begin{array}{c}3.47 \\
\pm 0.06 \mathrm{~b}\end{array}$ & $\begin{array}{c}4.34 \\
\pm 0.07 \mathrm{c}\end{array}$ & $\begin{array}{c}5.33 \\
\pm 0.21 \mathrm{~d}\end{array}$ & $\begin{array}{c}5.70 \\
\pm 0.17 \mathrm{~d}\end{array}$ & \begin{tabular}{|c|}
7.63 \\
$\pm 0.36 \mathrm{e}$ \\
\end{tabular} & 7 & 169.5 & 0.00 \\
\hline & & $\begin{array}{l}\text { Total } \\
\text { con. }\end{array}$ & $\begin{array}{r}15.25 \\
\pm 0.48 \mathrm{a}\end{array}$ & $\begin{array}{c}24.75 \\
\pm 1.11 \mathrm{a}\end{array}$ & $\begin{array}{c}32.00 \\
\pm 3.19 \mathrm{~b}\end{array}$ & $\begin{array}{r}36.50 \\
\pm 1.50 \mathrm{bc}\end{array}$ & $\begin{array}{c}44.50 \\
\pm 1.04 \mathrm{~cd}\end{array}$ & $\begin{array}{c}50.75 \\
\pm 3.33 \mathrm{de}\end{array}$ & $\begin{array}{c}55.50 \\
\pm 1.04 \mathrm{e}\end{array}$ & $\begin{array}{c}70.50 \\
\pm 3.18 f\end{array}$ & 7 & 68.09 & 0.00 \\
\hline \multirow[t]{6}{*}{$35^{\circ} \mathrm{C}$} & \multirow{6}{*}{\begin{tabular}{|c|} 
Daily prey \\
consumption \\
(DBM \\
larvae)
\end{tabular}} & $2^{\text {nd }}$ & $\begin{array}{c}1.00 \\
\pm 0.00 \mathrm{a}\end{array}$ & $\begin{array}{c}1.25 \\
\pm 0.25 \mathrm{a}\end{array}$ & $\begin{array}{c}3.00 \\
\pm 0.00 \mathrm{~b}\end{array}$ & $\begin{array}{c}3.75 \\
\pm 0.25 \mathrm{bc}\end{array}$ & $\begin{array}{c}5.00 \\
\pm 0.00 \mathrm{c}\end{array}$ & $\begin{array}{c}4.75 \\
\pm 0.48 \mathrm{c}\end{array}$ & $\begin{array}{c}6.13 \\
\pm 0.31 \mathrm{~d}\end{array}$ & $\begin{array}{c}6.75 \\
\pm 0.48 \mathrm{~d}\end{array}$ & 7 & 52.34 & 0.00 \\
\hline & & $3^{\text {rd }}$ & $\begin{array}{c}1.00 \\
\pm 0.00 \mathrm{a}\end{array}$ & $\begin{array}{c}2.00 \\
\pm 0.00 \mathrm{a}\end{array}$ & $\begin{array}{c}3.00 \\
\pm 0.00 \mathrm{ab}\end{array}$ & \begin{tabular}{|c|}
3.88 \\
$\pm 0.13 b$
\end{tabular} & $\begin{array}{c}4.75 \\
\pm 0.25 \mathrm{bc}\end{array}$ & $\begin{array}{c}3.38 \\
\pm 0.24 \mathrm{~b}\end{array}$ & $\begin{array}{c}5.88 \\
\pm 0.77 \mathrm{~d}\end{array}$ & $\begin{array}{c}6.63 \\
\pm 0.24 \mathrm{e}\end{array}$ & 7 & 36.23 & 0.00 \\
\hline & & $4^{\text {th }}$ & $\begin{array}{c}1.00 \\
\pm 0.00 \mathrm{a}\end{array}$ & $\begin{array}{c}1.79 \\
\pm 0.13 a\end{array}$ & 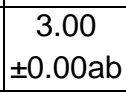 & $\begin{array}{c}4.00 \\
\pm 0.00 \mathrm{c} \\
\end{array}$ & $\begin{array}{c}5.00 \\
\pm 0.00 \mathrm{~d}\end{array}$ & $\begin{array}{c}2.92 \\
\pm 0.34 \mathrm{ab}\end{array}$ & $\begin{array}{c}4.75 \\
\pm 0.75 \mathrm{~d} \\
\end{array}$ & \begin{tabular}{|c|}
8.50 \\
$\pm 0.29 \mathrm{e}$ \\
\end{tabular} & 7 & 55.31 & 0.00 \\
\hline & & $5^{\text {th }}$ & $\begin{array}{c}0.92 \\
\pm 0.04 a\end{array}$ & $\begin{array}{c}1.70 \\
\pm 0.12 \mathrm{a}\end{array}$ & 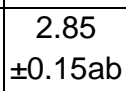 & $\begin{array}{c}3.52 \\
\pm 0.22 \mathrm{bc}\end{array}$ & $\begin{array}{c}4.71 \\
\pm 0.18 \mathrm{c}\end{array}$ & $\begin{array}{c}4.50 \\
\pm 0.58 \mathrm{c}\end{array}$ & $\begin{array}{c}6.36 \\
\pm 0.39 \mathrm{~d}\end{array}$ & \begin{tabular}{|c|}
7.43 \\
$\pm 0.08 \mathrm{~d}$
\end{tabular} & 7 & 63.81 & 0.00 \\
\hline & & $\begin{array}{l}\text { Mean } \\
\text { con. }\end{array}$ & $\begin{array}{c}0.96 \\
\pm 0.02 \mathrm{a}\end{array}$ & $\begin{array}{c}1.74 \\
\pm 0.07 \mathrm{~b}\end{array}$ & $\begin{array}{c}2.93 \\
\pm 0.07 \mathrm{c}\end{array}$ & \begin{tabular}{|c|}
3.74 \\
$\pm 0.07 d$ \\
\end{tabular} & $\begin{array}{c}4.82 \\
\pm 0.10 \mathrm{e}\end{array}$ & $\begin{array}{c}3.89 \\
\pm 0.17 d\end{array}$ & $\begin{array}{c}5.68 \\
\pm 0.21 \mathrm{f}\end{array}$ & \begin{tabular}{|c|}
7.45 \\
$\pm 0.14 \mathrm{~g}$ \\
\end{tabular} & 7 & 304.7 & 0.00 \\
\hline & & $\begin{array}{l}\text { Total } \\
\text { con. }\end{array}$ & $\begin{array}{r}13.00 \\
\pm 1.08 \mathrm{a}\end{array}$ & $\begin{array}{c}19.00 \\
\pm 1.22 \mathrm{a}\end{array}$ & $\begin{array}{c}28.50 \\
\pm 0.87 \mathrm{~b}\end{array}$ & $\begin{array}{c}32.75 \\
\pm 1.11 b\end{array}$ & $\begin{array}{c}42.25 \\
\pm 1.89 \mathrm{c}\end{array}$ & $\begin{array}{c}39.75 \\
\pm 1.25 \mathrm{bc}\end{array}$ & $\begin{array}{c}55.25 \\
\pm 3.47 \mathrm{~d}\end{array}$ & $\begin{array}{c}65.25 \\
\pm 2.43 \mathrm{e}\end{array}$ & 7 & 88.88 & 0.00 \\
\hline
\end{tabular}

* Significance level within the same rows by ANOVA

Means ( \pm SE) in a row followed by the same letters indicate no significant differences and different letters indicate significant differences between prey densities (ANOVA,Bonferroi adjustment) 
Appendix 3. Consumption (\%) of Eocanthecona furcellata (EO) nymphs feb with eight different prey density and reared at three different temperatures

\begin{tabular}{|c|c|c|c|c|c|c|c|c|c|c|c|c|c|}
\hline \multirow[t]{2}{*}{ Tem: } & \multirow[t]{2}{*}{$\begin{array}{c}\text { Function } \\
s \text { of EO }\end{array}$} & \multirow[t]{2}{*}{$\begin{array}{c}\text { EO } \\
\text { Instar }\end{array}$} & \multicolumn{8}{|c|}{$\begin{array}{l}\text { Prey Density } \\
\text { ( DBM larvae) }\end{array}$} & \multirow[t]{2}{*}{ df } & \multirow[t]{2}{*}{$\begin{array}{l}\text { F- } \\
\text { ratio }\end{array}$} & \multirow[t]{2}{*}{$\mathbf{P}^{*}$} \\
\hline & & & 1 & 2 & 3 & 4 & 5 & 6 & 8 & 10 & & & \\
\hline \multirow[t]{5}{*}{$25^{\circ} \mathrm{C}$} & \multirow[t]{5}{*}{$\begin{array}{l}\text { Predation } \\
(\%)\end{array}$} & $2^{\text {nd }}$ & $\begin{array}{r}96.43 \\
\pm 3.57 \mathrm{a}\end{array}$ & $\begin{array}{r}78.75 \\
\pm 4.27 \mathrm{a}\end{array}$ & $\begin{array}{r}81.94 \\
\pm 7.03 a\end{array}$ & $\begin{array}{r}79.58 \\
\pm 4.43 a\end{array}$ & $\begin{array}{r}80.83 \\
\pm 4.33 \mathrm{a}\end{array}$ & $\begin{array}{r}40.97 \\
\pm 5.24 \mathrm{~b}\end{array}$ & $\begin{array}{r}38.54 \\
\pm 1.99 \mathrm{~b} \\
\end{array}$ & $\begin{array}{r}40.83 \\
\pm 1.60 \mathrm{~b}\end{array}$ & 7 & 28.34 & 0.000 \\
\hline & & $3^{\text {rd }}$ & $\begin{array}{r}95.00 \\
\pm 5.00 \mathrm{a}\end{array}$ & $\begin{array}{r}86.04 \\
\pm 7.00 \mathrm{a} \\
\end{array}$ & $\begin{array}{r}94.44 \\
\pm 5.56 \mathrm{a}\end{array}$ & $\begin{array}{r}98.44 \\
\pm 1.56 \mathrm{a}\end{array}$ & $\begin{array}{r}97.50 \\
\pm 1.44 \mathrm{a}\end{array}$ & $\begin{array}{r}38.54 \\
\pm 2.29 \mathrm{~b}\end{array}$ & $\begin{array}{r}44.27 \\
\pm 4.11 \mathrm{~b} \\
\end{array}$ & $\begin{array}{r}42.50 \\
\pm 4.38 \mathrm{~b}\end{array}$ & 7 & 40.05 & 0.000 \\
\hline & & $4^{\text {th }}$ & $\begin{array}{r}100.0 \\
\pm 0.00 \mathrm{a}\end{array}$ & $\begin{array}{r}81.25 \\
\pm 3.61 \mathrm{a}\end{array}$ & $\begin{array}{r}89.17 \\
\pm 3.08 \mathrm{a}\end{array}$ & $\begin{array}{r}81.25 \\
\pm 3.61 \mathrm{a}\end{array}$ & $\begin{array}{r}78.25 \\
\pm 6.30 \mathrm{a}\end{array}$ & $\begin{array}{r}65.28 \\
\pm 5.73 \mathrm{~b}\end{array}$ & $\begin{array}{r}75.00 \\
\pm 7.80 \mathrm{~b} \\
\end{array}$ & $\begin{array}{r}60.00 \\
\pm 3.85 \mathrm{~b}\end{array}$ & 7 & 7.111 & 0.000 \\
\hline & & $5^{\text {th }}$ & $\begin{array}{r}100.0 \\
\pm 0.00 \mathrm{a}\end{array}$ & $\begin{array}{r}96.43 \\
\pm 3.57 \mathrm{a}\end{array}$ & $\begin{array}{r}84.72 \\
\pm 6.16 \mathrm{a}\end{array}$ & $\begin{array}{r}82.29 \\
\pm 5.48 \mathrm{a}\end{array}$ & $\begin{array}{r}80.00 \\
\pm 3.1 \mathrm{ab}\end{array}$ & $\begin{array}{r}85.71 \\
\pm 1.68 \mathrm{a}\end{array}$ & \begin{tabular}{|r|}
83.93 \\
$\pm 1.63 a$ \\
\end{tabular} & $\begin{array}{r}84.64 \\
\pm 2.70 a \\
\end{array}$ & 7 & 9 & .006 \\
\hline & & Mean & $\begin{array}{r}97.67 \\
\pm 1.34 \mathrm{a}\end{array}$ & $\begin{array}{r}86.79 \\
\pm 1.28 \mathrm{~b}\end{array}$ & $\begin{array}{r}87.72 \\
\pm 3.72 \mathrm{~b}\end{array}$ & $\begin{array}{r}84.14 \\
\pm 0.71 b\end{array}$ & $\begin{array}{r}83.78 \\
\pm 2.00 \mathrm{~b} \\
\end{array}$ & $\begin{array}{r}64.57 \\
\pm 1.64 \mathrm{c}\end{array}$ & $\begin{array}{r}66.50 \\
\pm 1.63 \mathrm{c} \\
\end{array}$ & $\begin{array}{r}63.91 \\
\pm 1.77 \mathrm{c} \\
\end{array}$ & 7 & 2.47 & .000 \\
\hline \multirow[t]{5}{*}{$30^{\circ} \mathrm{C}$} & \multirow[t]{5}{*}{$\begin{array}{l}\text { Predation } \\
\text { (\%) }\end{array}$} & $2^{\text {nd }}$ & $\begin{array}{r}100.0 \\
\pm 0.00 \mathrm{a}\end{array}$ & $\begin{array}{r}68.75 \\
\pm 11.9 a\end{array}$ & $\begin{array}{r}75.00 \\
\pm 15.9 \mathrm{a}\end{array}$ & $\begin{array}{r}81.25 \\
\pm 6.25 \mathrm{a}\end{array}$ & $\begin{array}{r}75.00 \\
\pm 5.00 \mathrm{a}\end{array}$ & $\begin{array}{r}93.75 \\
\pm 3.99 \mathrm{a}\end{array}$ & $\begin{array}{r}50.00 \\
\pm 2.5 \mathrm{ab} \\
\end{array}$ & $\begin{array}{r}58.75 \\
\pm 7.5 \mathrm{ab}\end{array}$ & 7 & 4.112 & 0.004 \\
\hline & & $3^{\text {rd }}$ & $\begin{array}{r}100.0 \\
\pm 0.00 \mathrm{a} \\
\end{array}$ & $\begin{array}{r}95.83 \\
\pm 4.17 \mathrm{a} \\
\end{array}$ & $\begin{array}{r}100.0 \\
\pm 0.00 \mathrm{a} \\
\end{array}$ & $\begin{array}{r}90.63 \\
\pm 5.9 \mathrm{ab} \\
\end{array}$ & $\begin{array}{r}86.67 \\
\pm 6.1 \mathrm{ab} \\
\end{array}$ & $\begin{array}{r}91.67 \\
\pm 8.33 \mathrm{a} \\
\end{array}$ & $\begin{array}{r}64.06 \\
\pm 6.44 \mathrm{~b} \\
\end{array}$ & $\begin{array}{r}65.63 \\
\pm 4.83 \mathrm{~b} \\
\end{array}$ & 7 & 7.057 & 0.000 \\
\hline & & $4^{\text {th }}$ & $\begin{array}{r}100.0 \\
\pm 0.00 \mathrm{a}\end{array}$ & $\begin{array}{r}100.0 \\
\pm 0.00 \mathrm{a} \\
\end{array}$ & $\begin{array}{r}95.42 \\
\pm 2.67 \mathrm{a} \\
\end{array}$ & $\begin{array}{r}97.92 \\
\pm 2.08 \mathrm{a} \\
\end{array}$ & $\begin{array}{r}100.0 \\
\pm 0.00 \mathrm{a}\end{array}$ & $\begin{array}{r}86.11 \\
\pm 2.78 \mathrm{a}\end{array}$ & $\begin{array}{r}73.43 \\
\pm 2.31 \mathrm{~b} \\
\end{array}$ & $\begin{array}{r}75.42 \\
\pm 8.32 \mathrm{~b} \\
\end{array}$ & 7 & 10.80 & 0.000 \\
\hline & & $5^{\text {th }}$ & $\begin{array}{r}100.0 \\
\pm 0.00 \mathrm{a}\end{array}$ & $\begin{array}{r}93.75 \\
\pm 3.99 \mathrm{a} \\
\end{array}$ & $\begin{array}{r}89.17 \\
\pm 3.70 \mathrm{a}\end{array}$ & $\begin{array}{r}79.06 \\
\pm 2.5 \mathrm{ab} \\
\end{array}$ & $\begin{array}{r}82.50 \\
\pm 1.4 \mathrm{ab} \\
\end{array}$ & $\begin{array}{r}88.54 \\
\pm 7.09 \mathrm{a} \\
\end{array}$ & $\begin{array}{r}81.25 \\
\pm 2.6 \mathrm{ab} \\
\end{array}$ & $\begin{array}{r}96.46 \\
\pm 1.46 \mathrm{a} \\
\end{array}$ & 7 & 4.733 & 0.002 \\
\hline & & Mea & $\begin{array}{l}100.0 \pm \\
0.00 \mathrm{a}\end{array}$ & $\begin{array}{r}91.55 \\
\pm 2.49 \mathrm{a}\end{array}$ & $\begin{array}{r}90.31 \\
\pm 4.08 \mathrm{a}\end{array}$ & $\begin{array}{r}86.82 \\
\pm 1.4 \mathrm{ab}\end{array}$ & $\begin{array}{r}86.86 \\
\pm 1.3 \mathrm{ab}\end{array}$ & $\begin{array}{r}88.80 \\
\pm 3.51 \mathrm{a}\end{array}$ & $\begin{array}{r}71.28 \\
\pm 2.13 \mathrm{c}\end{array}$ & $\begin{array}{r}76.31 \\
\pm 3.58 \mathrm{c}\end{array}$ & 7 & 11.45 & 0.000 \\
\hline \multirow[t]{5}{*}{$35^{\circ} \mathrm{C}$} & \multirow[t]{5}{*}{$\begin{array}{l}\text { Predation } \\
\text { (\%) }\end{array}$} & $2^{\text {nd }}$ & $\begin{array}{r}100.0 \\
\pm 0.00 \mathrm{a} \\
\end{array}$ & $\begin{array}{r}62.50 \\
\pm 12.5 \mathrm{~b} \\
\end{array}$ & $\begin{array}{r}100.0 \\
\pm 0.00 \mathrm{a} \\
\end{array}$ & $\begin{array}{r}93.75 \\
\pm 6.25 \mathrm{a} \\
\end{array}$ & $\begin{array}{r}100.0 \\
\pm 0.00 \mathrm{a} \\
\end{array}$ & $\begin{array}{r}79.17 \\
\pm 7.9 \mathrm{ab} \\
\end{array}$ & $\begin{array}{r}76.56 \\
\pm 3.9 \mathrm{ab} \\
\end{array}$ & $\begin{array}{r}65.50 \\
\pm 4.79 \mathrm{~b} \\
\end{array}$ & 7 & 6.416 & 0.000 \\
\hline & & $3^{\text {rd }}$ & $\begin{array}{r}100.0 \\
\pm 0.00 \mathrm{a}\end{array}$ & $\begin{array}{r}100.0 \\
\pm 0.00 \mathrm{a} \\
\end{array}$ & $\begin{array}{r}100.0 \\
\pm 0.00 \mathrm{a} \\
\end{array}$ & $\begin{array}{r}96.88 \\
\pm 3.13 \mathrm{a} \\
\end{array}$ & $\begin{array}{r}95.00 \\
\pm 5.00 \mathrm{a} \\
\end{array}$ & $\begin{array}{r}56.25 \\
\pm 3.99 \mathrm{~b} \\
\end{array}$ & $\begin{array}{r}73.44 \\
\pm 9.67 \mathrm{~b} \\
\end{array}$ & $\begin{array}{r}66.25 \\
\pm 2.39 \mathrm{~b} \\
\end{array}$ & 7 & 16.92 & 0.000 \\
\hline & & $4^{\text {th }}$ & $\begin{array}{r}100.0 \\
\pm 0.00 \mathrm{a}\end{array}$ & $\begin{array}{r}89.58 \\
\pm 6.25 \mathrm{a}\end{array}$ & $\begin{array}{r}100.0 \\
\pm 0.00 \mathrm{a}\end{array}$ & $\begin{array}{r}100.0 \\
\pm 0.00 \mathrm{a}\end{array}$ & $\begin{array}{r}100.0 \\
\pm 0.00 \mathrm{a}\end{array}$ & $\begin{array}{r}48.61 \\
\pm 5.73 b\end{array}$ & $\begin{array}{r}59.38 \\
\pm 9.38 b\end{array}$ & $\begin{array}{r}67.00 \\
\pm 2.89 \mathrm{~b}\end{array}$ & 7 & 19.73 & 0.000 \\
\hline & & $5^{\text {th }}$ & $\begin{array}{r}92.26 \\
\pm 4.49 \mathrm{a}\end{array}$ & $\begin{array}{r}85.00 \\
\pm 6.12 \mathrm{a} \\
\end{array}$ & $\begin{array}{r}95.00 \\
\pm 5.00 \mathrm{a}\end{array}$ & $\begin{array}{r}88.02 \\
\pm 5.54 \mathrm{a}\end{array}$ & $\begin{array}{r}94.25 \\
\pm 3.61 \mathrm{a}\end{array}$ & $\begin{array}{r}75.00 \\
\pm 9.67 \mathrm{a}\end{array}$ & $\begin{array}{r}79.53 \\
\pm 4.88 \mathrm{a}\end{array}$ & $\begin{array}{r}74.25 \\
\pm 0.75 \mathrm{a} \\
\end{array}$ & 7 & 2.300 & 0.061 \\
\hline & & n & $\begin{array}{r}96.13 \\
\pm 2.25 \mathrm{a} \\
\end{array}$ & $\begin{array}{r}87.23 \\
\pm 3.48 \mathrm{a} \\
\end{array}$ & $\begin{array}{r}97.73 \\
\pm 2.27 \mathrm{a} \\
\end{array}$ & $\begin{array}{r}93.58 \\
\pm 1.73 \mathrm{a} \\
\end{array}$ & $\begin{array}{r}96.46 \\
\pm 2.05 \mathrm{a} \\
\end{array}$ & $\begin{array}{r}64.77 \\
\pm 2.78 \mathrm{~b} \\
\end{array}$ & $\begin{array}{r}71.04 \\
\pm 2.59 \mathrm{~b} \\
\end{array}$ & $\begin{array}{r}74.55 \\
\pm 1.41 \mathrm{~b} \\
\end{array}$ & 7 & 30.04 & 0.000 \\
\hline
\end{tabular}

* Significance level within the same rows by ANOVA

Means ( \pm SE) in a row followed by the same letters indicate no significant differences and different letters indicate significant differences between prey densities (ANOVA,Bonferroi adjustment) 
Appendix 4

Potential for biocontrol of the Diamondback Moth in Myanmar by using a predatory bug

KHIN THEIN NYUNT, STEFAN VIDAL

Georg-August-University Göttingen, Department of Crop Sciences, Entomological Section, Germany

The Diamondback Moth (DBM) is most damaging vegetable pest not only in Myanmar than also in most tropical countries, where cabbage plants and ideal temperatures for high DBM populations prevail throughout the year. Due to frequent insecticide applications development of resistance towards specific compounds, including Bacillus thuringiensis, has been reported in several regions. We tested a predatory bug (Eocanthecona furcellata - EO), native to Myanmar and commonly found in the field, for its effectiveness to prey on DBM.

We used $2^{\text {nd }}$ instars of EO nymphs and 5 different DBM larval densities. DBM larvae were placed in $9 \mathrm{~cm} \varnothing$ plastic petri dishes and one EO nymph was placed in the center of each arena; these were then kept at a constant temperature $\left(30^{\circ} \mathrm{C}, 75 \% \mathrm{RH}\right.$ and 12:12 L:D) photoperiod in climate cabinets. Larvae consumed per day, larvae still alive and molting date were recorded to adult stage of EO.

The maximum prey consumption per day per EO larvae was surprisingly high and exceeded $9.65( \pm 0.29)$ larvae at $30^{\circ} \mathrm{C}$ in the $5^{\text {th }}$ instar of EO. During the whole lifecycle $\left(2^{\text {nd }}\right.$ instars to adult), EO was able to consume between $25.50 \pm 2.89$ (minimum) and $70.5 \pm 6.35$ (maximum) DBM larvae. EO larvae did feed on different lepidopteran species; however, they refused to feed on aphids.

Base on these preliminary data we recommend that the predatory bug Eocanthecona furcellata should be tested under field conditions as a biocontrol agent for controlling diamondback moth in Myanmar. Additional research is now done to understand the host spectrum and the ecology of this species.

Keywords: biological control, Diamondback Moth, Eocanthecona furcellata, Myanmar, predatory bug,

Contact Address: Khin Thein Nyunt, Georg-August-University Göttingen, Department of Crop Sciences, Entomological Section, Grisebachstr.6, 37077 Göttingen, Germany, e-mail: knyunt@gwdg.de 


\title{
Potential for Biocontrol of Diamondback Moth in Myanmar by using a predatory bug
}

\author{
Khin Thein Nyunt and Stefan Vidal \\ Georg-August-University Goettingen, Department of Crop Science, \\ Entomology Section, Germany
}

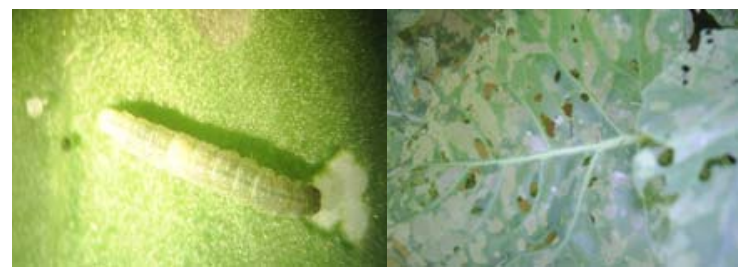

\section{Introduction}

a Diamondback Moth (DBM) is most damaging vegetable pest not only in Myanmar than also in most tropical countries

- cabbage plants and ideal temperatures for high DBM populations prevail throughout the year

* Due to frequent insecticide applications development of resistance including B.thuringiensis

\section{Hypothesis}

- We tested a predator bug (Eocanthecona furcellata- EO), native to Myanmar and commonly found in the field, for its effectiveness to prey on Diamondback Moth

\section{Methods}

$\Rightarrow$ 2nd instars of EO nymphs and 5 different DBM larval densities $(2,4,6,8,10)$ were used for this experiment.

$\Rightarrow$ DBM larvae were placed in $9 \mathrm{~cm} \varnothing$ plastic petri dishes and one EO nymph was placed in the centre of each arena; these were then kept at a constant temperature (30_C, 75\% RH and 12:12 L:D) photoperiod in climate cabinets.

- Larvae consumed per day, larvae still alive and molting date were recorded to adult stage of EO.

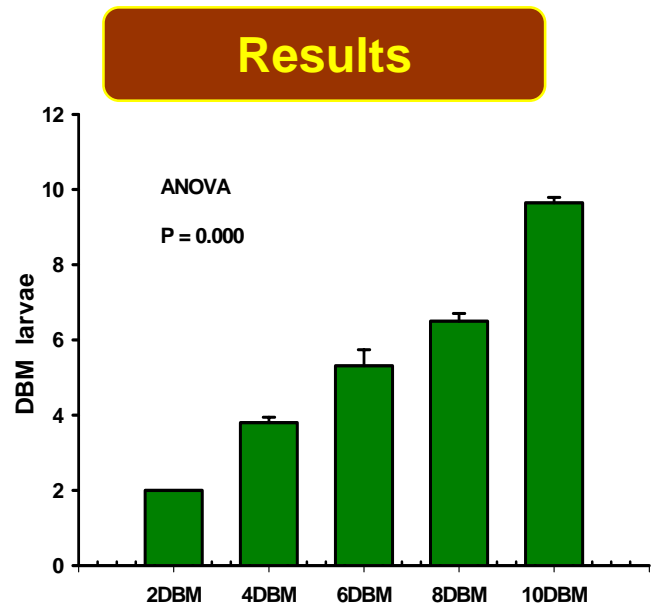

Fig 1. Amount of DBMlarvae daily consumed by E.furcellata
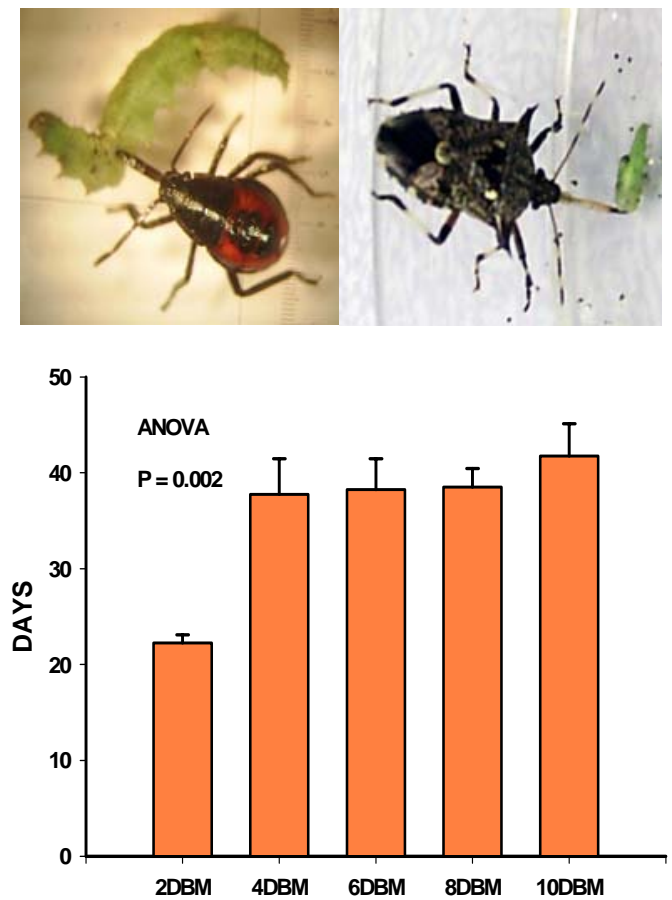

Fig 2. Logevity of Eocanthecona furcellata

\section{Conclusion}

Base on these preliminary data we recommend that the predatory bug Eocanthecona furcellata should be tested under field conditions as a biocontrol agent for controlling diamondback moth in Myanmar 
Appendix 5

Predatory potential of the pentatomid stink bug Eocanthecona furcellata at different temperature regimes

\author{
Khin Thein NyUnt, Stefan Vidal
}

\title{
Georg- August University, Department of Crop Sciences, Agricultural Entomology Section, Goettingen (Email: knyunt@gwdg.de)
}

The predatory stink bug Eocanthecona furcellata Wolff (Hemiptera: Pentatomidae - EO), native to Southeast Asia offers potential to be used as a biological control agent against lepidopteran pests. However, in order to establish mass rearing methods the life history of EO has to be evaluated in detail. We investigated the effect of extreme temperature regimes on the development, fecundity and predation rate of the bug using Diamondback Moth larvae (DBM) Plutella xylostella L. (Lepidoptera: Yponomeutidae) under laboratory conditions EOs were reared at constant temperatures $\left(15,20,37\right.$, and $40^{\circ} \mathrm{C}$, respectively) in climatic cabinets at 75\% RH and 12:12 (L:D) photoperiod. $2^{\text {nd }}$ instars of EO nymphs were used in the experiments and DBM larvae consumed per day, EO larvae still alive, molting date and oviposition dates of adults were recorded.

The longest developmental time of EO from egg to adult was obtained at $20^{\circ} \mathrm{C}(116.00 \pm$ 1.14) days, while EO did not develop at $40^{\circ} \mathrm{C}$. The maximum prey consumption per day per adult EO was very high and was on average 23.1 \pm 0.6 DBM larvae during the whole lifecycle $\left(2^{\text {nd }}\right.$ instars to adult). One individual consumed up to $388.9 \pm 8.2 \mathrm{DBM}$ larvae at $37^{\circ} \mathrm{C}$. EO females deposited on average $14.8 \pm 3.2$ eggs per batch at $37^{\circ} \mathrm{C}$, but these eggs failed to begin embryonic development.

Our data suggest that EO is adapted to climatic conditions prevailing in the tropical regions and may be used for biological control purposed only in areas with mean temperatures above $25^{\circ} \mathrm{C}$.

Key words: biological control, development, extreme temperatures, fecundity 


\section{Predatory potential of the Pentatomid stink bug Eocanthecona furcellata at different temperature regimes}

\section{Khin Thein Nyunt and Stefan Vidal}

Georg-August-University Goettingen, Department of Crop Science,
Entomology Section, Germany

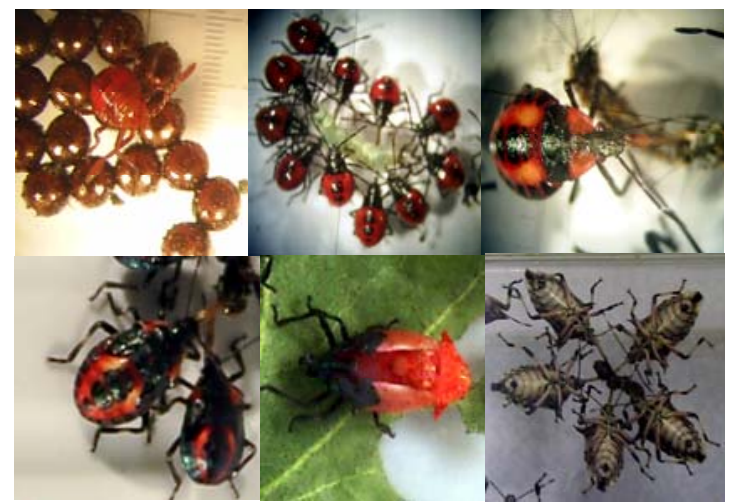

Eocanthecona furcellata (Wolff)

\section{Introduction}

$>$ The predatory stink bug Eocanthecona furcellata Wolff (Hemiptera: Pentatomidae - EO), native to South-east Asia, offers potential to be used as a biological control agent against lepidopteran pests

> The life history of EO has to be evaluated in detail for establishing mass rearing methods

\section{Hypothesis}

$>$ We investigated the effect of extreme temperature regimes on the development, fecundity and predation rate of the bug using Diamondback Moth larvae (DBM) Plutella xylostella L. (Lepidoptera: Yponomeutidae) under laboratory conditions

\section{Methods}

$>$ We used 2nd instars of EO nymphs in the experiments

$>$ DBM larvae were placed in $9 \mathrm{~cm} \varnothing$ Petri-dishes; one EO nymph was placed in the centre of each arena; these were then kept at constant temperatures $(15,20$, 37 , and $40^{\circ} \mathrm{C}$, respectively) in climatic cabinets at $75 \%$ $\mathrm{RH}$ and 12:12 (L:D) photoperiod

$>$ DBM larvae consumed per day, EO larvae still alive , moulting dates and oviposition dates of the adults were recorded

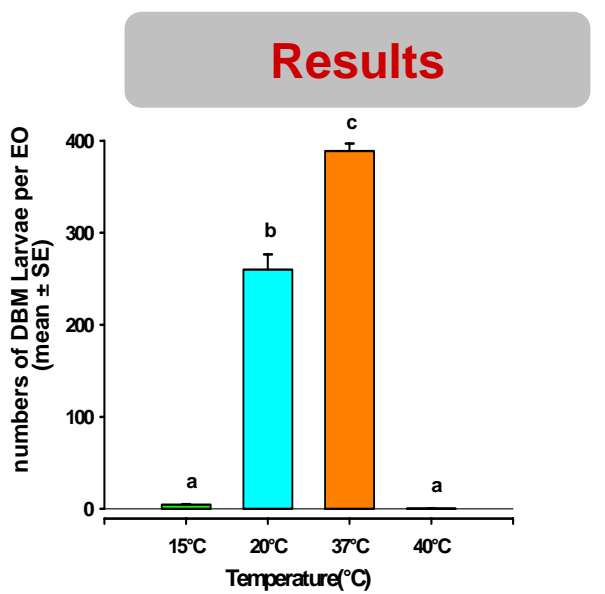

Fig 1 Effect of temperatur on total prey consumption of EO significantly differed at $P=0.01$ (Bonferroni)

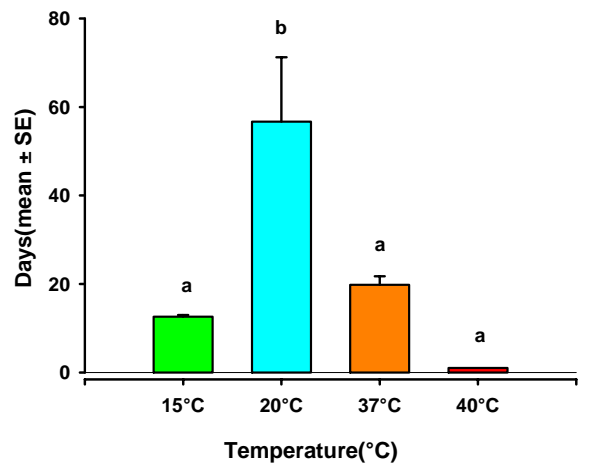

Fig. 2. Effect of temperatur on longevity of EO (from $2^{\text {nd }}$ instar to death) significantly differed at $P=0.01$ (Bonferroni)

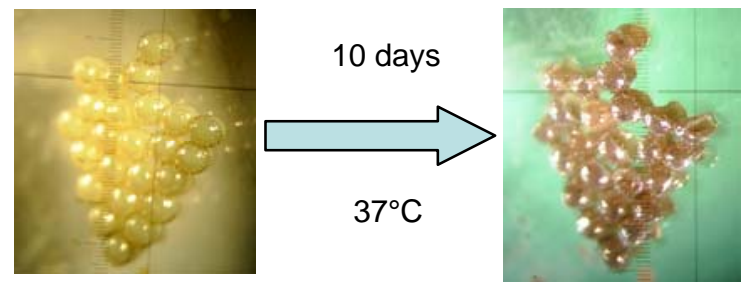

Fig. 3. EO eggs failed to begin embryonic development at $37^{\circ} \mathrm{C}$

\section{Conclusion}

EO is unable to produce viable offspring at constant temperatures below $20^{\circ} \mathrm{C}$ or above $37^{\circ} \mathrm{C}$

$>$ EO seems to be adapted to climatic conditions prevailing in the tropical regions

$>$ Thus it may be used for biological control purposed only in areas with mean temperatures of above $25^{\circ} \mathrm{C}$

\section{Acknowledgement}

Special thanks to the Gottlieb Daimler and Karl Benz Foundation for supporting this work 
Appendix 6

Predation efficiency of Eocanthecona furcellata on Helicoverpa armigera larvae reared on different host plants

KHIN THEIN NYUNT, STEFAN VIDAL

Georg-August-University Göttingen, Department of Crop Sciences, Entomological Section, Germany

The predatory pentatomid bug Eocanthecona furcellata (Wolff) (EO) is regarded a potential biological control agent against lepidopteran pests in Southeast Asia. We investigated the predation efficiency of EO with regard to the noctuid Helicoverpa armigera (Hübner) (ABW), which is a highly polyphagous agricultural pest, especially in cotton, chickpea and tomato in Myanmar. Specifically, we tested the influence of larval feeding reared on different host plants (cotton, cabbage, chickpea and tomato plants) or artificial diet on bug predation.

In each experiment ten males and females EO adults were used, which were starved for 24 hours before the experiment. ABW larvae were fixed with tape and placed randomly in small plastic boxes before transferring ten EO adults to the center of the arena. In a second series ABW larvae and their faeces were wrapped with Para film and also tested the same way. Movement of EO was recorded at room temperature.

EO adults preferred to prey on ABW larvae reared on cotton plants (42\%); ABW larvae from cabbage, chickpea and tomato plants were accepted less as prey. ABW larvae fed on artificial diet were not accepted as prey (1\%). 13\% of EO were not actively searching for hosts; however in the experiment with wrapped ABW larvae 38\% were not active, and predation on ABW larvae from cotton was reduced to $25 \%$. Adding faeces to the larvae did not result in higher predation rates by EO.

Base on these data we recommend to release the predatory bug Eocanthecona furcellata in cotton fields as a biocontrol agent for controlling Helicoverpa armigera in Myanmar.

Keywords: biological control agent, cabbage, chickpea, cotton, Eocanthecona furcellata, Helicoverpa armigera, Myanmar, predatory bug,

Contact Address: Khin Thein Nyunt, Georg-August-University Göttingen, Department of Crop Sciences, Entomological Section, Grisebachstr.6, 37077 Göttingen, Germany, e-mail: knyunt@gwdg.de 


\title{
Predation efficiency of Eocanthecona furcellata on Helicoverpa armigera larvae reared on different host plants
}

\author{
Khin Thein Nyunt and Stefan Vidal \\ Georg-August-University Goettingen, Department of Crop Science, \\ Entomological Section, Germany
}
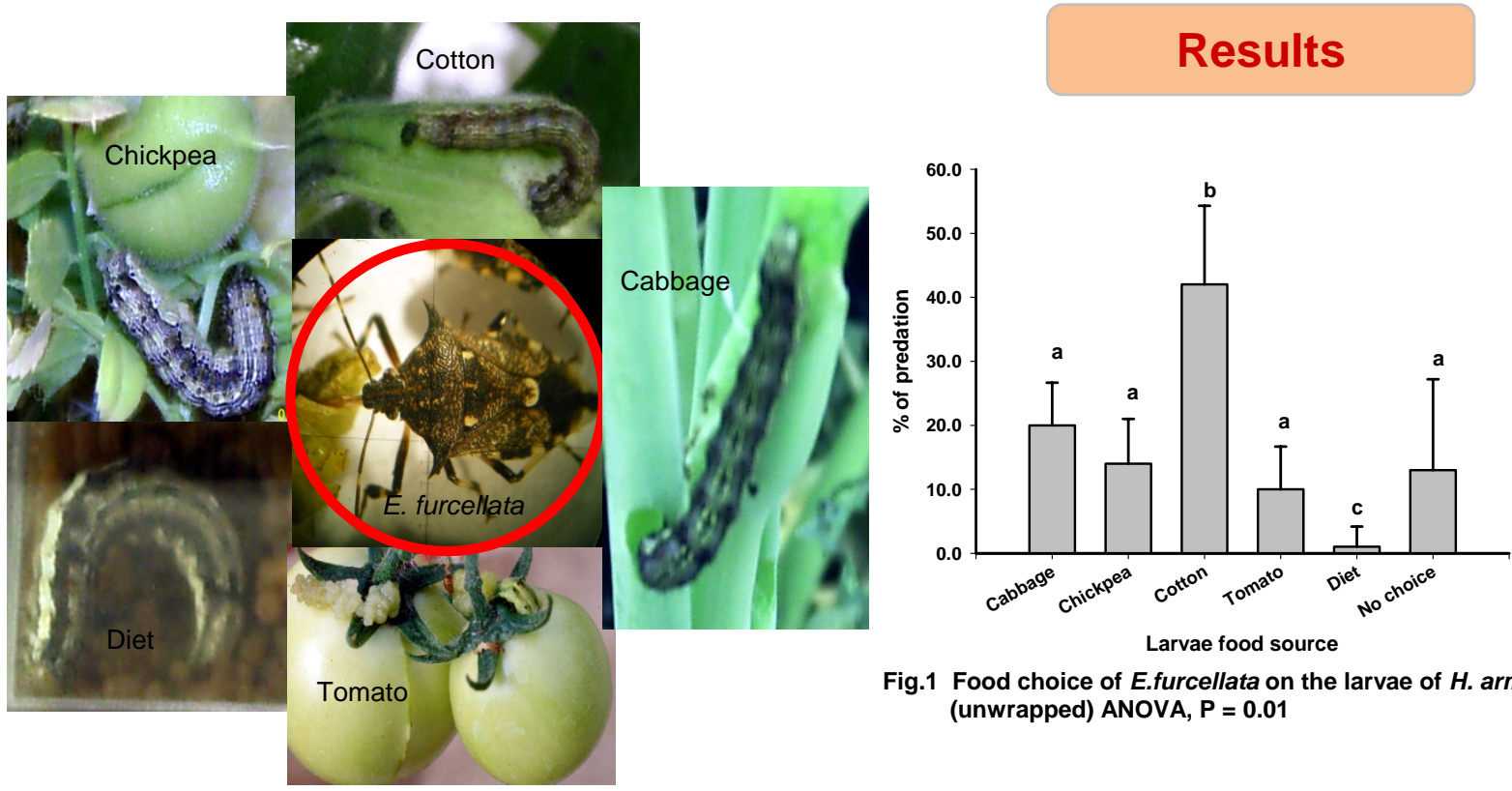

Fig.1 Food choice of E.furcellata on the larvae of $\boldsymbol{H}$. armigera (unwrapped) ANOVA, $P=0.01$

\section{Introduction}

- The predatory pentatomid bug Eocanthecona furcellata (Wolff) (EO) is regarded a potential biological control agent against lepidopteran pests in Southeast Asia

จ The noctuid Helicoverpa armigera (Hübner) (ABW) is a highly polyphagous agricultural pest, especially in cotton, chickpea and tomato in Myanmar

\section{Hypothesis}

\oth larval feeding on different host plants (cotton, cabbage chickpea or tomato plants) or an artificial diet will influence acceptance of the larvae by the bug EO

\section{Methods}

We used ten starved male and female EO adults per experiment

○ ABW larvae were fixed with tape and placed randomly in small plastic boxes; ten EO adults were transferred in the centre of each arena

- In a second series ABW larvae and their faeces were wrapped with Para film and tested as mentioned above

- Prey selection behavior of EO adults was recorded at room temperature

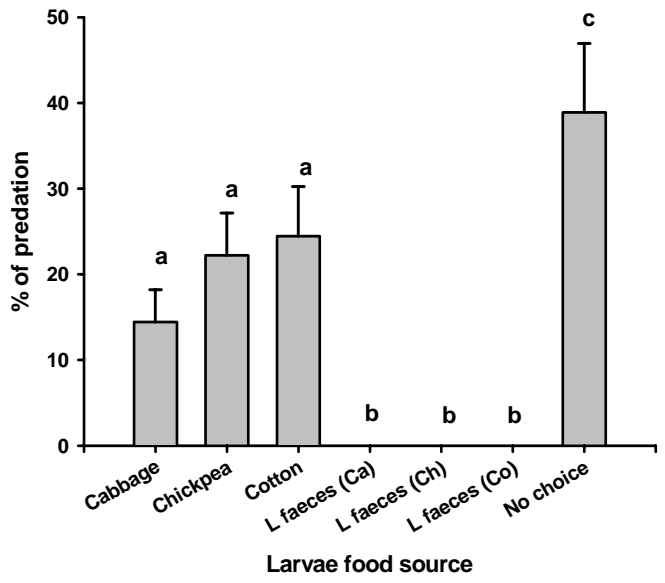

Fig. 2 Food choice of E.furcellata on the larvae of $H$. armigera (wrapped) ANOVA, $P=0.01$

\section{Conclusion}

- EO adults preferred to prey on ABW larvae reared on cotton plants in both experiments

- Based on these data we recommend to release the predatory bug Eocanthecona furcellata in cotton fields as a biocontrol agent for controlling Helicoverpa armigera in Myanmar

\section{Acknowledgement}

- Special thanks to the Gottlieb Daimler and Karl Benz Foundation for supporting this work 
